\title{
Capturing the Patient's Voice
}

Citation for published version (APA):

Draak, T. H. P. (2019). Capturing the Patient's Voice: Peripheral Neuropathy outcome measures Standardisation (PeriNomS) study part 3. [Doctoral Thesis, Maastricht University]. ProefschriftMaken Maastricht. https://doi.org/10.26481/dis.20190621td

\section{Document status and date:}

Published: 01/01/2019

DOI:

10.26481/dis.20190621td

Document Version:

Publisher's PDF, also known as Version of record

\section{Please check the document version of this publication:}

- A submitted manuscript is the version of the article upon submission and before peer-review. There can be important differences between the submitted version and the official published version of record.

People interested in the research are advised to contact the author for the final version of the publication, or visit the DOI to the publisher's website.

- The final author version and the galley proof are versions of the publication after peer review.

- The final published version features the final layout of the paper including the volume, issue and page numbers.

Link to publication

\footnotetext{
General rights rights.

- You may freely distribute the URL identifying the publication in the public portal. please follow below link for the End User Agreement:

www.umlib.nl/taverne-license

Take down policy

If you believe that this document breaches copyright please contact us at:

repository@maastrichtuniversity.nl

providing details and we will investigate your claim.
}

Copyright and moral rights for the publications made accessible in the public portal are retained by the authors and/or other copyright owners and it is a condition of accessing publications that users recognise and abide by the legal requirements associated with these

- Users may download and print one copy of any publication from the public portal for the purpose of private study or research.

- You may not further distribute the material or use it for any profit-making activity or commercial gain

If the publication is distributed under the terms of Article $25 \mathrm{fa}$ of the Dutch Copyright Act, indicated by the "Taverne" license above, 
Capturing the Patient's Voice

Peripheral Neuropathy outcome measures Standardisation (PeriNomS) study part 3

(C) T.H.P. Draak, Maastricht, 2019

ISBN/EAN: 978-94-6380-378-6

Design and lay-out: Wendy Schoneveld \|| www.wenzid.nl Printed: ProefschiftMaken || Proefschiftmaken.nl

This research project was financially supported (grants) by GBS/CIDP International Foundation, USA and Talents programm of Talecris industry, USA, now part of Grifols. 


\section{Capturing the Patient's Voice}

Peripheral Neuropathy outcome measures Standardisation (PeriNomS) study part 3

\section{PROEFSCHRIFT}

ter verkrijging van de graad van doctor

aan de Universiteit Maastricht,

op gezag van Rector Magnificus, Prof. dr. Rianne M. Letschert

volgens het besluit van het college van Decanen,

in het openbaar te verdedigen op

vrijdag 21 juni 2019 om 12.00 uur

door

Thomas Hubertus Peter Draak 


\section{Promotor}

Prof. dr. C.G. Faber

\section{Co-promotor}

Dr. I.S.J. Merkies

\section{Beoordelingscommissie}

Prof. dr. R.J. Vermeulen (voorzitter)

Prof. dr. P.Y. van den Bergh (Brussel)

Prof. dr. W.H. Mess

Prof. dr. I.N. van Schaik (Amsterdam)

Mw. prof. dr. A.M.C.F. Verbunt 


\section{Table of contents}

CHAPTER 1 General introduction and outline of thesis

1.1 Inflammatory neuropathies: clinical aspects summarized 8

1.2 Outcome measures: a Rasch point of view 9

1.3 The Peripheral Neuropathy outcome Measures 12 Standardization (PeriNomS) study: an introduction and results so far

1.4 Outline of current thesis $\quad 14$

CHAPTER 2 Changing outcome in inflammatory neuropathies: 19

Rasch-comparative responsiveness

CHAPTER 3 Does ability to walk reflect general functionality in 39 inflammatory neuropathies?

CHAPTER 4 Correlation of the patient's reported outcome Inflammatory-

RODS with an objective metric in immune-mediated

neuropathies

CHAPTER 5 Quality of life in inflammatory neuropathies: the IN-QoL

CHAPTER 6 The minimum clinically important difference (MCID):

which direction to take

$\begin{array}{lll}\text { CHAPTER } 7 & \text { General discussion and future perspectives } & 97\end{array}$

$\begin{array}{ll}\text { Summary } & 110\end{array}$

Nederlandse samenvatting $\quad 113$

Valorisation 116

Dankwoord 118

Curriculum Vitae $\quad 121$

List of publications $\quad 122$ 

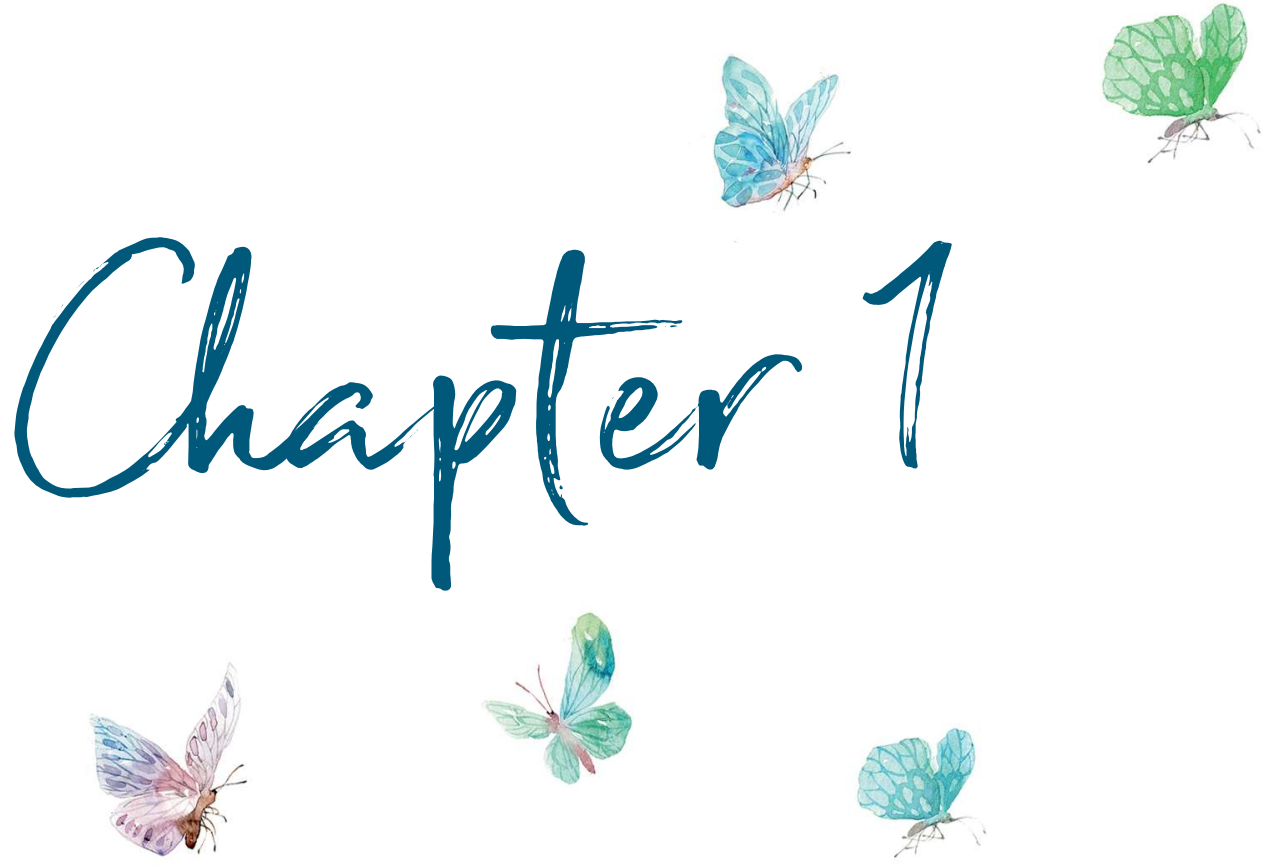


\section{General introduction and outline of the thesis}




\subsection{INFLAMMATORY NEUROPATHIES: CLINICAL ASPECTS SUMMARIZED}

\section{Introduction}

Inflammatory neuropathies: include Guillain-Barré syndrome (GBS), chronic inflammatory demyelinating polyneuropathy (CIDP), monoclonal gammopathy of undetermined significance related polyneuropathy (MGUSP) and multifocal motor neuropathy (MMN).

Here, an overview of the most important clinical aspects (symptoms, prevalence and treatment) will be presented for each illness.

\section{Guillain-Barré syndrome (GBS)}

The Guillain-Barré syndrome (GBS) is the most common cause of an acute flaccid paralysis, with about 100,000 patients developing the disorder every year worldwide, with an incidence of 1-2 cases per 100,000 people per year. (1) In typical GuillainBarré syndrome the presenting symptom is rapidly progressive bilateral weakness with areflexia. Some patients present with cranial nerve involvement, sensory deficits or autonomic dysfunction. The usual disease course is a progressive phase lasting up to 4 weeks and a recovery phase lasting months up to multiple years.

Treatment with intravenous immunoglobulin (IVIg) and plasma exchange are proven to be effective, mainly on motor symptoms in adults with a typical and severe form of GBS. $(2,3)$

Despite these treatment options, around $25 \%$ of the patients will experience respiratory failure and there is a $3-7 \%$ mortality rate. (1)

\section{Chronic inflammatory demyelinating polyneuropathy (CIDP)}

The most common, treatable, chronic neuropathy worldwide is chronic inflammatory demyelinating polyneuropathy (CIDP). It has a prevalence ranging from 1-9 cases per 100.000 patients per year. (4)

It presents as subacute progressive or relapsing neuropathy over a course of at least 8 weeks. There are many phenotypes of CIDP, of which the typical phenotype is symmetrical deficits in both sensory and motor nerve function, both proximal and distal.

More than half of the affected people cannot walk unaided when symptoms are at their worst. CIDP usually responds to immunomodulatory treatment (corticosteroids, immunoglobulin and plasma exchange), but there is no consensus on which treatment is the most effective. (5) Each of these treatments has been demonstrated to be superior to placebo in randomized, double-blind, placebocontrolled studies. Improvement can be expected in $50-80 \%$ of patients with one of the standard treatments. (6) 


\section{Immunoglobulin M-monoclonal gammopathy of undetermined significance related polyneuropathy (MGUSP)}

Monoclonal gammopathies are caused by a proliferation of monoclonal plasma cells or B lymphocytes. They are a heterogenous group of disorders, ranging from subclinical to malignant systemic disorders such as multiple myeloma. The prevalence of monoclonal gammopathy increases with age, occurring in $1 \%$ in healthy individuals over 25 years of age, up to $10 \%$ in those over 80 years of age. The prevalence of monoclonal gammopathy in patients with an idiopathic peripheral neuropathy is around $10 \%$, after adjusting for age. (7)

Patients with IgM-MGUSP are usually males in their $6^{\text {th }}$ to $9^{\text {th }}$ decade of life, with an insidiously progressive, distal, predominantly sensory neuropathy, with mild distal weakness. (7) Tremor and ataxia can also be present.

Patients should have regular haematological evaluation, because malignant transformation occurs at approximately $1.3 \%$ per year.

Immunomodulatory treatment (immunoglobulin, corticosteroids, plasma exchange, Rituximab, cyclophosphamide, fludarabine and chlorambucil) can be considered but are unproven and there is no consensus on which treatment to use first. (8)

\section{Multifocal motor neuropathy (MMN)}

Multifocal motor neuropathy (MMN) has a prevalence of 0.6 cases per 100.000 patients per year. The onset of weakness often starts with wrist drop, grip weakness and foot drop without objective sensory loss. There is a slow or stepwise progressive disease course, with focal, asymmetric limb weakness. There is no cranial nerve involvement and cramps/fasciculations can be present. (9)

Treatment options are limited to immunoglobulin. Immunosuppressive drugs (such as cyclophosphamide, azathioprine and mycophenolate mofetil) have not shown to be effective as initial or add-on treatments. (9-11) MMN does not usually respond to steroids or plasma exchange and patients may worsen when they receive these treatments. (12)

\subsection{OUTCOME MEASURES: A RASCH POINT OF VIEW}

Clinimetrics is a scientific discipline that assesses the properties of health measurement instruments, aiming to improve existing or develop new outcome measurements.

Measuring the clinical state of patients is a fundamental part of our daily clinical practice and research that sometimes has been taken for granted.

There are different levels of data in measurements (nominal, ordinal, interval, and ratio data). (13)

- Nominal data is used for classification, for example gender or nationality. 
- Ordinal data is used for comparison allowing rank order, for example $1^{\text {st }}, 2^{\text {nd }}$ and $3^{\text {rd }}$ or a Likert-scale ('strongly disagree' up to 'strongly agree'), in which there is no relative or set degree of difference between these measurements.

- Interval data has a set degree of difference between its items, for example temperature in the Celsius scale $\left({ }^{\circ} \mathrm{C}\right)$. There are two defined points $\left(0{ }^{\circ} \mathrm{C}\right.$ for freezing, $100{ }^{\circ} \mathrm{C}$ for boiling) with 100 intervals in between those set points, which are proportionate with each other.

- Ratio data is data with a continuous quantity with a unique, non-arbitrary zero value. Examples are mass and length.

For a visual representation, see Figure 1.

Nominal and ordinal data are so-called 'qualitative data'. Interval and ratio data are so-called 'quantitative data'.

Most outcome measures in modern medicine are ordinal-based, which allow for placing the items of interest in a certain order. However, usually by applying numbers to the order created, clinicians and researchers alike are tempted into creating sumscores of ordinal data and treat these scores as linear. Conventional statistics (e.g. t-testing) can only be applied to interval or ratio data. These imperfections can lead to making false assumptions and drawing incorrect conclusions of the data, resulting in false positive or false negative trial results.

Over time, mathematical models to create outcome measures have been developed. The Classical Test Theory (CTT) is the most widely used model, based on the assumption that the true score is the sum of the obtained score (raw data) and random error. $(14,15)$ The CTT is concerned with the relationship between these variables,

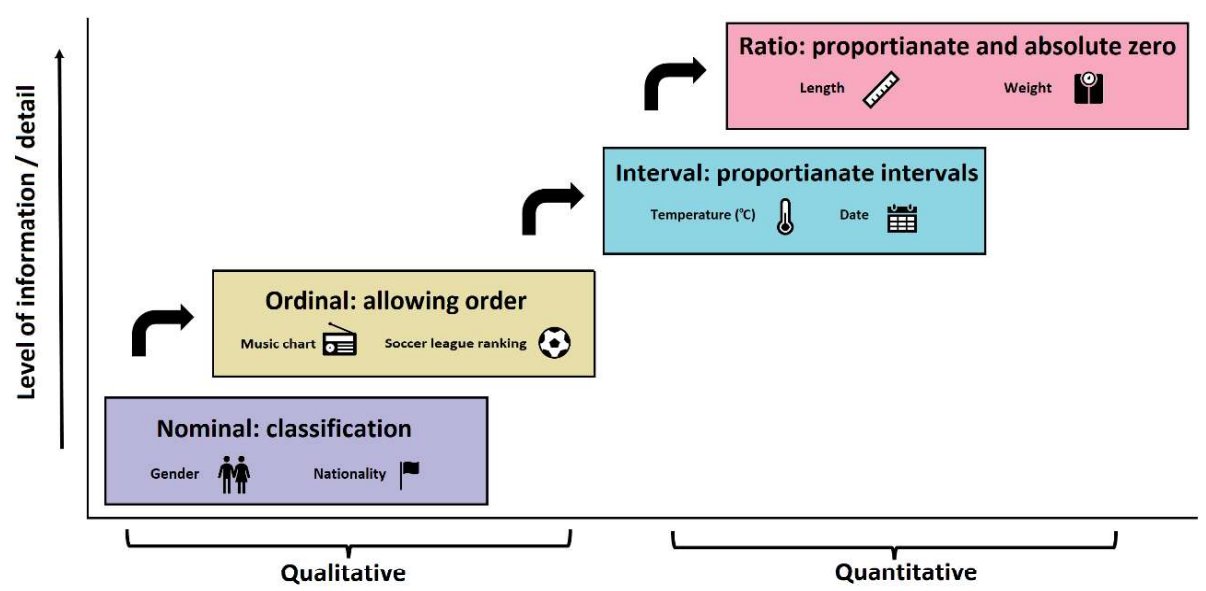

FIGURE 1. Visualisation and examples of the types of measurement of data. 


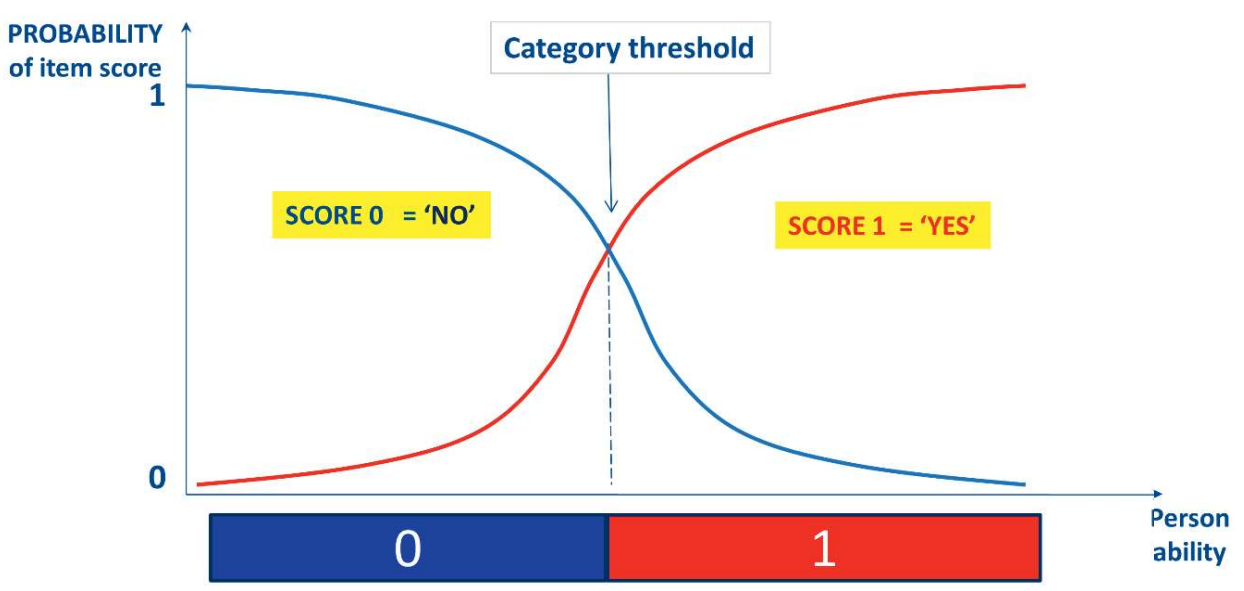

FIGURE 2. Example of part of the IRT/Rasch model.

Legend: the probability of completing an item increases as the Person ability increases, depending on the item difficulty.

and an important concept in this is reliability. Shortcomings of the CTT are that the individual and test itself are inseparable, they can only be interpreted in context of each other. Furthermore, it implies the same standard error of measurement for each individual, which seems highly unlikely. It is a model which is centred around the test, rather than the individual. Outcome measures based on the CTT are ordinal in nature.

A more modern mathematical model is the Item Response Theory (IRT), which is based on the properties of the item rather than the test itself like in the CTT. (16) It assumes that the probability of the response to an item is a mathematical function of both person and item parameters. See Figure 2 and 3 below for a visual depiction of this concept. It factors in the difficulty of an item and the ability of an individual to complete an item. It is often seen as more complete and superior compared to the CTT.

The IRT can help transform data to an interval level, overcoming the shortcomings of ordinal data mentioned above.

The Rasch model is a specialised form of IRT and has conceptual differences. (17) In IRT the aim is to let the model reflect the observed data patterns with additional model parameters, where as in the Rasch model the observed data has to be fitted to the model by fulfilling several requirements. Examples of these requirements are unidimensionality, the absence of residual correlations, disordered thresholds and differential item functioning. 


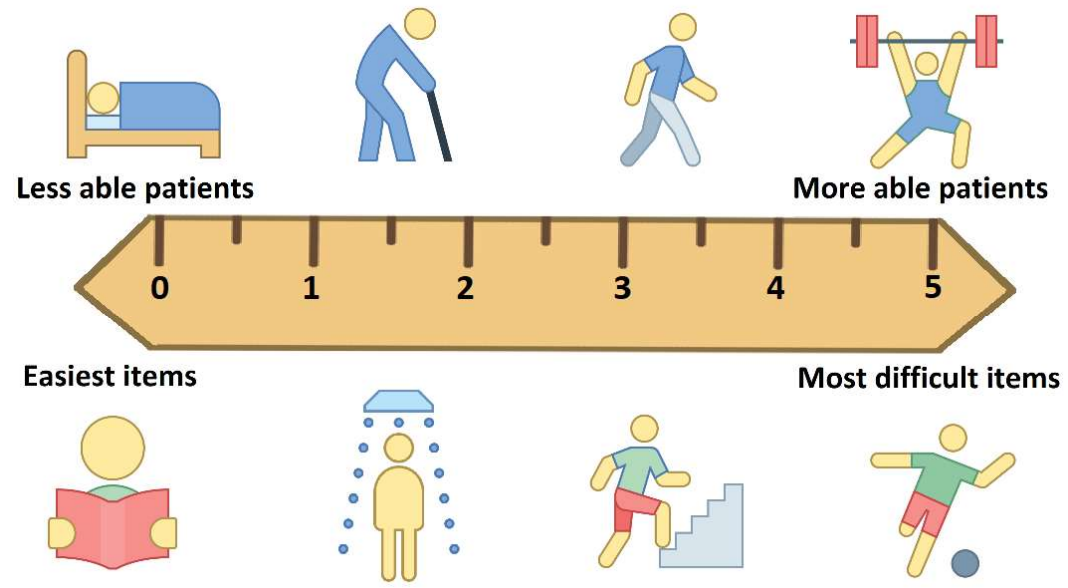

FIGURE 3. Visualisation of the IRT/Rasch model.

The probability of an item response depends on both the ability of a patient as well as the difficulty of an item.

\subsection{THE PERIPHERAL NEUROPATHY OUTCOME MEASURES STANDARDIZATION (PERINOMS) STUDY: AN INTRODUCTION AND RESULTS SO FAR}

The Peripheral Neuropathy outcome Measures Standardization (PeriNomS) study originated from an unmet need for proper outcome measures in inflammatory neuropathies. A consensus was reached between researchers and clinical experts, establishing a core set of outcome measures on different levels of outcome. (18) The selected levels of outcome were pathology, impairment, disability and quality of life. It was also determined that the selected outcome measures had to fulfil basic clinimetric needs of being feasible, valid, reliable and responsive. Based on these recommendations, the PeriNomS study was developed. This international collaborative effort between 26 neuromuscular centres (see Figure 4) consisted of a cross-sectional and a longitudinal part, for which data was collected between 2007 and 2012 .

The cross-sectional part focused on examining validity and reliability in clinical stable patients with residual signs and symptoms. A total of 102 patients with an inflammatory neuropathy (GBS: 30, CIDP: 30, MGUSP: 20 and MMN: 22) were examined at two different occasions at the outpatient clinics in the Netherlands. During these two visits the patients were examined by two independent observers consecutively within 2-4 weeks without having access to the prior results. The patient-reported outcomes were assessed twice by patients in a similar fashion. 


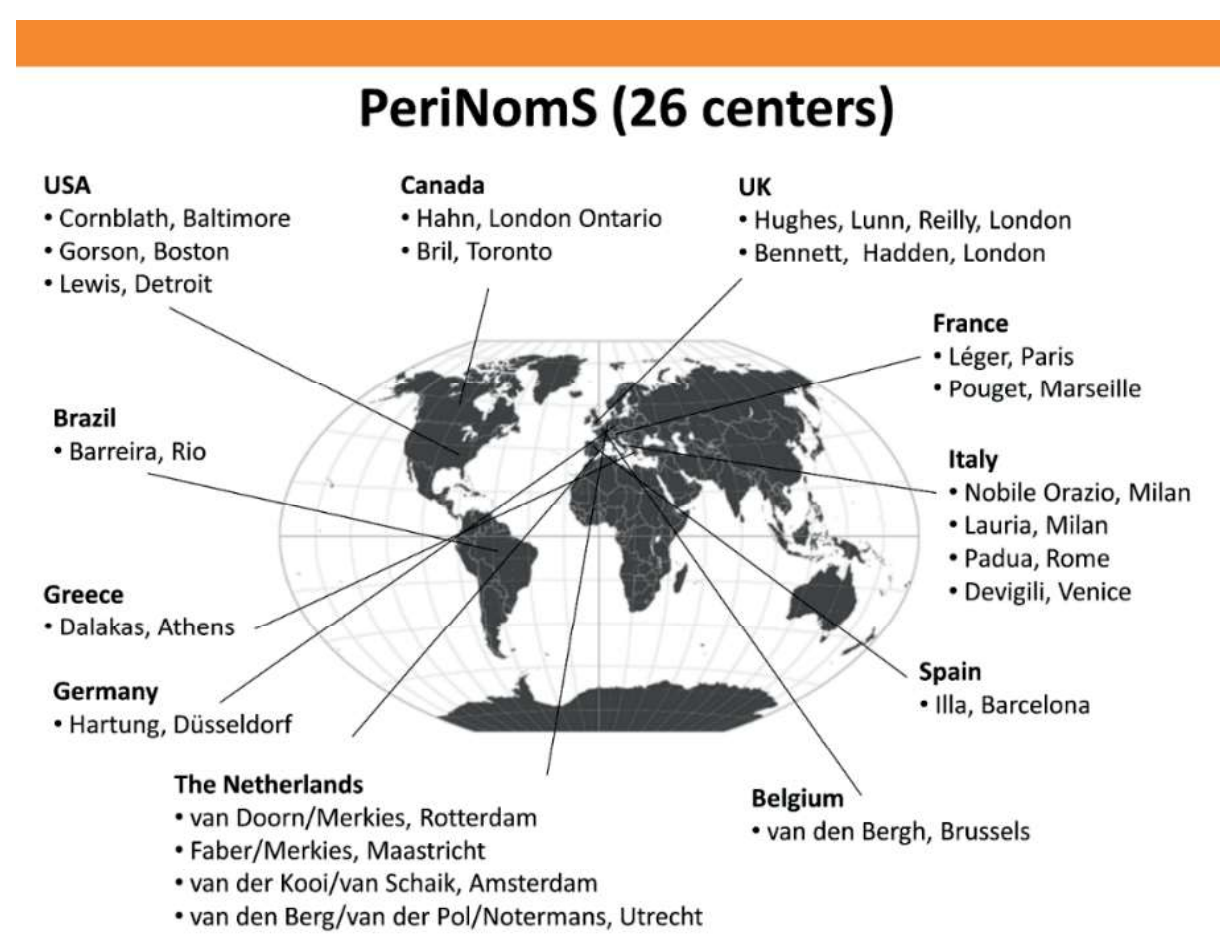

FIGURE 4. Participating centers in the PeriNomS study.

The longitudinal part was performed worldwide and its data was used to perform responsiveness analysis. A total of 163 newly diagnosed patients or patients with a clinical relapse were included. See Table 1 for the distribution between countries and illnesses. Patients with GBS or CIDP were examined at onset and after 1, 3, 6 and 12 months. Patients with MGUSP or MMN were examined at onset and after 3 and 12 months.

\section{PeriNomS study Part 1: Improving and standardising assessment of patients with immune-mediated neuropathies.}

Presented by dr. Sonja I. van Nes who defended her thesis in January 2011. The main focus was on the cross-sectional part of the PeriNomS study.

Her thesis addressed a variation of subjects, including normative value studies, Raschbuilt outcome measures, comparative validity, reliability and responsiveness studies and an introduction into the concept of minimum clinically important difference (MCID). (19) 
TABLE 1. Inclusions per country and illness (longitudinal part).

\begin{tabular}{lccccc}
\hline Country & GBS & CIDP & MGUSP & MMN & Total \\
\hline The Netherlands & 25 & 20 & 8 & 9 & 62 \\
USA & 13 & 16 & 4 & 5 & 38 \\
Italy & 9 & 9 & 3 & 5 & 26 \\
Belgium & 2 & 2 & 5 & 1 & 10 \\
France & 1 & 4 & 1 & 3 & 9 \\
UK & 2 & 2 & 1 & 2 & 7 \\
Canada & 1 & 2 & 1 & 1 & 5 \\
Brazil & 2 & 2 & 0 & 0 & 4 \\
Spain & 0 & 2 & 0 & 0 & 2 \\
\hline Total & 55 & 59 & 23 & 26 & 163 \\
\hline
\end{tabular}

\section{PeriNomS study Part 2: Getting consensus}

Presented by dr. Els K. Vanhoutte who defended her thesis in March 2015. The main focus was developing outcome measures on the impairment and activity/ participation level whilst also analysing their clinimetric properties.

In her thesis a core set of disease-specific outcome measures is presented, which include a modified Medical Research Council (MRC) grading system a newly constructed Rasch-built overall Disability Scale for immune-mediated peripheral neuropathies (I-RODS) and a Rasch-built overall Disability Scale for multifocal motor neuropathy (RODS-MMN). Also the concept of defining a responder was addressed, incorporating Rasch analysis and the MCID. (20)

\subsection{OUTLINE OF CURRENT THESIS}

This thesis will be the third part of the PeriNomS study. It's general aim is to determine whether our outcome measures truly reflect and capture the patient's voice. This is done by analysing and developing new outcome measures through modern clinimetric methods and critically appraising existing outcome measures in inflammatory neuropathies.

In Chapter 2 we demonstrate the responsiveness of the patient-reported I-RODS by applying the MCID-SE method. We also compared it with the clinician-reported Inflammatory Neuropathy Cause and Treatment-Overall Neuropathy Limitation Scale (INCAT-ONLS) after its transformation through Rasch. For both scales we determined a heuristic responsiveness by correlating them with a patient-reported 
outcome measurement, the EuroQol thermometer, in which patients rate their own Quality of Life (QoL) on a scale ranging from 0-100.

In Chapter 3 we critically appraised the outcome measure 'ability to walk', which is commonly used in trials, particularly in GBS and CIDP patients. We tested whether this dichotomous outcome measure truly represents general functionality by comparing it with the I-RODS.

In Chapter 4 we investigated the correlation between a subjective and an objective outcome measure in patients with inflammatory neuropathies. The I-RODS was used as the subjective, patient-reported outcome measure and grip strength, measured by a dynamometer, was used as the objective outcome measure.

In Chapter 5 we present the newly developed Inflammatory Neuropathies Quality of Life (IN-QoL) scale. The IN-QoL is the first disease-specific, interval-based QoL scale in inflammatory neuropathies. Furthermore, we determined its validity, reliability and responsiveness. The latter was done by using the MCID-SE method, both the IN-QoL as well as the EuroQol Visual Analog Scale (EQ-VAS). We also demonstrated the correlation between the IN-QoL and EQ-VAS.

In Chapter 6 we present an overview for neurologists about the concept of the MCID. We discuss the origin of the MCID, summarize methods on how to determine the MCID and pitfalls when applying this concept. In conclusion, we also provide recommendations regarding its use in future clinical trials. 


\section{REFERENCES}

1. Willison HJ, Jacobs BC, van Doorn PA. Guillain-Barre syndrome. Lancet. 2016;388(10045):71727.

2. Hughes RA, Swan AV, van Doorn PA. Intravenous immunoglobulin for Guillain-Barre syndrome. The Cochrane database of systematic reviews. 2014(9):CD002063.

3. Raphael JC, Chevret S, Hughes RA, Annane D. Plasma exchange for Guillain-Barre syndrome. The Cochrane database of systematic reviews. 2012(7):CD001798.

4. Mathey EK, Park SB, Hughes RA, Pollard JD, Armati PJ, Barnett MH, et al. Chronic inflammatory demyelinating polyradiculoneuropathy: from pathology to phenotype. Journal of neurology, neurosurgery, and psychiatry. 2015;86(9):973-85.

5. Oaklander AL, Lunn MP, Hughes RA, van Schaik IN, Frost C, Chalk CH. Treatments for chronic inflammatory demyelinating polyradiculoneuropathy (CIDP): an overview of systematic reviews. The Cochrane database of systematic reviews. 2017;1:CD010369.

6. Gorson KC. An update on the management of chronic inflammatory demyelinating polyneuropathy. Therapeutic advances in neurological disorders. 2012;5(6):359-73.

7. Ramchandren S, Lewis RA. An update on monoclonal gammopathy and neuropathy. Current neurology and neuroscience reports. 2012;12(1):102-10.

8. Joint Task Force of the E, the PNS. European Federation of Neurological Societies/Peripheral Nerve Society Guideline on management of paraproteinemic demyelinating neuropathies. Report of a Joint Task Force of the European Federation of Neurological Societies and the Peripheral Nerve Society--first revision. Journal of the peripheral nervous system : JPNS. 2010;15(3):185-95.

9. Leger JM, Guimaraes-Costa R, Iancu Ferfoglia R. The pathogenesis of multifocal motor neuropathy and an update on current management options. Therapeutic advances in neurological disorders. 2015;8(3):109-22.

10. Umapathi T, Hughes RA, Nobile-Orazio E, Leger JM. Immunosuppressant and immunomodulatory treatments for multifocal motor neuropathy. The Cochrane database of systematic reviews. 2005(3):CD003217.

11. Umapathi T, Hughes RA, Nobile-Orazio E, Leger JM. Immunosuppressant and immunomodulatory treatments for multifocal motor neuropathy. The Cochrane database of systematic reviews. 2015(3):CD003217.

12. Van den Bergh PY, Hadden RD, Bouche P, Cornblath DR, Hahn A, Illa I, et al. European Federation of Neurological Societies/Peripheral Nerve Society guideline on management of chronic inflammatory demyelinating polyradiculoneuropathy: report of a joint task force of the European Federation of Neurological Societies and the Peripheral Nerve Society - first revision. European journal of neurology. 2010;17(3):356-63.

13. Stevens SS. On the Theory of Scales of Measurement. Science. 1946;103(2684):677-80. 
14. DeVellis RF. Classical test theory. Medical care. 2006;44(11 Suppl 3):S50-9.

15. Novick MR. The axioms and principal results of classical test theory. Journal of Mathematical Psychology. 1966;3(1):1-18.

16. Lord FM, Novick MR. Statistical theories of mental test scores. Reading, Mass.,: Addison-Wesley Pub. Co.; 1968. xvii, 568 p. p.

17. Rasch G. Probabilistic models for some intelligence and attainment tests. Copenhagen1960. xiii, 184 p. p.

18. Merkies IS, Lauria G. 131st ENMC international workshop: selection of outcome measures for peripheral neuropathy clinical trials 10-12 December 2004, Naarden, The Netherlands. Neuromuscular disorders : NMD. 2006;16(2):149-56.

19. Van Nes SI. Improving and standardising assessment of patients with immune-mediated neuropathies: Peripheral Neuropathy outcome measures Standardisation study (PeriNomS study - part 1) 2012.

20. E.K. V. Peripheral Neuropathy outcome measures Standardisation (PeriNomS) study part 2: Getting consensus 2015. 

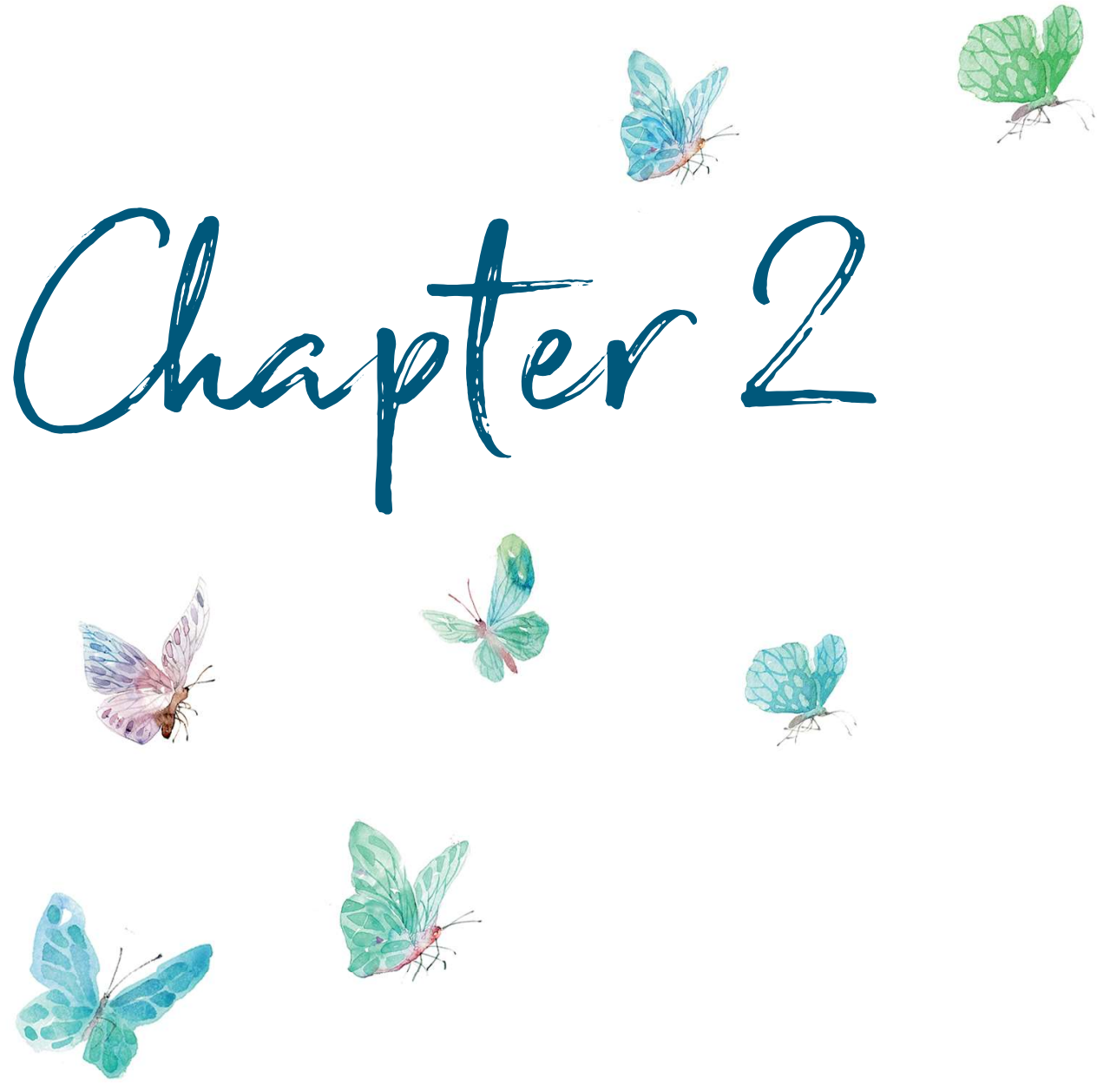


\title{
Changing outcome in inflammatory neuropathies: Rasch comparative responsiveness
}

\author{
Thomas H.P Draak, MD; Els K. Vanhoutte, MD; Sonja I. van Nes, MD, PhD; \\ Kenneth C. Gorson, MD; W. Ludo Van der Pol, MD, PhD; \\ Nicolette. C. Notermans, MD, PhD; Eduardo Nobile-Orazio, MD, PhD; \\ Jean-Marc Léger, MD, PhD; Peter Y.K. Van den Bergh, MD, PhD; \\ Giuseppe Lauria, MD, PhD; Vera Bril, MD, PhD; Hans Katzberg, MD; \\ Michael P.T. Lunn, MD, PhD; Jean Pouget, MD, PhD Anneke J. van der Kooi, MD, PhD; \\ Angelika F. Hahn, MD, PhD; Pieter.A. van Doorn, MD, PhD; David R. Cornblath, MD; \\ Leonard H. van den Berg, MD, PhD; Catharina G.Faber, MD, PhD; \\ Ingemar S.J. Merkies, MD, PhD; \\ on behalf of the PeriNomS study group
}

Adapted from: Neurology. 2014; 83:1-9 


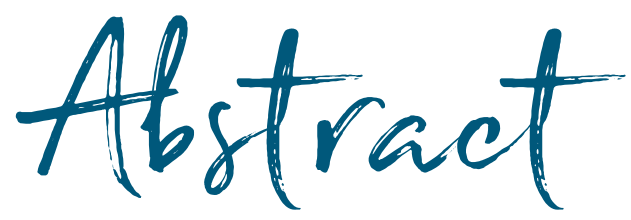

\section{OBJECTIVES}

We performed responsiveness comparison between the patient-reported inflammatory-Rasch-built Overall Disability Scale (I-RODS) and the widely used clinician-reported Inflammatory Neuropathy Cause and Treatment-Overall Neuropathy Limitation Scale (INCAT-ONLS) in patients with Guillain-Barré syndrome (GBS), chronic inflammatory demyelinating polyradiculoneuropathy (CIDP), and immunoglobulin M-monoclonal gammopathy of undetermined significance related polyneuropathy (IgM-MGUSP).

\section{METHODS}

One hundred thirty-seven patients (GBS: 55, CIDP: 59, IgM-MGUSP: 23) with a new diagnosis or clinical relapse assessed both scales. Patients with GBS/CIDP were examined at $0,1,3,6$, and 12 months; patients with IgM-MGUSP at 0,3 , and 12. We subjected all data to Rasch analyses, and calculated for each patient the magnitude of change on both scales using the minimum clinically important difference (MCID) related to the individual standard errors (SE). A responder was defined as having a MCID-SE $\geq 1.96$. Individual scores on both measures were correlated with the EuroQoL thermometer (heuristic responsiveness).

\section{RESULTS}

The I-RODS showed a significantly higher proportion of meaningful improvement compared with the INCAT-ONLS findings in GBS/CIDP. For IgM-MGUSP, the lack of responsiveness during the 1-year study did not allow for a clear separation. Heuristic responsiveness was consistently higher with the I-RODS.

\section{CONCLUSION}

The I-RODS more often captures clinically meaningful changes over time, with a greater magnitude of change, compared to the INCAT-ONLS in patients with GBS and CIDP. The I-RODS offers promise for being a more sensitive measure and its use is therefore suggested in future trials involving patients with GBS and CIDP. 


\section{INTRODUCTION}

Most randomized controlled trials in patients with Guillain-Barré syndrome (GBS), chronic inflammatory demyelinating polyradiculoneuropathy (CIDP), and monoclonal gammopathy of undetermined significance related polyneuropathy (MGUSP) have used primary outcome measures that are ordinal-based, despite their known limitations.(1-8) One of the most widely used scales in these diseases is the 10-point INCAT disability scale,(9) and its latest modified 12-point overall neuropathy limitation scale (INCAT-ONLS).(10) Both scales are clinician reported outcome measures at ordinal level. To overcome the shortcomings of ordinalbased outcome measures, we previously developed a 24-item Rasch-built overall disability interval scale (RODS). This patient reported outcome measure captures activity limitations and participation restrictions at the moment of completion and was specifically designed for patients with GBS, CIDP, and MGUSP.(11) In this report, we refer to the RODS for GBS, CIDP and MGUSP as the InflammatoryRODS (I-RODS). Despite having high internal/external validity, proper reliability scores, and high discriminatory validity, the responsiveness of the I-RODS has not been examined.(11) We investigated the ability of the I-RODS to capture clinically meaningful changes over time in serially examined newly diagnosed or relapsing patients with GBS, CIDP, and IgM-MGUSP. In addition, we compared the responsiveness between the I-RODS and the INCAT-ONLS to determine which scale is superior. Finally, we performed cross-cultural evaluation for the most responsive scale.

\section{METHODS}

\section{Patients}

This study is part of the Peripheral Neuropathy outcome measures Standardization (PeriNomS) study (duration: 7 years; database closed 31 $1^{\text {st }}$ December 2012), an international collaborative effort of 26 neuromuscular centres with a special interest in inflammatory neuropathies, located in nine countries (United States, Canada, Spain, Brazil, Italy, France, Belgium, the Netherlands, and United Kingdom). The primary aim of the PeriNomS study is to select the most responsive outcome measures in GBS, CIDP, and IgM-MGUSP and to develop a core set of outcome measures for each illness to be used in future clinical studies.

The participating centres recruited and serially examined a total of 137 patients with newly diagnosed (or clinically relapsing) GBS, CIDP, and IgM-MGUSP during a 12-month follow-up period. Patients were treated at the discretion of their physician. 


\section{Eligibility, Standard Protocol Approvals, Registrations, and Patient Consents}

Eligibility included normal cognitive function, age $\geq 18$ years, fulfilling international criteria for the diagnosis GBS, CIDP, or IgM (preferably anti-MAG+)MGUSP,(12-14) having clinical deterioration as judged by the patient and physician, and not receiving immune-therapy for their polyneuropathy at least 2 months prior to inclusion. Patients were excluded if other causes of polyneuropathy (e.g. renal insufficiency, diabetes mellitus, etc.) or any other conditions (e.g. alcohol abuse: $>5$ IU/day) that might interfere with nervous system and physical functioning (e.g. arthritis) were present.

All patients gave written informed consent before participation in the study. The local Medical Ethics Committee in each participating center approved the protocol.

\section{Rasch method and Outcome assessments}

The Rasch model is a modern technique that enables the transformation of ordinalbased outcome measures to the interval level. $(11,15,16)$ Rasch states that the probability that a person may affirm an item/task depends on the item difficulty and the person's level of ability (level of being ill). Readers are invited to a more comprehensive and educational explanation of the Rasch methodology using the supplementary material of the original I-RODS paper.(11, 16) The I-RODS comprises 24 items that address daily and social activities (easiest item: ability to read a book/newspaper; most difficult item: ability to run) and has 3 response options: (0) "impossible to perform", (1) "performed with difficulty", and (2) "easily performed". (11) The I-RODS is easy to complete (in 2-3 minutes) by the patient or caregiver and the scores are at the interval level after Rasch-method transformation, therefore having a higher degree of data recruitment precision when compared to ordinalbased measures.(17) Its scores are expressed in log-odds (logits).(11, 16)

The INCAT-ONLS, assessed by the physician, has never been clinimetrically evaluated, but two very similar scales have demonstrated their scientific soundness that can be extrapolated to the INCAT scale. $(10,18)$ The INCAT-ONLS provides good functional descriptions in a checklist format, suitable for interviewing patients. Daily activities such as dressing the upper part of the body, (un)doing buttons/ zippers, washing/brushing hair, using a knife and fork, turning a key in a lock, and problems with walking are assessed, and the results are summated into an Arm grade (0-5) and a Leg grade (0-7) (total INCAT-ONLS score ranges from 0 ("no signs of disability") to 12 ("most severe disability score")).(9, 10) 


\section{Procedures and Statistics General aspects}

The I-RODS and the INCAT-ONLS were assessed at $0 / 1 / 3 / 6 / 12$ months in patients with GBS/CIDP; because of the more indolent disease course, patients with IgMMGUSP were examined at 0/3/12 months.(14)

We have provided patients and physicians with standardized instructions how to complete the outcome measures. The data from both scales, including the following person factors, were subjected to Rasch analyses: sex, age ( $<50$ versus 50 to 65 versus 65 years and older; cut-offs chosen aiming for approximately equal distribution), and illness (GBS versus CIDP versus IgM-MGUSP). It was not possible to assess each country as an individual person factor as the number of patients recruited per country was generally low, except for the Netherlands (61\% were Dutch). Therefore, the following cultural factors were formulated and entered: living in the Netherlands (Yes/No), Europe (Yes/No), with further geographic divisions that included northern Europe (United Kingdom, Belgium, the Netherlands) versus southern Europe (Italy, France, Spain), versus North and South America (United States, Canada, Brazil).

\section{Responsiveness comparison strategies}

We have chosen two strategies to compare responsiveness for both scales in the serially examined patients:

Strategy 1: We performed a comparison of responsiveness at the individual person level using individual standard errors (SE) after subjecting the data to the Rasch method. As previously stated, Rasch is capable of constructing interval measures from counts of qualitatively-ordered observations. $(15,16,19)$ SEs may vary across the theoretical range of an outcome measure, and therefore the significance of a clinically meaningful change in any particular patient may also vary. $(15,20-22)$ The Minimally Clinically Important Difference (MCID) related SE (MCID-SE) score is based on the previously described significant changes. $(15,20)$ Briefly, MCID-SE was computed for each Rasch-transformed scale (I-RODS versus INCAT-ONLS) in each of the 137 examined patients separately: 1) their personal change (personallocation at $i$ month minus personal-location at baseline (entry); where $i=1,3$, 6 or 12 months of follow-up in GBS and CIDP, and 3 and 12 months in IgMMGUSP), 2) the corresponding SE of difference related to their individual change $\left(\mathrm{SE}_{\text {diff }}=\right.$ square-root $\left.\left(\mathrm{SE}_{\text {entry }}{ }^{2}+\mathrm{SE}_{i \text { month }}{ }^{2}\right)\right)$, and 3) the final MCID-SE calculations were computed by dividing the individual change scores by their corresponding $\mathrm{SE}_{\text {diff }}$ (MCID-SE $=$ (personal-location at $i$ month minus personal-location at entry)/SE $\mathrm{diff}_{\text {iff }}$ ). (20) Subsequently, the calculated MCID-SE findings were divided into the following subgroups: subgroup 1 (clinically important improvement): MCID-SE $\geq 1.96$; subgroup 2 (clinically unimportant improvement): $0<\mathrm{MCID}-\mathrm{SE}<1.96$; subgroup 
3 (no change): $\mathrm{MCID}-\mathrm{SE}=0$; subgroup 4 (clinically unimportant deterioration): $-1.96<$ MCID-SE $<0$; and subgroup 5 (clinically important deterioration): MCID$\mathrm{SE} \leq-1.96) .(20)$

Strategy 2: We took a more patient-oriented approach to determine the so-called "heuristic responsiveness" for both scales. $(23,24)$ Heuristic techniques are based upon comparing changes using a scale with an external indicator as completed by patients. $(23,24)$ In the current study, we have chosen the personal patient-derived EuroQoL "thermometer", because this ruler helps patients to indicate their personal health status (range: 0 (worst state) to 100 (best state)).(25) These scores were correlated with the scores (patient's ability, (logits)) of each individual patient after subjecting the data for both scales to Rasch.

Statistics for Strategy 1: The proportion of patients reaching clinically important improvement on both scales was compared in GBS, CIDP, and IgM-MGUSP separately. An accepted cut-off value for the definition of a clinically important improvement is $\geq 1.96 x$ personal obtained $\mathrm{SE}$, at a chosen specificity of $95 \%$ confidence interval. $(15,20,22)$ Subsequently, as previously described, we created Kaplan-Meier curves to estimate and compare the cumulative proportion of patients per illness (overall, and separately in GBS, CIDP, and IgM-MGUSP) demonstrating significant improvement over time (at 1, 3, 6, and 12 months of follow-up) for both scales (I-RODS versus INCAT-ONLS).(26) The log-rank test was used to examine possible group differences.

Statistics for Strategy 2: Univariate regression studies using splines (to improve data fitting) were performed to determine a possible correlation between the Rasch-transformed personal scores and the EuroQoL-thermometer for both scales (correlation presented as $\mathrm{R}^{2}$ : the fraction of variance explained by the independent variables).(27)

\section{Cross-cultural evaluation of the most responsive scale}

Immune-mediated neuropathies are rare disorders and therefore most randomized trials in these patients have been completed through multicenter international studies. A prerequisite is that outcome measures used internationally in any condition must overcome general cross-cultural differences. $(28,29)$ Thus far, no outcome measure in inflammatory neuropathy studies has been cross-culturally validated. In the current study, the person factors 'the Netherlands', 'Europe', and 'culture-difference' were used to determine the cultural validity of the most responsiveness scale (I-RODS or INCAT-ONLS).(28) In essence, the data from the various regions are compared through differential item functioning (DIF) analyses using the $95^{\text {th }}$-confidence interval boundaries to determine invariance as has been addressed previously as an 
acceptable surrogate marker to examine cultural differences.(28) Invariance suggests that the probability of a patient in one region completing an item will be the same as the probability of a patient in another region affirming the same item, given that they are both at the same trait level (having the same degree of functional deficit). $(28,30)$

\section{Software}

We performed Rasch analyses using RUMM2030 with a partial credit model as default.(31) The I-RODS data were easily subjected to RUMM2030, since all 24 items are straightforward with equal (3) response options.

For the INCAT-ONLS, we used two approaches:

1. The arm grade and leg grade scores were subjected to RUMM2030 as if the INCAT-ONLS scale was composed by these 2 independent items; this approach was chosen as the arm and leg grades have been used to detect meaningful changes after an intervention;

2. The INCAT-ONLS was also redefined to its original five arm activities plus two items addressing mobility (1: do you have walking difficulty: No/Yes and 2: how do you usually mobilize outdoors: independently/with one stick/with two sticks/ with a wheelchair). These seven items were subjected to RUMM2030 as a group of individual items.

Hence, the I-RODS Rasch data were compared with both Rasch-transformed (RT2-item and RT-7-item) INCAT-ONLS approaches. Further analyses were performed using Stata for Windows XP (version 12.0, StataCorp, College Station, Texas, United States). Differences in possible ceiling and floor percentages between scales were also examined ( $\mathrm{X}^{2}$-test; $\mathrm{p}$-value $<0.05$ was accepted as statistically significant).

\section{RESULTS}

\section{Patients}

The demographics of the 137 patients are presented in Table 1. Nineteen of the 23 patients with IgM-MGUSP had anti-MAG antibodies. There were a total of 600 patient visits, and $94 \%$ of the patients completed 1-year follow-up.

\section{Comparison I-RODS versus INCAT-ONLS General aspects}

The I-RODS had overall lower SEs than seen with the INCAT-ONLS (Figure 1) and also demonstrated significantly lower ceiling scores (I-RODS ceiling: 9.5\% of 
TABLE 1. General characteristics of longitudinal recruited patients $(n=137)$.

\begin{tabular}{|c|c|c|c|}
\hline Diagnosis & GBS & CIDP & IgM-MGUSP \\
\hline Number of patients & 55 & 59 & 23 \\
\hline \multicolumn{4}{|l|}{ Age (years) } \\
\hline mean (SD) & $53.4(17.7)$ & $52.7(14.7)$ & $62.8(10.6)$ \\
\hline range & $19-90$ & 18-79 & 45-85 \\
\hline \multicolumn{4}{|l|}{ Gender, number (\%) } \\
\hline Female & $18(32.7)$ & $17(28.8)$ & $8(34.8)$ \\
\hline Male & $37(67.3)$ & $42(71.2)$ & $15(65.2)$ \\
\hline \multicolumn{4}{|l|}{ Country of assessment } \\
\hline the Netherlands & 25 & 20 & 8 \\
\hline USA & 6 & 11 & 4 \\
\hline Italy & 9 & 9 & 3 \\
\hline Spain & - & 2 & - \\
\hline France & 1 & 4 & 1 \\
\hline Belgium & 2 & 2 & 5 \\
\hline United Kingdom & 2 & 2 & 1 \\
\hline Canada & 8 & 7 & 1 \\
\hline Brazil & 2 & 2 & - \\
\hline \multicolumn{4}{|l|}{ Current medication (\%)* } \\
\hline IVlg and/or Steroids & 81.8 & 67.8 & 34.8 \\
\hline Plasma Exchange & 16.4 & 5.1 & 17.4 \\
\hline Immunosuppressive & - & 3.4 & 13 \\
\hline Other & - & 10.2 & 34.8 \\
\hline
\end{tabular}

GBS: Guillain-Barré syndrome; CIDP: chronic inflammatory demyelinating polyradiculoneuropathy; IgMMGUSP: IgM monoclonal gammopathy of undetermined significant related polyneuropathy; IVIg: intravenous immunoglobulin. *Note: some missing data on medication use.

all records, Rasch transformed-2-item INCAT-ONLS: 17.4\%, RT-7-item INCATONLS: $20.8 \%$; $\mathrm{X}^{2}$-tests: $\mathrm{p}<0.001$ ). Both measures demonstrated minimum floor effects, but these were not significantly different (I-RODS: 2.9\%; 2-item INCATONLS: $1.7 \%$; 7-item INCAT-ONLS: $2.9 \%$ ).

\section{Comparison at the individual personal level using MCID-SE cut-off}

A significantly higher cumulative proportion of patients with GBS/CIDP demonstrated a meaningful improvement (MCID-SE cut-off $\geq 1.96$ ) when assessed with the I-RODS versus the INCAT-ONLS (Figure 2; $p$-values: $\mathrm{p}=0.01$ to $\mathrm{p}<0.001$, favoring the I-RODS). In IgM-MGUSP, only a small proportion of these patients reached this cut-off $(<20 \%)$ in both scales (Figure 2; $\mathrm{p}=0.02$ favoring the I-RODS versus RT-2-item INCAT-ONLS). The responsiveness was consistently higher in GBS compared to the other illnesses. 


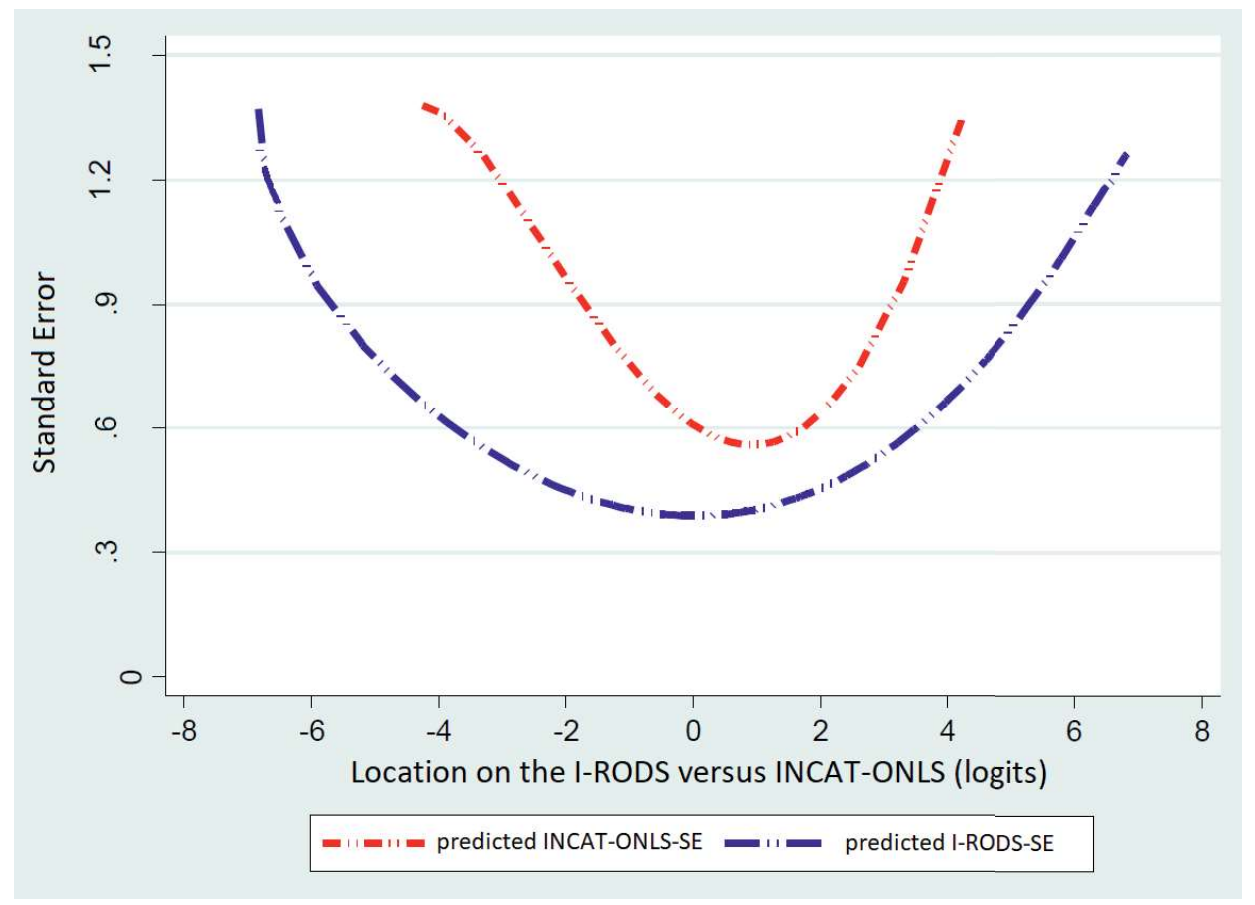

FIGURE 1: Location on the I-RODS versus INCAT-ONLS related to the corresponding individual standard errors.

The range of the I-RODS was larger in the same population at examination compared to the findings in the INCAT-ONLS scales. Data shown here are for the RT-7-item INCAT-ONLS scale. The corresponding SEs were practically the same for the RT-2-item (arm and leg grade) INCAT-ONLS as for the RT-7-item INCATONLS. I-RODS: inflammatory Rasch-built Overall Disability Scale; INCAT: Inflammatory Neuropathy Cause And Treatment Scale; ONLS: overall neuropathy limitation scale; RT: Rasch transformed; SE: standard error.

At 1-year follow-up, 97\% of patients with GBS reached the MCID-SE cut-off scores using the I-RODS versus $80 \%$ for the RT-2-item INCAT-ONLS and $82 \%$ for the RT-7-item INCAT-ONLS; in CIDP these numbers were 42\% (I-RODS) versus 20\% (RT-2-item INCAT-ONLS) and 30\% (RT-7-item INCAT-ONLS) (Figure 3).

\section{Comparison through heuristic responsiveness}

The correlation found between the EuroQol-thermometer and patient's ability is presented in Table 2. The association between the I-RODS and EuroQolthermometer was consistently higher when compared with the INCAT-ONLSEuroQoL-thermometer associations. The obtained values were higher in patients with GBS > CIDP > IgM-MGUSP. 


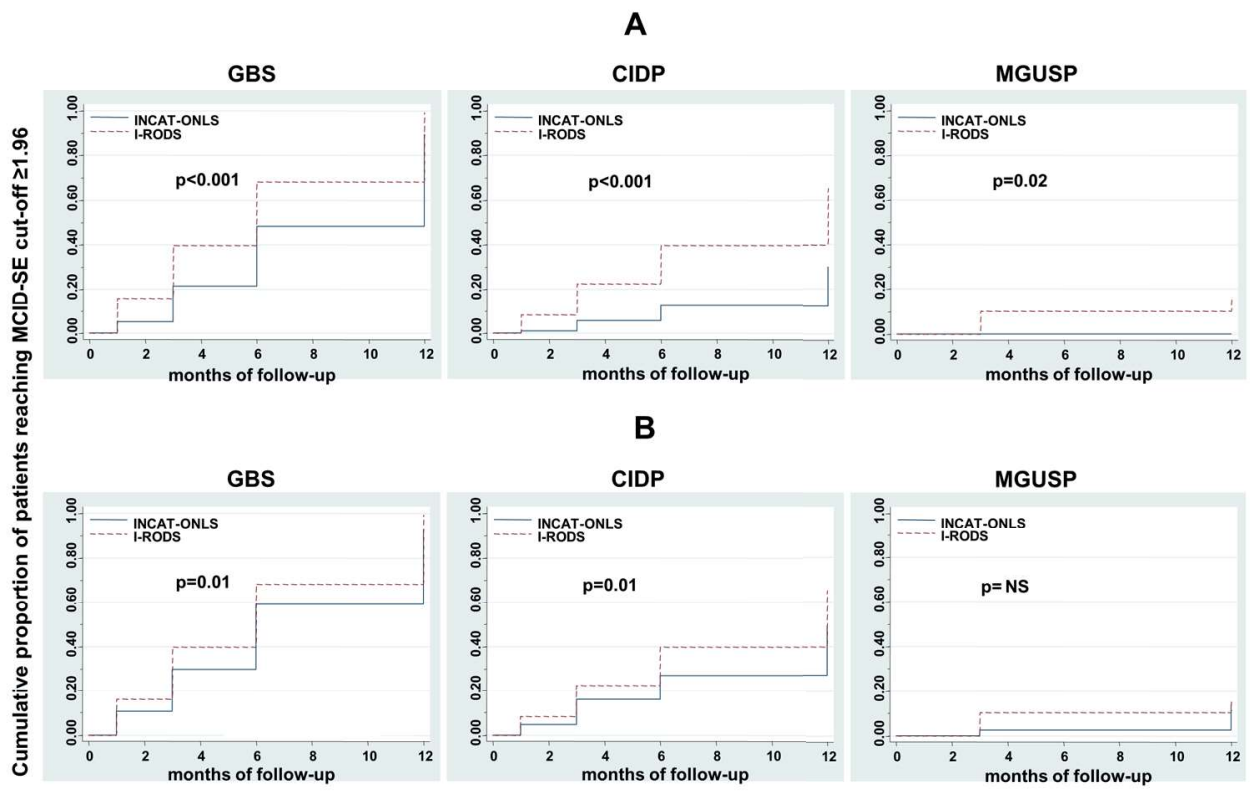

FIGURE 2. Comparing improvement between the I-RODS vs (A) the RT-2-item INCAT-ONLS and (B) the RT7-item INCAT-ONLS.

A consistently higher proportion of patients reached a significant meaningful improvement (MCID-SE cutoff 2 1.96) when assessed with the I-RODS vs the INCAT-ONLS. In patients with IgM-MGUSP, the number of patients with a significant change was very low.

GBS = Guillain-Barré syndrome; CIDP = chronic inflammatory demyelinating polyradiculoneuropathy MGUSP $=$ monoclonal gammopathy of undetermined significance related polyneuropathy; INCAT = Inflammatory Neuropathy Cause and Treatment; ONLS = Overall Neuropathy Limitation Scale; I-RODS = Inflammatory Rasch-built Overall Disability Scale; MCID-SE = minimal clinically important differencestandard error; NS = not significant; RT = Rasch-transformed;

\section{Cross-cultural validation}

Subsequently, we examined the cross-cultural validity of the I-RODS as the most responsiveness scale (Figure 4). Most items were within the 95\%-confidence interval boundaries indicating proper hierarchical ordering and had no DIF. However, 5 of these items showed DIF on several cross-cultural factors: one item ("able to travel by public transport") showed uniform-DIF on person factor "the Netherlands"; two items ("able to walk outdoors" and "able to move a chair") had uniform-DIF on "Europe"; and two items ("able to wash lower body" and "able to walk and avoid obstacles") had uniform-DIF on "cultural-difference". 

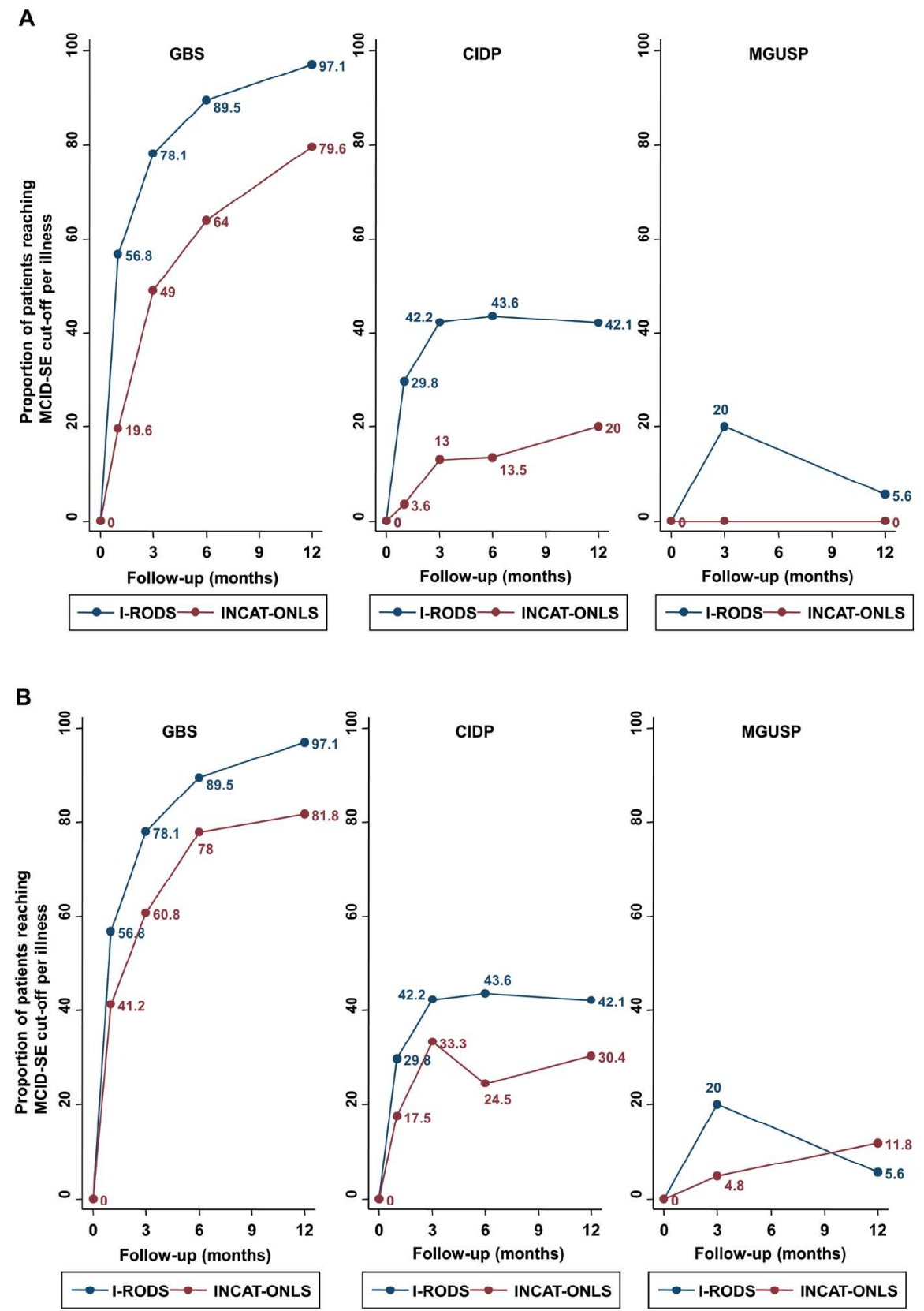

FIGURE 3. Comparison in improvement between the I-RODS vs the (A) RT-2-item INCAT-ONLS and (B) RT-7item INCAT-ONLS.

GBS = Guillain-Barré syndrome; CIDP = chronic inflammatory demyelinating polyradiculoneuropathy; MGUSP = monoclonal gammopathy of undetermined significance related polyneuropathy; INCAT = Inflammatory Neuropathy Cause and Treatment; ONLS = Overall Neuropathy Limitation Scale; I-RODS = Inflammatory Rasch-built Overall Disability Scale; MCID-SE = minimal clinically important differencestandard error; RT = Rasch-transformed; 
TABLE 2. Correlations between EQ-thermometer and I-RODS and INCAT-ONLS.

\begin{tabular}{lcc}
\hline & EQ-thermometer $\left(\mathbf{R}^{2}\right)$ & Corresponding $\mathrm{p}$-value \\
\hline Overall & 0.52 & $\mathrm{p}<0.0001$ \\
I-RODS & 0.45 & $\mathrm{p}<0.0001$ \\
2-item RT-INCAT-ONLS & 0.44 & $\mathrm{p}<0.0001$ \\
7-item RT-INCAT-ONLS & & \\
GBS & 0.61 & $\mathrm{p}<0.0001$ \\
I-RODS & 0.54 & $\mathrm{p}<0.0001$ \\
2-item RT-INCAT-ONLS & 0.56 & $\mathrm{p}<0.0001$ \\
7-item RT-INCAT-ONLS & & $\mathrm{p}<0.0001$ \\
CIDP & 0.42 & $\mathrm{p}<0.0001$ \\
I-RODS & 0.32 & $\mathrm{p}<0.0001$ \\
2-item RT-INCAT-ONLS & 0.30 & \\
7-item RT-INCAT-ONLS & & $\mathrm{p}<0.0001$ \\
MGUSP & 0.30 & $\mathrm{p}=0.0001$ \\
I-RODS & 0.27 & $\mathrm{p}=0.0001$ \\
2-item RT-INCAT-ONLS & 0.21 & \\
7-item RT-INCAT-ONLS & & \\
\hline
\end{tabular}

The strength of association is presented as $R^{2}$ : the fraction of variance explained by the independent variables from a regression model. GBS = Guillain-Barré syndrome; $C I D P=$ chronic inflammatory demyelinating polyradiculoneuropathy; MGUSP = monoclonal gammopathy of undetermined significance related polyneuropathy; INCAT = Inflammatory Neuropathy Cause and Treatment; ONLS = Overall Neuropathy Limitation Scale; I-RODS = Inflammatory Rasch-built Overall Disability Scale.

\section{DISCUSSION}

We found that the I-RODS was a more responsive scale in GBS and CIDP compared to the widely used ordinal-based INCAT-ONLS using the MCID concept related to the varying standard errors seen throughout the Rasch-transformed scales' continuum. Based on the results in the current study, experts in the field recently suggested the I-RODS as the primary outcome measure for future trials involving patients with GBS and CIDP.(21)

In this study $<20 \%$ of IgM-MGUSP patients demonstrated clinical changes. The number of IgM-MGUSP patients in this study was small, the medical interventions varied, and few patients had any clinically meaningful response to any treatment. These factors have made it exceptionally difficult to assess responsiveness in this indolent disease. More importantly, our data suggest that 1-year follow-up may be insufficient to assess clinically meaningful changes in this disorder. This observation is especially relevant because prior treatment trials in IgM-MGUSP have had a short duration (< 1 year). $(4,32)$ 

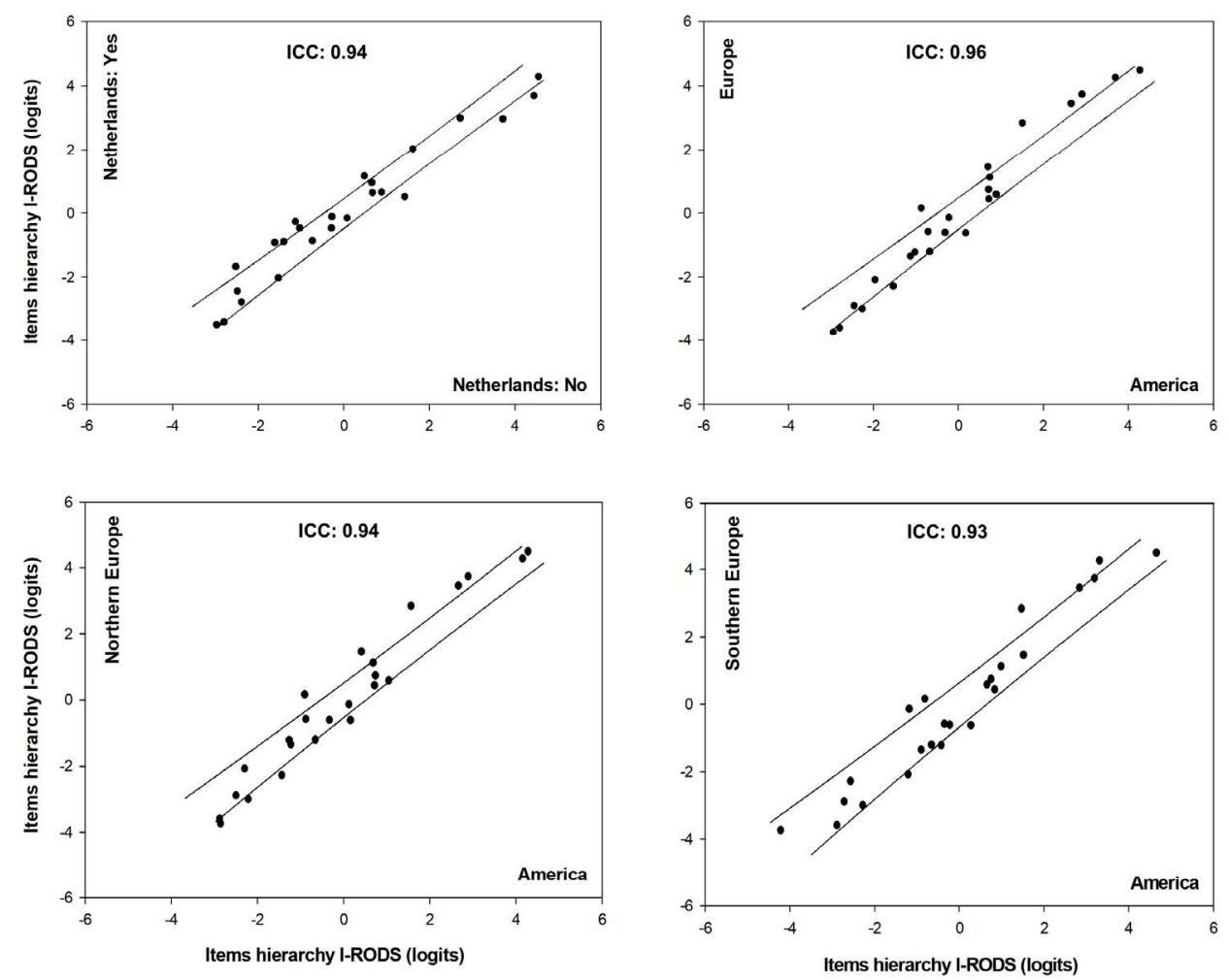

FIGURE 4. The invariance of the items' hierarchy of the I-RODS across countries and regions.

Most items of the I-RODS fell within the $95 \%$-confidence interval (solid) lines indicating that most items are ranked with the same hierarchy between the groups being compared and show no DIF; easiest items are at the bottom left part and most difficult items at the right top part. However, some items fall outside the $95 \%-\mathrm{Cl}$. A total of 5 of the 24 items showed DIF. DIF: differential item functioning; ICC: intraclass correlation coefficient; I-RODS: inflammatory Rasch-built overall disability scale.

The INCAT-ONLS was transformed through Rasch into a 2-item and 7-item scale, creating a higher level of measurement precision for the INCAT-ONLS data and thereby bypassing the shortcomings of ordinal-based scales. $(7,8)$ The INCAT-ONLS remained less responsive compared to the I-RODS. The findings in the current study may also be seen as a new way to define "being a responder" for future trial design in inflammatory neuropathies and may serve as a frame for other neurological illnesses, facing the same ordinal-based deficiencies, $(20,33)$ as well as for other disciplines (e.g., rheumatology) treating patients with chronic conditions.

The results of this and other studies $(17,34,35)$ pose a considerable and much broader question: why do neurologists continue to use ordinal measures in clinical trials despite the known constraints? Several facets may explain the improper use of ordinal measures: First, most neurologists consider observations in clinical setting 
as real measurements and are unaware that quantitative observations are based on counting observed events, while meaningful measurements are based on the arithmetical properties of interval scales. $(7,17,36)$. Observations, like daily activities as part of the INCAT-ONLS with their Likert-type response options are thus ordinal and provide a good description of the clinical question of interest. The problem arises when we start giving the ordinal descriptions numbers arbitrarily, create sum scores, treating these scores as linear, and make assumptions from the findings. $(7,37,38)$ Second, the current medical curriculum does not provide training in clinimetrics, the science that addresses measurement requirements in the clinical setting, and therefore, the exposure of this knowledge to physicians is relatively poor. As a consequence, experts in any medical field or illness generally provide information regarding "the best way" to assess clinical changes in a particular illness of interest, assuming, often incorrectly, that they have the proper knowledge to do so. Subsequently, the risk of drawing incorrect inferences from trials with ordinal measures as the primary outcome becomes high, but this remains generally unacknowledged. $(17,34)$ Positive trials may be falsely positive and vice versa. Comparison of raw I-RODS (with an arbitrarily taken cut-off) versus ordinal INCAT-ONLS (using a 1-point cut-off as often suggested) is therefore considered a less proper solution. We simply do not know what we are measuring and the comparison becomes uncertain. $(17,38,39)$ Third, when being exposed to modern methods like the Rasch and Item Response Theory, physicians generally may become somewhat uncomfortable and opposed to these techniques mostly due to their less accessible arithmetical properties. This may contribute to a "holding-on attitude" of physicians to the seemingly more intuitive, but less proper ordinal-based measures. Reporting results in future trials could shift from comparing two groups by looking at p-values to reporting proportions of patients that demonstrated individual meaningful improvement using the MCIDSE method as proposed here.

There are limitations to our study that should be addressed. First, it would have been ideal to have at least 50 patients per illness and country included in the study to properly evaluate the cross-cultural validation of the I-RODS. As GBS, CIDP, and IgM-MGUSP are rare disorders, recruitment was challenging. Second, although the I-RODS scale is easily applicable, some caution is warranted as 5 of its 24 items demonstrated item bias in different geographical regions and the applicability of these items to different settings needs further cross-cultural exploration. Third, although responsiveness was demonstrated using the MCID-SE technique and the heuristic approach using the EuroQol-VAS, further anchor-based evaluation may be desirable to extent the comparison with existing instruments. These points are part of the future scope of the PeriNomS study group. Fourth, although not part of the current study, efforts are being taken to validate the I-RODS as a ruler to assess functionality by presenting its final content again to focussed groups of patients with GBS and 
CIDP and to examine the various ways the I-RODS could be used in future clinical studies. Patients may be encouraged to indicate which target (level of functionality) they want to reach on the I-RODS ruler, the so-called patient's Functional Acceptable Clinical Threshold (FACT) that may change with the changing clinical condition of patients as has been reported in another discipline.(40) Despite these limitations, the I-RODS is the only outcome measure at the interval level that has demonstrated acceptable cultural validation in inflammatory neuropathies, in addition to having higher responsiveness scores when compared to the INCAT-ONLS. The use of the I-RODS offers promise for being a more sensitive measure in future trials involving patients with GBS and CIDP. Additional studies in IgM-MGUSP are needed, as the responsiveness in this indolent condition was relatively poor. 


\section{REFERENCES}

1. Hughes RA, Donofrio P, Bril V, Dalakas MC, Deng C, Hanna K, et al. Intravenous immune globulin ( $10 \%$ caprylate-chromatography purified) for the treatment of chronic inflammatory demyelinating polyradiculoneuropathy (ICE study): a randomised placebo-controlled trial. Lancet neurology. 2008;7(2):136-44.

2. Dalakas MC, Rakocevic G, Salajegheh M, Dambrosia JM, Hahn AF, Raju R, et al. Placebocontrolled trial of rituximab in IgM anti-myelin-associated glycoprotein antibody demyelinating neuropathy. Annals of neurology. 2009;65(3):286-93.

3. van Koningsveld R, Schmitz PI, Meche FG, Visser LH, Meulstee J, van Doorn PA, et al. Effect of methylprednisolone when added to standard treatment with intravenous immunoglobulin for Guillain-Barre syndrome: randomised trial. Lancet. 2004;363(9404):192-6.

4. Leger JM, Viala K, Nicolas G, Creange A, Vallat JM, Pouget J, et al. Placebo-controlled trial of rituximab in IgM anti-myelin-associated glycoprotein neuropathy. Neurology. 2013;80(24):221725.

5. Nobile-Orazio E, Cocito D, Jann S, Uncini A, Beghi E, Messina P, et al. Intravenous immunoglobulin versus intravenous methylprednisolone for chronic inflammatory demyelinating polyradiculoneuropathy: a randomised controlled trial. Lancet neurology. 2012;11(6):493-502.

6. van Schaik IN, Eftimov F, van Doorn PA, Brusse E, van den Berg LH, van der Pol WL, et al. Pulsed high-dose dexamethasone versus standard prednisolone treatment for chronic inflammatory demyelinating polyradiculoneuropathy (PREDICT study): a double-blind, randomised, controlled trial. Lancet neurology. 2010;9(3):245-53.

7. DeVellis RF. Classical test theory. Med Care. 2006;44(11 Suppl 3):S50-9.

8. Merkies IS, Lauria G, Faber CG. Outcome measures in peripheral neuropathies: requirements through statements. Current opinion in neurology. 2012;25(5):556-63.

9. Hughes R, Bensa S, Willison H, Van den Bergh P, Comi G, Illa I, et al. Randomized controlled trial of intravenous immunoglobulin versus oral prednisolone in chronic inflammatory demyelinating polyradiculoneuropathy. Annals of neurology. 2001;50(2):195-201.

10. Graham RC, Hughes RA. A modified peripheral neuropathy scale: the Overall Neuropathy Limitations Scale. J Neurol Neurosurg Psychiatry. 2006;77(8):973-6.

11. van Nes SI, Vanhoutte EK, van Doorn PA, Hermans M, Bakkers M, Kuitwaard K, et al. Raschbuilt Overall Disability Scale (R-ODS) for immune-mediated peripheral neuropathies. Neurology. 2011;76(4):337-45.

12. Van der Meche FG, Van Doorn PA, Meulstee J, Jennekens FG. Diagnostic and classification criteria for the Guillain-Barre syndrome. Eur Neurol. 2001;45(3):133-9. 
13. European Federation of Neurological Societies/Peripheral Nerve Society Guideline on management of chronic inflammatory demyelinating polyradiculoneuropathy: report of a joint task force of the European Federation of Neurological Societies and the Peripheral Nerve Society--First Revision. J Peripher Nerv Syst. 2010;15(1):1-9.

14. European Federation of Neurological Societies/Peripheral Nerve Society Guideline on management of paraproteinemic demyelinating neuropathies. Report of a Joint Task Force of the European Federation of Neurological Societies and the Peripheral Nerve Society--first revision. J Peripher Nerv Syst. 2010;15(3):185-95.

15. Rasch G. Probabilistic models for some intelligence and attainment tests. Chicago: University of Chicago Press; 1960.

16. Tennant A, Conaghan PG. The Rasch measurement model in rheumatology: what is it and why use it? When should it be applied, and what should one look for in a Rasch paper? Arthritis Rheum. 2007;57(8):1358-62.

17. Wright $\mathrm{BD}$, Linacre JM. Observations are always ordinal; measurements, however, must be interval. Arch Phys Med Rehabil. 1989;70(12):857-60.

18. Merkies IS, Schmitz PI, van der Meche FG, Samijn JP, van Doorn PA. Clinimetric evaluation of a new overall disability scale in immune mediated polyneuropathies. J Neurol Neurosurg Psychiatry. 2002;72(5):596-601.

19. Hermans MC, Faber CG, De Baets MH, de Die-Smulders CE, Merkies IS. Rasch-built myotonic dystrophy type 1 activity and participation scale (DM1-Activ). Neuromuscul Disord. 2010;20(5):310-8.

20. Hobart J, Cano S. Improving the evaluation of therapeutic interventions in multiple sclerosis: the role of new psychometric methods. Health Technol Assess. 2009;13(12):iii, ix-x, 1-177.

21. Vanhoutte EK, Faber CG, Merkies IS. 196th ENMC international workshop: Outcome measures in inflammatory peripheral neuropathies 8-10 February 2013, Naarden, The Netherlands. Neuromuscul Disord. 2013.

22. Heesch KC, Masse LC, Dunn AL. Using Rasch modeling to re-evaluate three scales related to physical activity: enjoyment, perceived benefits and perceived barriers. Health Educ Res. 2006;21 Suppl 1:i58-72.

23. Liang MH. Evaluating measurement responsiveness. J Rheumatol. 1995;22(6):1191-2.

24. van Nes SI, Faber CG, Merkies IS. Outcome measures in immune-mediated neuropathies: the need to standardize their use and to understand the clinimetric essentials. J Peripher Nerv Syst. 2008;13(2):136-47.

25. EuroQol--a new facility for the measurement of health-related quality of life. The EuroQol Group. Health Policy. 1990;16(3):199-208.

26. van der Beek NA, Hagemans ML, van der Ploeg AT, van Doorn PA, Merkies IS. The Rasch-built Pompe-specific activity (R-PAct) scale. Neuromuscul Disord. 2013;23(3):256-64. 
27. Herndon JE, II, Harrell FE, Jr. The restricted cubic spline hazard model. Comm Stat Theory Meth. 1990;19:639-63.

28. Kucukdeveci AA, Sahin H, Ataman S, Griffiths B, Tennant A. Issues in cross-cultural validity: example from the adaptation, reliability, and validity testing of a Turkish version of the Stanford Health Assessment Questionnaire. Arthritis and rheumatism. 2004;51(1):14-9.

29. Guillemin F, Bombardier C, Beaton D. Cross-cultural adaptation of health-related quality of life measures: literature review and proposed guidelines. Journal of clinical epidemiology. 1993;46(12):1417-32.

30. Andrich D. Relationships between the Thurstone and Rasch approaches to item scaling. Applied Psychological Measurement. 1978;2:449-60.

31. Andrich D, Sheridan B, Luo G. Rasch models for measurement: RUMM2030. Laboratory R, editor. Perth2010.

32. Lunn MP, Nobile-Orazio E. Immunotherapy for IgM anti-myelin-associated glycoprotein paraprotein-associated peripheral neuropathies. The Cochrane database of systematic reviews. 2012;5:CD002827.

33. Knutsson I, Rydstrom H, Reimer J, Nyberg P, Hagell P. Interpretation of response categories in patient-reported rating scales: a controlled study among people with Parkinson's disease. Health and quality of life outcomes. 2010;8:61.

34. Stucki G, Daltroy L, Katz JN, Johannesson M, Liang MH. Interpretation of change scores in ordinal clinical scales and health status measures: the whole may not equal the sum of the parts. J Clin Epidemiol. 1996;49(7):711-7.

35. Vanhoutte EK, Faber CG, van Nes SI, Jacobs BC, van Doorn PA, van Koningsveld R, et al. Modifying the Medical Research Council grading system through Rasch analyses. Brain : a journal of neurology. 2012;135(Pt 5):1639-49.

36. Hobart JC, Cano SJ, Zajicek JP, Thompson AJ. Rating scales as outcome measures for clinical trials in neurology: problems, solutions, and recommendations. Lancet neurology. 2007;6(12):1094105.

37. Grimby G, Tennant A, Tesio L. The use of raw scores from ordinal scales: time to end malpractice? J Rehabil Med. 2012;44(2):97-8.

38. Merbitz C, Morris J, Grip JC. Ordinal scales and foundations of misinference. Archives of physical medicine and rehabilitation. 1989;70(4):308-12.

39. Stevens SS. On the theory of scales of measurement. Science. 1946;103(2684):677-80.

40. Tubach F, Dougados M, Falissard B, Baron G, Logeart I, Ravaud P. Feeling good rather than feeling better matters more to patients. Arthrit Rheum-Arthr. 2006;55(4):526-30. 
\begin{tabular}{l|l} 
Rasch comparative responsiveness & 37
\end{tabular} 

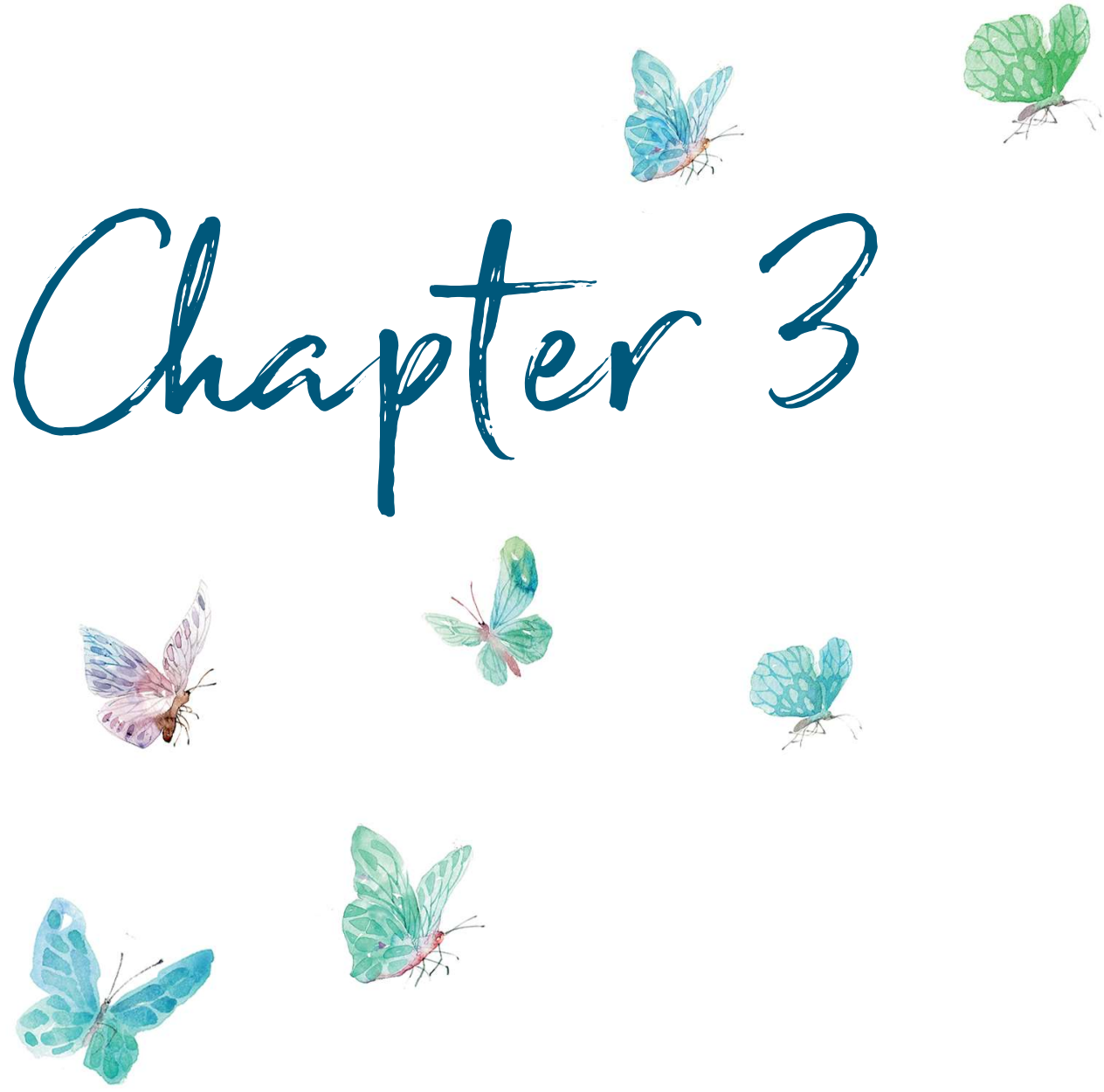


\section{Does ability to walk reflect general functionality in inflammatory neuropathies?}

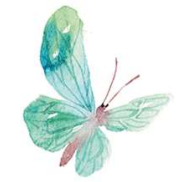

Thomas H. P. Draak, Kenneth C. Gorson, Els K. Vanhoutte, Sonja I. van Nes,

Pieter A. van Doorn, David R. Cornblath, Leonard H. van den Berg, Catharina G. Faber, Ingemar S. J. Merkies, and the PeriNomS Study Group

J Peripher Nerv Syst. 2016 Jun;21(2):74-81 


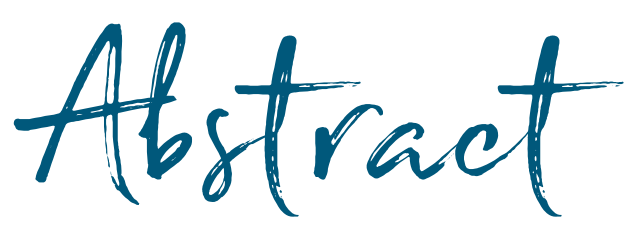

\section{BACKGROUND}

The "ability to walk" is considered a benchmark for good clinical recovery and prognosis, particularly in patients with Guillain-Barré syndrome (GBS) and chronic inflammatory demyelinating polyradiculoneuropathy (CIDP). However, it has never been determined whether being "able to walk" represents general functionality.

\section{OBJECTIVE}

To examine whether the ability to walk outside independently reflects general functional improvement in patients with GBS, CIDP, and IgM-monoclonal gammopathy of undetermined significance-related polyneuropathy (MGUSP).

\section{METHODS}

A total of 137 patients with newly diagnosed (or relapsing) GBS (55), CIDP (59), and MGUSP (23) were serially examined (1-year). Predefined arbitrary cut-offs (socalled patients' Functional-Acceptable-Clinical-Thresholds [FACTs]) were taken at the $50^{\text {th }}, 75^{\text {th }}$, and $90^{\text {th }}$ percentile of the Inflammatory-Rasch-built-Overall-DisabilityScale (I-RODSC). We determined the proportion of patients able to walk outside independently that reached the postulated cut-offs.

\section{RESULTS}

A mean total of $85 \%, 39 \%$, and $12 \%$ of all patients able to walk reached $50^{\text {th }}, 75^{\text {th }}$, and $90^{\text {th }}$ percentile thresholds, respectively. These findings were not neuropathy type related.

\section{CONCLUSION}

Our findings show that assessing only one construct of functionality (e.g. walking ability) does not reflect the full scope of daily/social functional deficits perceived by patients. The ability to walk shows a patient is doing better, but not necessarily doing well. The I-RODS@ bypasses these limitations. 


\section{INTRODUCTION}

Simplifying functional assessment to one construct, for example, the ability to walk 10 meters or outside, has been applied in inflammatory neuropathy studies and used as an outcome measure as well as a benchmark for a "good" prognosis.(1-12) Although this approach seems attractive, dichotomizing an outcome measure has major limitations: it may lead to data reduction, causing relevant information to be lost due to a lack of more comprehensive attention for the quality of interest and also leads to a reduction of scale's increments, for example by reducing the thresholds seen in a wider outcome measure to only one cut-off point, which on its turn may influence the sensitivity of a measure used in clinical studies.(13)

In patients with inflammatory neuropathies, (distal) weakness and sensory deficits have a major impact on activities of daily living, social functioning and quality of life. (14) We hypothesized that limiting functional assessment in these conditions to only 'the ability to walk 10 meters or outside' would not capture many of the disabilities experienced by the patients in daily lives arising from deficit related to upper limb dysfunction.

Recently, the Inflammatory-Rasch-built-Overall-Disability-Scale (I-RODS ${ }^{\odot}$, previously named the RODS) proved to be the best disease-specific surrogate outcome measure to assess activity limitations and participation restrictions in patients with Guillain-Barré syndrome (GBS), chronic inflammatory demyelinating polyneuropathy (CIDP) and IgM-monoclonal gammopathy of undetermined significance-related polyneuropathy (MGUSP) and has fulfilled all modern clinimetric requirements including its higher ability to capture clinical relevant changes over time when compared with traditional measures used in these conditions.(15-17) The I-RODS ${ }^{\odot}$ represents the patient's selection of everyday activities reflecting general functionality, We investigated whether the ability to walk outside independently, a measure within the frequently used INCAT disability scale in inflammatory neuropathies, would reflect general functionality.(4) To answer this question, we determined the proportion of serially examined patients with GBS, CIDP, and MGUSP being able to walk independently outside that reached arbitrarily predefined cut-offs at the $50^{\text {th }}, 75^{\text {th }}$, and $90^{\text {th }}$ percentile on the I-RODS ${ }^{\odot}$ as proposed by the investigators of the Peripheral Neuropathy Outcome Measures Standardization (PeriNomS) study group for comparison purposes. These cut-offs were named "Functional Acceptable Clinical Thresholds (FACTs)". If the ability to walk would represent general daily/social functioning, patient able to walk should reach a high score on the I-RODS ${ }^{\odot}$, thus reaching a high FACT. We hypothesized that the ability to walk would not reach high FACTs as it is limited to measuring only one construct. 


\section{METHODS}

\section{Patients, Eligibility, and Ethical aspects}

General characteristics, inclusion/exclusion criteria, and ethical approval of the 137 patients enrolled have been recently published.(17) In brief, 55 patients with GBS, 59 with CIDP, and 23 with MGUSP with newly diagnosed (or relapsing) neuropathy were examined prospectively over 1-year (GBS/CIDP examined at T0/T1/T3/T6/ T12 months; MGUSP at T0/T3/T12)

Patients were recruited and treated at the discretion of their physician at 26 international neuromuscular centers as part of the PeriNomS study.(16) All patients were $\geq 18$ years and fulfilled their illness criteria. Exclusion criteria were other potential causes for polyneuropathy, family history of neuropathy, exposure to neurotoxic medication or alcohol abuse.(17) The local medical ethics committee in each participating center approved the protocol. All patients provided written informed consent.

\section{Study design and Assessments}

The INCAT disability scale is an ordinal-based metric that assesses upper and lower extremity function, of which the latter is examined by determining the ability to walk outside independently or with an aid. The I-RODS ${ }^{\oplus}$ contains 24 activity/participation items graded from easy to difficult to perform $(4,15)$. These outcome measures were assessed in random order. Using the predefined FACTs on the I-RODS ${ }^{\odot}$, we were able to determine what a patient with the ability to walk independently could most probably do if the $50^{\text {th }}, 75^{\text {th }}$, or $90^{\text {th }}$ cut-offs was reached: reaching the $50^{\text {th }}$ percentile, the patient would most probably have no difficulty reading, eating, brushing teeth, washing upper/lower body or taking a shower, going to a toilet, making a sandwich, dressing upper body, or turn a key in a lock. In addition, those who reached the $75^{\text {th }}$ percentile would most probably also be able to go to a general practitioner, do the dishes, go shopping, travel by public transportation, walk while avoiding obstacles, walk a flight of stairs, and even walk up to $1 \mathrm{~km}$ outside. Finally, those reaching the $90^{\text {th }}$ percentile would be able to carry and put down a heavy object and dance, but may have difficulty standing for hours and running.(15)

\section{Statistics}

To examine whether having the ability to walk outside represents general daily/social activities, we arbitrarily chose FACTs at the $50^{\text {th }}, 75^{\text {th }}$ and $90^{\text {th }}$ percentile on the I-RODS ${ }^{\odot}$ and determined the proportion of the patients who were able to walk outside independently that reached these cut-offs. We subsequently compared 
the proportion of patients reaching the $50^{\text {th }}$ versus the $75^{\text {th }}$ and $90^{\text {th }}$ percentiles, at the disease level ( $\mathrm{X}^{2}$-statistics). Finally, we examined whether the severity of being ill would be of any influence reaching the FACTs.(15) The severity of being ill is defined as the degree of functional deficit experienced by patients and is based on the calculated tertiles of baseline I-RODS ${ }^{\odot}$ scores; $1^{\text {st }}$ tertile: lowest one-third scores on the original I-RODS ${ }^{\oplus}$ values (most severely affected patients; these patients would most probably be able to read, eat, brush teeth, wash upper body, go to the toilet, make a sandwich, dress upper body, wash lower body, move a chair, turn a key in a lock, go to the general practitioner, take a shower, and do the dishes, but with difficulty); $2^{\text {nd }}$ tertile: mid-one-third portion (moderately affected, being able to perform without difficulty all of the above-mentioned tasks for the $1^{\text {st }}$ tertile patients plus go shopping, catch an object (e.g. a ball), bend over and pick up an object from the floor, walk one flight of stairs, travel by public transport, and walking and avoiding obstacles); and $3^{\text {rd }}$ tertile: highest one-third portion (least affected patients, being additionally able to walk outside up to $1 \mathrm{~km}$, able to carry and put down a heavy object (around $10 \mathrm{~kg}$ ), and able to dance, but will have difficulty standing for hours and running). All analyses were undertaken using Stata 13.0 for Windows and a significant p-value was set at 0.05 .

\section{RESULTS}

\section{General Characteristics}

Patients' characteristics are presented in Table 1 . Most patients received treatment (GBS: 93\%, CIDP: 71\%, MGUSP: 50\%). Intravenous immunoglobulin (IVIg) was prescribed most commonly (in GBS: $82 \%$, CIDP: 53\%, MGUSP: $35 \%$ ); steroids were used either in combination with IVIg or alone (in GBS: 15\%, CIDP: 15\%). Plasma exchange was performed in 9 GBS cases (16\%), 3 CIDP (5\%), and in 4 MGUSP cases (17\%). Two patients with MGUSP received additional treatment with an immunosuppressant agent.

\section{Ability to walk versus Functional Acceptable Clinical Thresholds (FACTs)} The proportion of patients able to walk outside independently at entry and during follow-up is shown Figures $1 \mathrm{~A} / 1 \mathrm{C} / 1 \mathrm{E}$. At entry, $46 \%$ of patients with GBS were able to walk independently (for CIDP and MGUSP these percentages were $61 \%$ and $83 \%$, respectively). At 12 months, $75 \%$ of the patients with MGUSP, $86 \%$ with CIDP, and $88 \%$ with GBS were able to walk independently outside (Figure 1, $1 \mathrm{~A} / 1 \mathrm{C} / 1 \mathrm{E})$. 


\begin{tabular}{|c|c|c|c|}
\hline \multirow[b]{2}{*}{ IIIness } & \multicolumn{3}{|c|}{ All patients $(n=137)$} \\
\hline & GBS $(n=55)$ & $\operatorname{CIDP}(n=59)$ & MGUSP $(n=23)$ \\
\hline Age, mean $(S D)$, range & $53.4(17.7), 19-90$ & $52.7(14.7), 18-79$ & $62.8(10.6), 45-85$ \\
\hline \multicolumn{4}{|l|}{ Gender, n (\%) } \\
\hline Female & $18(32.7)$ & $17(28.8)$ & $8(34.8)$ \\
\hline Male & $37(67.3)$ & $42(71.2)$ & $15(65.2)$ \\
\hline \multicolumn{4}{|l|}{ Years since diagnosis } \\
\hline Mean (SD), range & - & $1.8(3.1), 0-16$ & $3.3(5.3), 0.2-25$ \\
\hline \multicolumn{4}{|l|}{ Tertiles on baseline I-RODS ${ }^{\bullet}$ scores (\%) } \\
\hline $1^{\text {st }}$ (most affected patients) & 46.9 & 15.7 & 0.0 \\
\hline $2^{\text {nd }}$ (moderate affected patients) & 51.0 & 54.9 & 54.5 \\
\hline $3^{\text {rd }}$ (least affected patients) & 2.1 & 29.4 & 45.5 \\
\hline
\end{tabular}

$\mathrm{SD}=$ standard deviation. GBS: Guillain-Barré syndrome, CIDP: chronic inflammatory demyelinating polyradiculoneuropathy; MGUSP: monoclonal gammopathy of undetermined significance-related polyneuropathy. I-RODS ${ }^{\bullet}$ Inflammatory Rasch-built overall disability scale.

We subsequently determined the relationship between the ability to walk outside independently and reaching the chosen $\mathrm{I}_{-\mathrm{RODS}^{\odot}}$ FACTs (Figure 1B/1D/1F). In GBS, we particularly saw within 3 months of onset an improvement in functionality, showing a gradual shift of the curve towards the right on the I-RODS ${ }^{\oplus}$ (Figure 1B). After this period, marginal changes were seen. Approximately $2 / 3$ of the GBS patients reached the $75^{\text {th }}$ cut-off on the I-RODS ${ }^{\odot}$, but only $15.6 \%$ and $36.6 \%$ reached the $90^{\text {th }}$ FACT at 6 and 12 months, respectively (Figure 1B). Projecting those being able to walk outside independently and having CIDP and MGUSP showed hardly any changes in general functionality during whole follow-up with a small proportion of patients reaching the $75^{\text {th }}$ and $90^{\text {th }}$ cut-offs (Figure $1 \mathrm{D} / 1 \mathrm{~F}$ ).

The mean pooled scores of all patients able to walk outside independently showed a gradual decrease in functionality after the $50^{\text {th }}$ percentile, with $85 \%, 39 \%$ and $12 \%$ of all patients being able to walk reaching the $50^{\text {th }}, 75^{\text {th }}$ and $90^{\text {th }}$ FACTs at 12 months follow-up, respectively (proportion of patients reaching the $75^{\text {th }}$ and $90^{\text {th }}$ versus $50^{\text {th }}$ at 12 months: for both comparisons: $\mathrm{p}<0.001)$. Similar findings were observed at the disease level (Figure 1B/1D/1F)

\section{Tertiles of baseline I-RODS@ scores versus the FACTs}

At study entry, a total of $25.4 \%$ of all patients had low scores corresponding to the $1^{\text {st }}$ tertile (most severely affected patients); $53.3 \%$ and $21.3 \%$ represented the $2^{\text {nd }}$ (moderately affected) and $3^{\text {rd }}$ (least affected) tertiles, respectively. The tertiles distribution at baseline for each illness is presented in table 1. Mobility was 


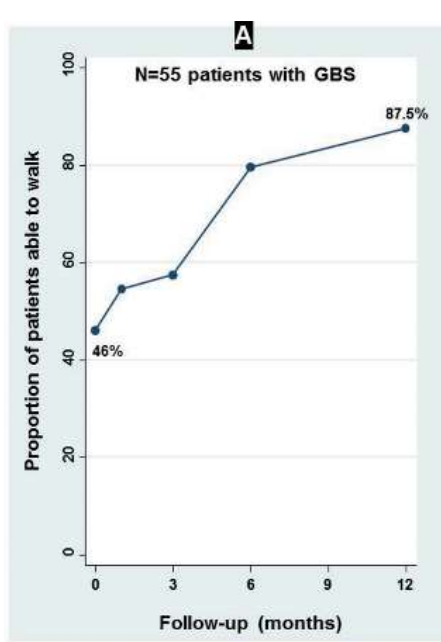

Follow-up (months)

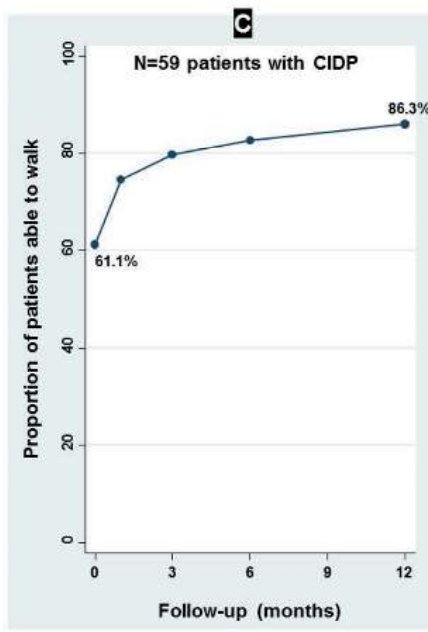

\section{目}

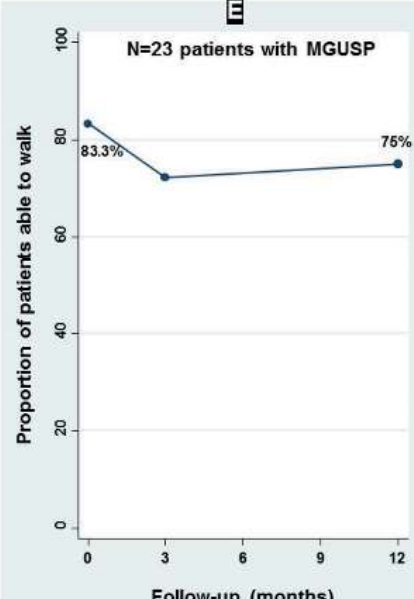

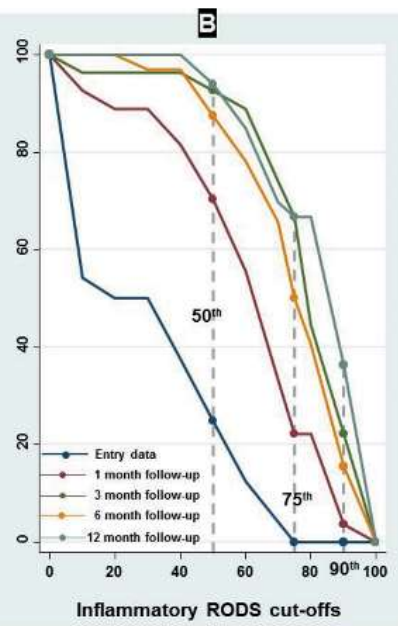



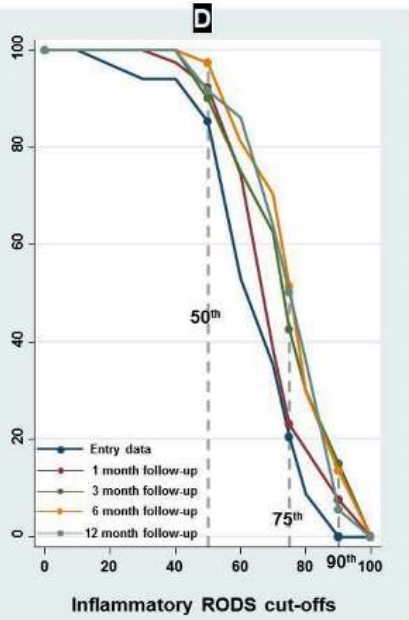

a

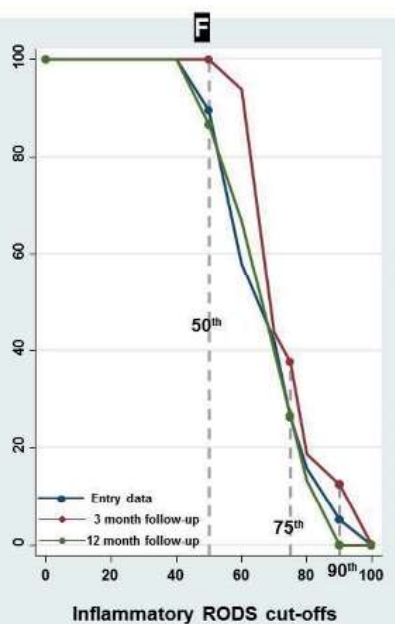

FIGURE 1.

Ability to walk outside independently related to FACTs on the I-RODS $\odot$. The top graphs are for the patients with Guillain-Barré syndrome (GBS); the middle graphs are for patients having chronic inflammatory demyelinating polyradiculoneuropathy (CIDP), the bottom graphs are for patients having IgM-monoclonal gammopathy of undetermined significance-related polyneuropathy (MGUSP).

I-RODS@, inflammatory Raschbuilt overall disability scale; FACTs, functional acceptable clinical thresholds, arbitrarily defined cut-offs on the I-RODS $\odot$ 
particularly affected in the lowest $\left(1^{\text {st }}\right)$ tertile, while almost all patients in the highest tertile maintained their ability to walk $10 \mathrm{~m}$ without aid from entry to 12 -months follow-up (Figure 2A).

As illustrated in Figure $2 \mathrm{~B}$, less than $1 / 4$ of the patients being able to walk $10 \mathrm{~m}$ without aid, representing the $1^{\text {st }}$ and $2^{\text {nd }}$ tertiles, reached the $75^{\text {th }}$ cut-off ( $1^{\text {st }}$ tertile: $\left.11 \%, 2^{\text {nd }} ; 24.2 \%\right)$; for the $3^{\text {rd }}$ tertile, slightly more than half of the patients $(57.7 \%)$ reached the $75^{\text {th }}$ FACT. However, the mean scores were extremely low at the $90^{\text {th }}$ cut-off ( $1^{\text {st }}$ tertile: $2.4 \%, 2^{\text {nd }}$ tertile: $9.1 \%, 3^{\text {rd }}: 12.4 \%$, Figure $\left.2 B\right)$.

\section{DISCUSSION}

In this study we have demonstrated that despite having or recovering the ability to walk outside independently, most patients with GBS, CIDP, and MGUSP still showed poor general functionality as assessed with the I-RODS ${ }^{\odot}$. This seems to correlate with our initial hypothesis: limiting functional assessment to only one construct will not capture the whole spectrum of functional limitations perceived by these patients in daily and social practice. An overall total of $61 \%$ and $88 \%$ of all patients did not reach the $75^{\text {th }}$ and $90^{\text {th }}$ cut-offs on the I-RODS ${ }^{\odot}$. Our data indicate that the ability to walk inadequately captures the full scope of activity limitations and participation restrictions as perceived by patients. As a result, future clinical trials in patients with inflammatory neuropathies that do not use outcome measures with a larger array of functional abilities (such as I-RODS ${ }^{\odot}$ ) may inappropriately conclude a treatment being effective, because the patient recovered to walk outside independently. In fact, the patient is indeed "doing better" (as demonstrated in Figure 1A), but is not necessarily "doing well".(18, 19) From another perspective, by including only patients who aren't able to walk, we might bypass those who still experience substantial functional limitations despite their ability to walk outside independently as shown by the I-RODS ${ }^{\odot}$ findings illustrated in Figure 1B, entry findings (see blue line). Future studies in patients with "mildly" affected GBS could be of great value to examine these observations. (20)

The findings in the current study also tell us that trials in GBS should be performed over a longer period, enabling us to capture changes in contrast with the outcome set in previous trials at 4 weeks after starting therapy and using a more comprehensive scale as the primary outcome measure instead of a single construct approach. $(8,21)$ Despite the improvement seen in GBS, most patients remain functionally limited (Figure 1B). In addition, those being treated for CIDP and MGUSP benefit only slightly from a functional perspective as illustrated in Figures 

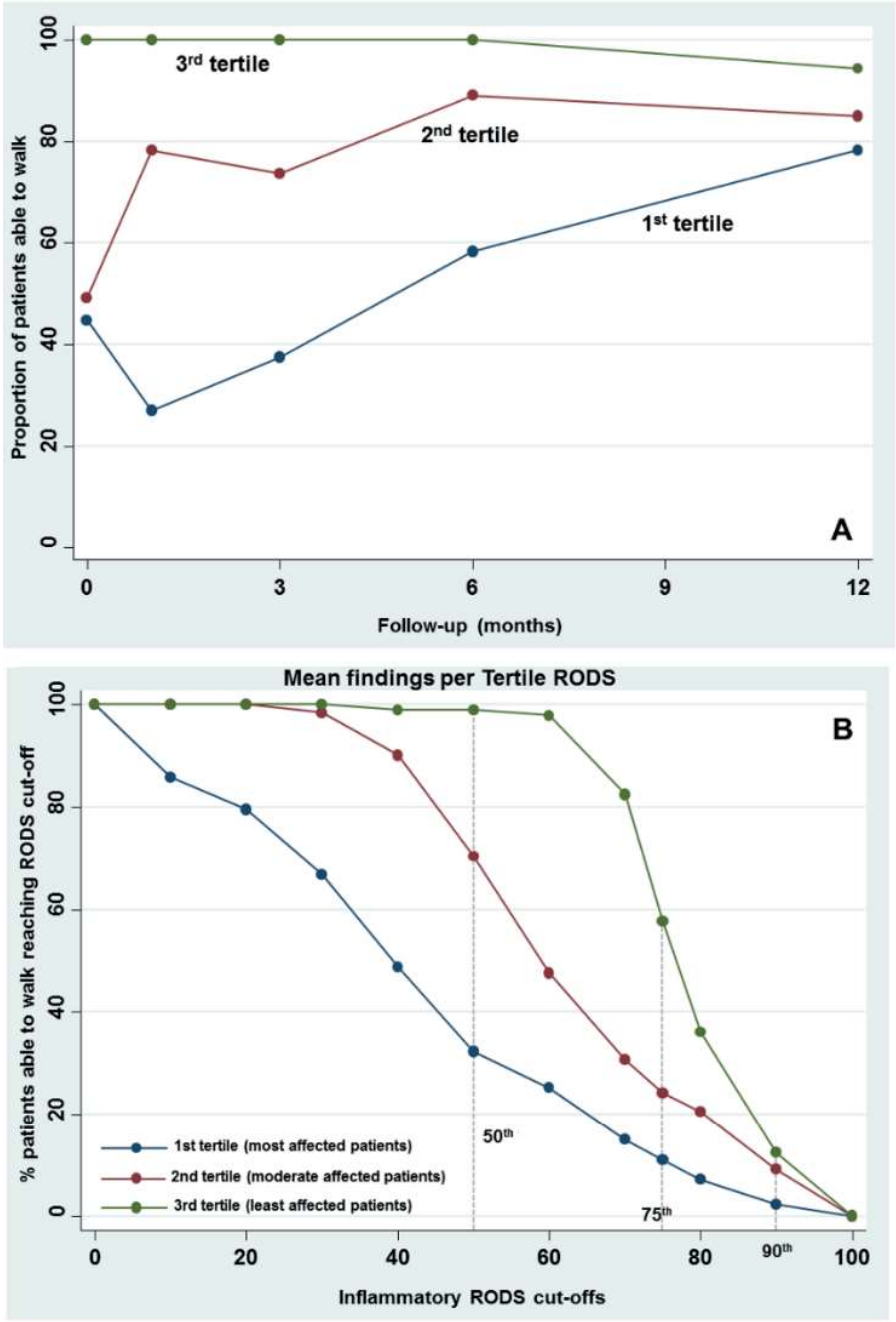

FIGURE 2. Patients' distribution across tertiles of the I-RODS $\odot$ baseline scores related to ability to walk independently outside and FACTs on the I-RODS৫ .

(A) The proportion of patients being able to walk outside independently in relation to their distribution across the three tertiles calculated using the I-RODS $\odot$ baseline scores. (B) The pooled data of patients per tertile, being able to walk independently outside that reached the predefined FACTs on the I-RODS $\odot$. As can be seen, most patients, irrespective of which tertile they belong, did not reach the 90th FACT cut-off. I-RODS $\odot$, inflammatory Rasch-built overall disability scale; FACTs, functional acceptable clinical thresholds, arbitrarily defined cut-offs on the I-RODS๑.

$1 \mathrm{D}$ and $1 \mathrm{~F}$; showing no rigorous changes in their functionality score over 12 months follow-up. However, these findings should be validated in a larger cohort of patients. Efforts are currently being undertaken to accomplish this through ongoing registries in these conditions. 
Furthermore, therapeutic trials in inflammatory neuropathies have not differentiated between lower or upper limb functions in regards of measuring the effects of their therapy and focused mainly on mobility aspects. It could be worth exploring if there is a difference between regaining function in lower or upper limb after immunomodulatory therapy. However, the I-RODS ${ }^{\odot}$ represents a more integrative approach to functionality in these conditions blending upper and lower limb related deficits through its items, an approach that is not captured through a single construct like being able to walk or not independently.

Tubach and colleagues stated that patients "may only report a major improvement when they perceive their health state as satisfactory". $(18,22)$ To capture this, they have introduced the concept of Patient's Acceptable Symptom State (PASS), defined as the value, based on patient's perspective, "where patients consider themselves well". $(18,22)$ The FACTs used in the current study differ from the PASS concept, since the former were arbitrarily taken by physicians, where PASS cut-offs on a scale of interest are obtained through interviewing patients. The next logical steps are being taken to determine the real I-RODS ${ }^{\odot}$ cut-offs through patients' interviews as suggested by Tubach and colleagues.(22) Once defined, these thresholds could be integrated in future interventional trials in these disorders to determine the patients who really achieved a "satisfactory health state", hereby helping physicians to target a multi-functional domain rather than a single-endpoint construct like the ability to walk. 


\section{REFERENCES}

1. Hahn AF, Bolton CF, Zochodne D, Feasby TE. Intravenous immunoglobulin treatment in chronic inflammatory demyelinating polyneuropathy. A double-blind, placebo-controlled, crossover study. Brain : a journal of neurology. 1996;119 ( Pt 4):1067-77.

2. Thompson N, Choudhary P, Hughes RA, Quinlivan RM. A novel trial design to study the effect of intravenous immunoglobulin in chronic inflammatory demyelinating polyradiculoneuropathy. J Neurol. 1996;243(3):280-5.

3. Hadden RD, Sharrack B, Bensa S, Soudain SE, Hughes RA. Randomized trial of interferon beta$1 \mathrm{a}$ in chronic inflammatory demyelinating polyradiculoneuropathy. Neurology. 1999;53(1):5761.

4. Hughes R, Bensa S, Willison H, Van den Bergh P, Comi G, Illa I, et al. Randomized controlled trial of intravenous immunoglobulin versus oral prednisolone in chronic inflammatory demyelinating polyradiculoneuropathy. Annals of neurology. 2001;50(2):195-201.

5. Wollinsky KH, Hulser PJ, Brinkmeier H, Aulkemeyer P, Bossenecker W, Huber-Hartmann KH, et al. CSF filtration is an effective treatment of Guillain-Barre syndrome: a randomized clinical trial. Neurology. 2001;57(5):774-80.

6. Comi G, Roveri L, Swan A, Willison H, Bojar M, Illa I, et al. A randomised controlled trial of intravenous immunoglobulin in IgM paraprotein associated demyelinating neuropathy. J Neurol. 2002;249(10):1370-7.

7. Pritchard J, Gray IA, Idrissova ZR, Lecky BR, Sutton IJ, Swan AV, et al. A randomized controlled trial of recombinant interferon-beta 1a in Guillain-Barre syndrome. Neurology. 2003;61(9):12824.

8. van Koningsveld R, Schmitz PI, Meche FG, Visser LH, Meulstee J, van Doorn PA, et al. Effect of methylprednisolone when added to standard treatment with intravenous immunoglobulin for Guillain-Barre syndrome: randomised trial. Lancet. 2004;363(9404):192-6.

9. Korinthenberg R, Schess J, Kirschner J, Monting JS. Intravenously administered immunoglobulin in the treatment of childhood Guillain-Barre syndrome: a randomized trial. Pediatrics. 2005;116(1):8-14.

10. El-Bayoumi MA, El-Refaey AM, Abdelkader AM, El-Assmy MM, Alwakeel AA, El-Tahan HM. Comparison of intravenous immunoglobulin and plasma exchange in treatment of mechanically ventilated children with Guillain Barre syndrome: a randomized study. Crit Care. 2011;15(4):R164.

11. Markvardsen LH, Debost JC, Harbo T, Sindrup SH, Andersen H, Christiansen I, et al. Subcutaneous immunoglobulin in responders to intravenous therapy with chronic inflammatory demyelinating polyradiculoneuropathy. Eur J Neurol. 2013;20(5):836-42.

12. Hughes RA, Newsom-Davis JM, Perkin GD, Pierce JM. Controlled trial prednisolone in acute polyneuropathy. Lancet. 1978;2(8093):750-3 
13. Hobart JC, Cano SJ, Zajicek JP, Thompson AJ. Rating scales as outcome measures for clinical trials in neurology: problems, solutions, and recommendations. The Lancet Neurology. 2007;6(12):1094-105.

14. van den Berg B, Walgaard C, Drenthen J, Fokke C, Jacobs BC, van Doorn PA. GuillainBarre syndrome: pathogenesis, diagnosis, treatment and prognosis. Nature reviews Neurology. 2014;10(8):469-82.

15. van Nes SI, Vanhoutte EK, van Doorn PA, Hermans M, Bakkers M, Kuitwaard K, et al. Raschbuilt Overall Disability Scale (R-ODS) for immune-mediated peripheral neuropathies. Neurology. 2011;76(4):337-45.

16. Vanhoutte EK, Faber CG, Merkies IS. 196th ENMC international workshop: Outcome measures in inflammatory peripheral neuropathies 8-10 February 2013, Naarden, The Netherlands. Neuromuscul Disord. 2013;23(11):924-33.

17. Draak TH, Vanhoutte EK, van Nes SI, Gorson KC, Van der Pol WL, Notermans NC, et al. Changing outcome in inflammatory neuropathies: Rasch-comparative responsiveness. Neurology. 2014;83(23):2124-32.

18. Tubach F, Wells GA, Ravaud P, Dougados M. Minimal clinically important difference, low disease activity state, and patient acceptable symptom state: methodological issues. The Journal of rheumatology. 2005;32(10):2025-9.

19. Tubach F, Dougados M, Falissard B, Baron G, Logeart I, Ravaud P. Feeling good rather than feeling better matters more to patients. Arthritis and rheumatism. 2006;55(4):526-30.

20. Green DM, Ropper AH. Mild Guillain-Barre syndrome. Archives of neurology. 2001;58(7):1098101.

21. van der Meche FG, Schmitz PI. A randomized trial comparing intravenous immune globulin and plasma exchange in Guillain-Barre syndrome. Dutch Guillain-Barre Study Group. N Engl J Med. 1992;326(17):1123-9.

22. Pham T, Tubach F. Patient acceptable symptomatic state (PASS). Joint, bone, spine : revue du rhumatisme. 2009;76(4):321-3. 
\begin{tabular}{l|l} 
Ability to walk & 51
\end{tabular} 

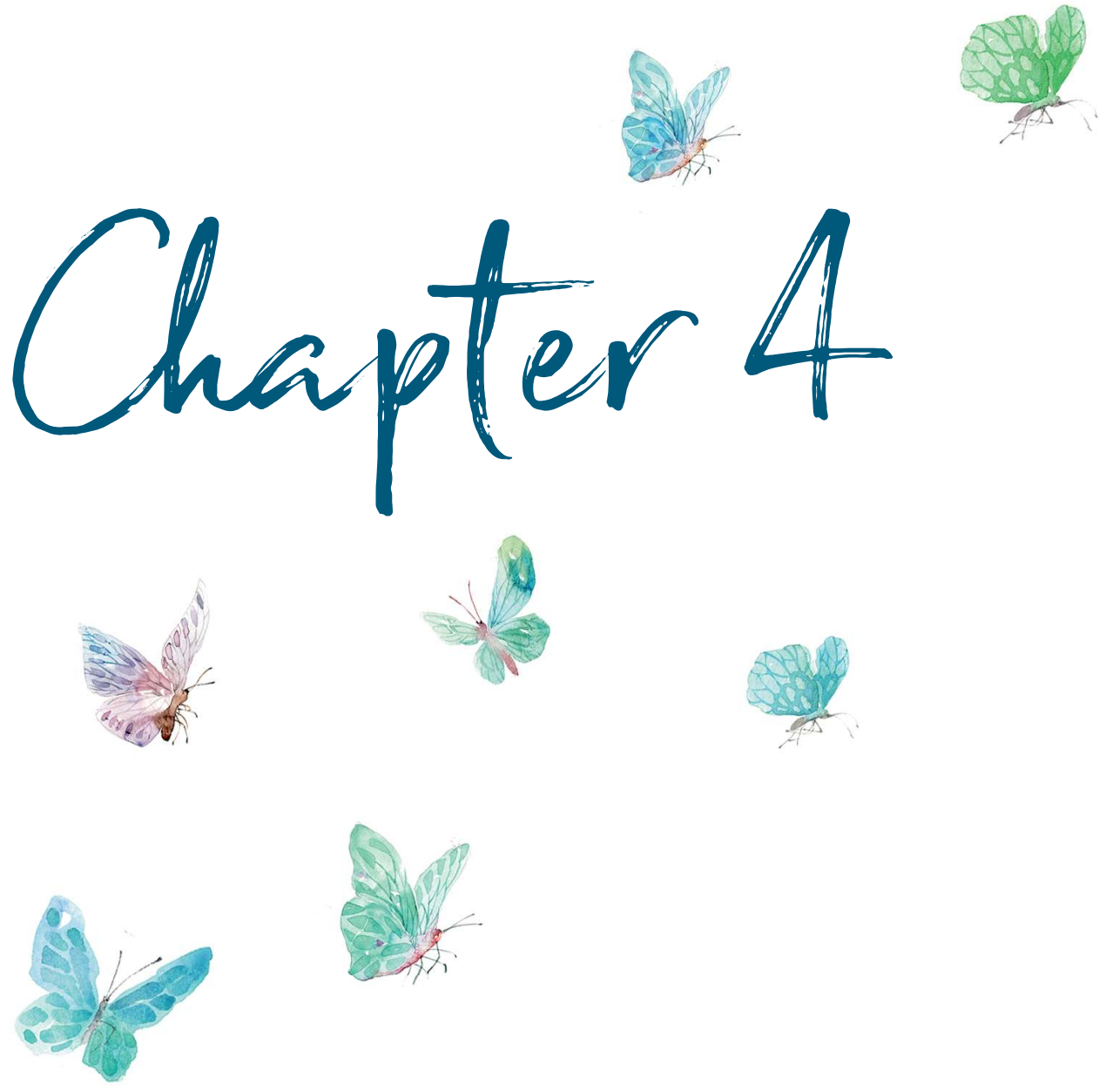


\title{
Correlation of the patient's reported outcome Inflammatory-RODS with an objective metric in immune-mediated neuropathies
}

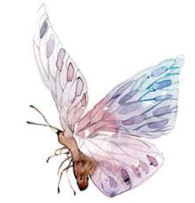

\author{
T. H. P. Draak, K. C. Gorson, E. K. Vanhoutte, S. I. van Nes, P. A. van Doorn, \\ D. R. Cornblath, L. H. van den Berg, C. G. Faber and I. S. J. Merkies for the PeriNomS \\ Study Group
}

Eur J Neurol. 2016 Jul;23(7):1248-53 


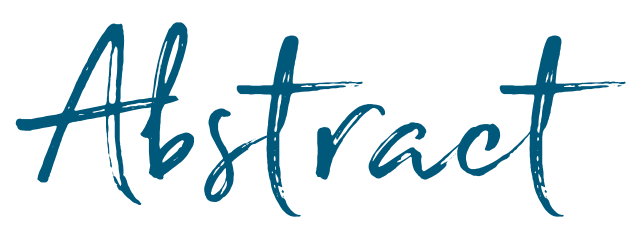

\section{BACKGROUND}

There is increasing interest in using patient-reported outcome measures (PROMs) in clinical studies to capture individual changes over time. However, PROMs also have been criticized because they are entirely subjective.

\section{OBJECTIVE}

To examine the relationship between a subjective PROM and an objective outcome tool in patients with Guillain-Barré syndrome (GBS), chronic inflammatory demyelinating polyradiculoneuropathy (CIDP) and monoclonal gammopathy of undetermined significance-related polyneuropathy (MGUSP).

\section{METHODS}

The Inflammatory Rasch-built Overall Disability Scale (I-RODS@: a multi-item scale that examines functionality) was completed by 137 patients with newly diagnosed (or relapsing) GBS (55), CIDP (59), and MGUSP (23) who were serially examined (GBS/CIDP: T0/T1/T3/T6/T12 months; MGUSP: T0/T3/T12). Possible association between the I-RODS findings and the Vigorimeter scores, an objective linear instrument to assess grip strength, was examined.

\section{RESULTS}

A significant correlating trend was found between the I-RODS and grip strength scores for the overall group and in each illness, independently.

\section{CONCLUSION}

The objectivity of patients' subjective report on their functional state based on a strong correlation between the I-RODS and grip strength in patients with GBS, CIDP and MGUSP has been demonstrated. These findings provide further support to use the I-RODS and grip strength in future clinical studies in these conditions. 


\section{INTRODUCTION}

Patient-reported outcome measures (PROMs) are used frequently as endpoints in clinical trials and outcome studies. $(1,2)$ PROMs are measurements of a patient's health condition obtained directly from the patient's own judgement, thus capturing their voice without input from a clinician. However, the use of these subjective outcome measures is controversial, and there are concerns about their validity, reliability and objectivity, as well as other factors. (3-10)One of the major criticisms for PROMs is their lack of objectivity, i.e., the ability to accurately reflect what they purport to measure and independently correlate with other unbiased outcome measures, and therefore many investigators have been reluctant to their use in clinical studies. Furthermore, there are virtually no studies that have systematically examined the objectiveness of a PROM in peripheral neuropathies.

The Inflammatory Rasch-built Overall Disability Scale (I-RODS $\left.{ }^{\odot}\right)$ is a PROM that has been demonstrated to be the best surrogate outcome measure to assess activity limitations and participation restrictions in patients with Guillain-Barré syndrome (GBS), chronic inflammatory demyelinating polyneuropathy (CIDP) and IgMmonoclonal gammopathy of undetermined significance-related polyneuropathy (MGUSP). (11-13) The I-RODS ${ }^{\odot}$ represents the patient's selection of everyday activities reflecting general functionality. In contrast to the subjective I-RODS ${ }^{\odot}$, the Vigorimeter is an objective metric that assesses grip strength, and it has been demonstrated to be a precise linear measure that is highly sensitive in capturing changes over time in these patients, despite being criticized not being reliable enough to assess responsiveness. (14-17) Our study was designed to examine the objectivity of patients' subjective reporting of their functional status in patients with inflammatory neuropathies. $(11,18)$ We hypothesized that the I-RODS ${ }^{\odot}$ would show a strong correlation with grip strength, thus demonstrating indirectly the objectivity of this patient reported outcome measure. (15)

\section{METHODS}

\section{Patients, Eligibility, and Ethical aspects}

General characteristics, inclusion/exclusion criteria and ethical approval of the 137 patients enrolled have been published. (13) Briefly, 55 patients with GBS, 59 with CIDP, and 23 with MGUSP with a newly diagnosed (or relapsing) neuropathy were examined prospectively over 12 months (Table 1 ). 
TABLE 1: Characteristics of study population.

\begin{tabular}{lccc} 
& \multicolumn{3}{c}{ All patients $(\mathrm{n}=137)$} \\
\cline { 2 - 4 } Illness & GBS $(\mathrm{n}=55)$ & $\mathrm{CIDP}(\mathrm{n}=59)$ & MGUSP $(\mathrm{n}=\mathbf{2 3})$ \\
\hline Age, mean (SD), range & $53.4(17.7), 19-90$ & $52.7(14.7), 18-79$ & $62.8(10.6), 45-85$ \\
Gender, $\mathrm{n}(\%)$ & & & \\
$\quad$ Female & $18(32.7)$ & $17(28.8)$ & $8(34.8)$ \\
$\quad$ Male & $37(67.3)$ & $42(71.2)$ & $15(65.2)$ \\
Years since diagnosis & - & & \\
Mean (SD) & - & $1.8(3.1)$ & $3.3(5.3)$ \\
Range & - & $0-16$ & $0.2-25$ \\
\hline
\end{tabular}

$\mathrm{SD}=$ standard deviation. GBS: Guillain-Barré syndrome, CIDP: chronic inflammatory demyelinating polyradiculoneuropathy; MGUSP: IgM monoclonal gammopathy of undetermined significance related polyneuropathy.

GBS and CIDP patients were examined at T0, T1, T3, T6, and T12 months, and for patients with MGUSP, at T0, T3, and T12 months, based on the indolent course of the latter illness. Patients were recruited and treated at the discretion of their physician as part of the Peripheral Neuropathy Outcome Measures Standardization (PeriNomS) study. (19) All patients were 18 years or older and met the international criteria for their illness. (20-22) Patients were excluded if they had any other potential cause for polyneuropathy, family history of neuropathy or exposure to neurotoxic medication or alcohol abuse. (19)

Patients were recruited during hospital admission or at outpatient clinics at 26 international neuromuscular centers in the USA (Boston and Detroit), Canada (Ontario and Toronto), Brazil (Ribeiráo Preto), United Kingdom (London), Italy (Milan, Rome, and Venice), France (Paris and Marseille), Spain (Barcelona), Belgium (Brussels), and the Netherlands (Maastricht, Amsterdam, Utrecht, and Rotterdam). The local medical ethics committee in each participating center approved the protocol. Written informed consent was obtained from all participants.

\section{Study design and Assessments}

\section{Patients' report on outcome}

The I-RODS ${ }^{\odot}$ contains 24 activity and participation items graded from easy to difficult (able to read a newspaper/book [easiest item] up to being able to run [most difficult item]) (see Supplemental table 1). (11) Verbal and written instructions were provided to the researchers and patients on how to respond to the questions regarding the outcome measures. The I-RODS ${ }^{\odot}$ raw findings were subsequently transformed into Logits, the fixed unit used by Rasch analysis before further data analyses took place. (11) 


\section{Grip strength assessment}

All researchers were trained how to perform and record the findings of the Vigoridynamometer (0-160 kPa) in a standardized manner. Also, a picture-enriched training manual was provided that demonstrated the appropriate methods of data collection to each participating institute as part of the PeriNomS study. (19) Grip strength was assessed at each visit three times for both hands in an alternating order with 30 seconds rest in between, and the mean of the assessments for each hand was calculated.

\section{Statistics}

The correlation between the subjective I-RODS ${ }^{\odot}$ and the objective grip strength was examined using random effects linear regression analyses, taking into account the association of the data caused by the longitudinal structure. The latter was achieved using the program "xtreg" in STATA 13.0 for Windows XP, which is based upon a time-series regression model as described by Dwyer and Feinleib. (23) The strength of association between the variables was expressed as $R^{2}$ : the fraction of variance explained by the independent variable (changes in inflammatory-RODS) on the dependent variable (grip strength) + 'time'-factor from the regression model. All analyses were undertaken using Stata 13.0 for Windows.

\section{RESULTS}

\section{General Characteristics}

Patients' characteristics are presented in Table 1 . Most patients received treatment (93\% in GBS, 71\% in CIDP and 50\% in MGUSP). Intravenous immunoglobulin (IVIg) was prescribed most commonly (82\% in GBS, 53\% in CIDP and 35\% in MGUSP); corticosteroids were used either in combination with IVIg or alone (15\% in GBS and $15 \%$ in CIDP). Plasma exchange was performed in 9 GBS cases (16\%), 3 CIDP (5\%), and in 4 MGUSP cases (17\%). A small number was treated with an immunosuppressant agent ( 2 cases with MGUSP received cyclophosphamide; 1 patient with MGUSP was treated with azathioprine). A total of 600 patient visits were completed over 12 months follow-up. The data obtained at these visits were pooled to determine the correlation findings between the grip strength and I-RODS ${ }^{\odot}$.

\section{Grip strength in relation to I-RODS ${ }^{\odot}$}

Both assessments had acceptable normal distribution pattern. There was a significant correlation between grip strength values and the functional categories of the I-RODS ${ }^{\odot}$ (Figure). The correlation was most clear for GBS followed by CIDP and MGUSP patients. Quite similar patterns were seen between right and left hand grip strength scores versus I-RODS ${ }^{\odot}$ categories (Figure 1). 

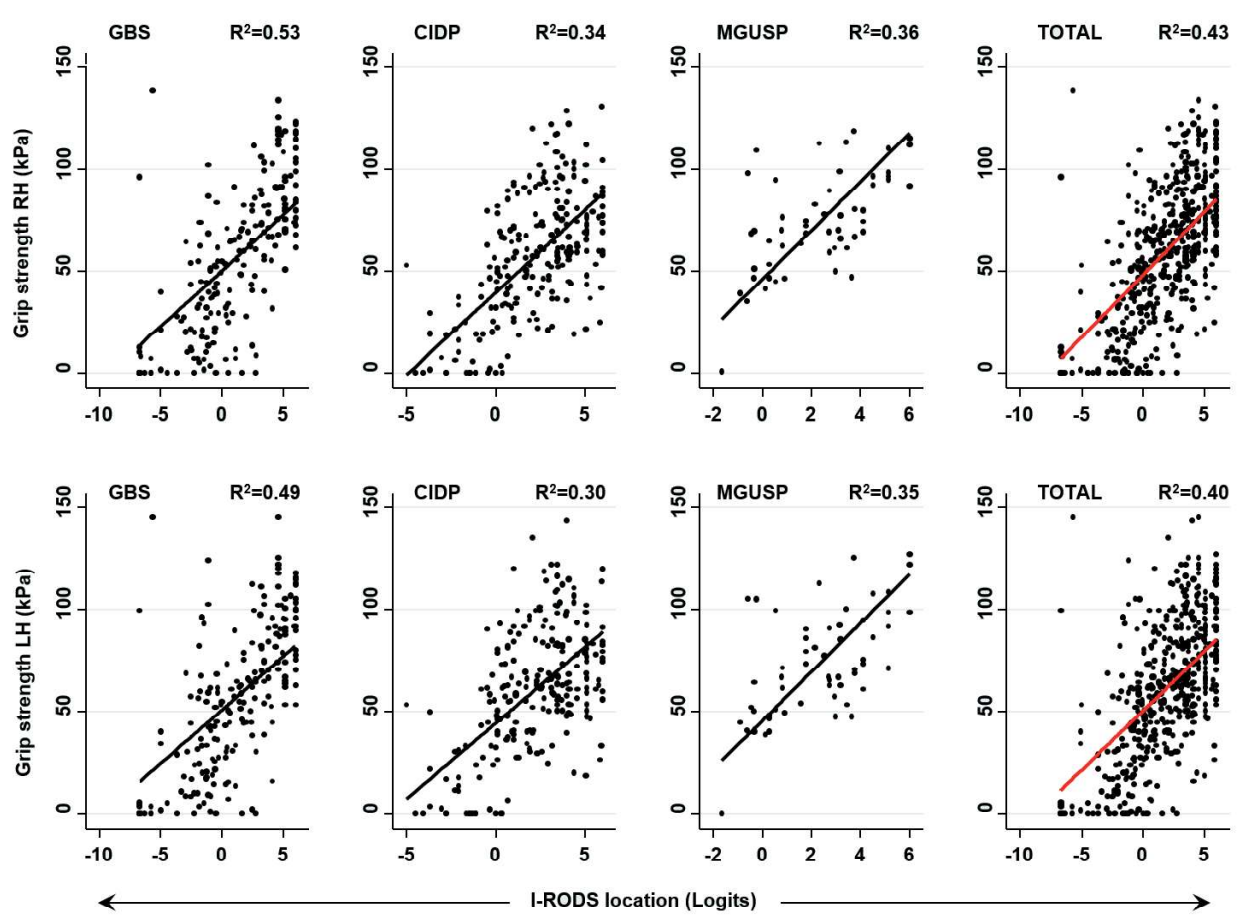

FIGURE 1: Association between grip strength ( $\mathrm{kPa}$ ) and I-RODS location (logits).

All patients were examined during 12 months; the obtained data for the assessments were pooled and used for correlation purposes. The association between the two variables was determined using regression studies, taking into account the clustering of data at the individual patient's level in time [23], and was expressed as $R^{2}$ : the fraction of variance explained by the independent variable (changes in inflammatory$\mathrm{RODS}$ ) on the dependent variable (grip strength) + 'time'-factor from the regression model; for all associations, $\mathrm{p} \leq 0.001$.

I-RODS $\odot$ : inflammatory Rasch-built overall disability scale; Top panels Right Hand $(\mathrm{RH})$ bottom panels, Left Hand (LH) GBS: Guillain-Barré syndrome ( $n=55$ patients), CIDP: chronic inflammatory demyelinating polyradiculoneuropathy ( $\mathrm{n}=59$ patients), MGUSP: IgM Monoclonal gammopathy of undetermined significance related polyneuropathy ( $n=23$ patients).

\section{DISCUSSION}

In this study we have demonstrated that a patients' own (subjective) personal report on executing daily/social activities (as captured with the I-RODS ${ }^{\odot}$ ) showed a significant correlation with grip strength as a linear objective measure in patients with GBS, CIDP, and MGUSP. No difference was seen between the right and left hand grip strength values related to the subjective measures completed by these patients. The use of grip strength in CIDP (and comparable conditions) has been questioned as an appropriate tool because it does not address lower limb function and therefore may be unreliable as a measure of treatment response. (17) Grip strength was therefore 
addressed being "imperfect" in daily practice in these conditions. (17) Our findings show a significant correlation between grip strength and I-RODS ${ }^{\odot}$, which also contains daily and social activities that are mobility driven, such as, walking one flight of stairs, travelling by public transportation, dancing, standing for hours, and ability to run. The correlation found, although not surprising to physicians treating patients with GBS, CIDP, and MGUSP, also indicates that the functional limitations have a more general impact, extending to the upper limbs as well.

Grip strength has been shown to be a sensitive tool to detect clinically relevant improvement or deterioration, sometimes with greater sensitivity than other commonly used generic disability measures. (14) Its scientific requirements in inflammatory neuropathies have been thoroughly demonstrated. (14-16, 24) In other conditions, grip strength is considered a good prognostic indicator of functional recovery. $(25,26)$ This easily applicable tool provides much greater objective information regarding a patient's general functioning and well-being, despite only measuring distal upper limb strength, and explains in CIDP and MGUSP up to $1 / 3$ of functional deficit in these conditions and half of the daily/ social activities encountered by patients with GBS are being explained by grip strength values (see Figure). In addition, the I-RODS ${ }^{\odot}$ is the only interval measure to assess general functionality in patients with GBS, CIDP, and MGUSP and has fulfilled all modern Rasch-built scientific requirements. $(11,13,27)$ Its superiority over generally applied often ordinal-based impairment and disability measures has recently been demonstrated, as well as showing some cross-cultural validity. $(13,28)$ Through a consensus meeting with international experts in the field of inflammatory neuropathies and patient's representative, it was concluded the I-RODS ${ }^{\odot}$ and the Vigorimeter being the most sensitive tools in these conditions. (12)

In future perspective for daily clinical practice, the I-RODS and grip strength could be used to help establish patients' 'baseline' performance and to evaluate the effects of treatments, like immunomodulatory therapy. Currently efforts are being undertaken to make the I-RODS more easily and widely accessible through a website and App construction, as well as embedding it into registries in inflammatory neuropathies.

(29) Our findings support, in addition to the literature findings, the routine use of the I-RODS ${ }^{\odot}$ and the grip strength in clinical trials and follow-up studies in patients with inflammatory neuropathies. 


\section{REFERENCES}

1. (USDHHS) UDoHaHS. Guidance for industry. Patient-Reported Outcome Measures: Use in Medical Product Development to Support Labeling Claims 2009. Available from: http:// www.fda.gov/downloads/Drugs/GuidanceComplianceRegulatory\%20Information/Guidances/ UCM193282.pdf.

2. Basch E. The missing voice of patients in drug-safety reporting. The New England journal of medicine. 2010;362(10):865-9.

3. Willke RJ, Burke LB, Erickson P. Measuring treatment impact: a review of patient-reported outcomes and other efficacy endpoints in approved product labels. Controlled clinical trials. 2004;25(6):535-52.

4. Puhan MA, Soesilo I, Guyatt GH, Schunemann HJ. Combining scores from different patient reported outcome measures in meta-analyses: when is it justified? Health and quality of life outcomes. 2006;4:94.

5. Lasch KE, Marquis P, Vigneux M, Abetz L, Arnould B, Bayliss M, et al. PRO development: rigorous qualitative research as the crucial foundation. Quality of life research : an international journal of quality of life aspects of treatment, care and rehabilitation. 2010;19(8):1087-96.

6. Magasi S, Ryan G, Revicki D, Lenderking W, Hays RD, Brod M, et al. Content validity of patientreported outcome measures: perspectives from a PROMIS meeting. Quality of life research : an international journal of quality of life aspects of treatment, care and rehabilitation. 2012;21(5):73946.

7. Trujols J, Portella MJ, Iraurgi I, Campins MJ, Sinol N, de Los Cobos JP. Patient-reported outcome measures: are they patient-generated, patient-centred or patient-valued? Journal of mental health. 2013;22(6):555-62.

8. McKenna SP. Measuring patient-reported outcomes: moving beyond misplaced common sense to hard science. BMC medicine. 2011;9:86.

9. Patrick DL, Burke LB, Powers JH, Scott JA, Rock EP, Dawisha S, et al. Patient-reported outcomes to support medical product labeling claims: FDA perspective. Value in health : the journal of the International Society for Pharmacoeconomics and Outcomes Research. 2007;10 Suppl 2:S12537.

10. Calvert M, Kyte D, Duffy H, Gheorghe A, Mercieca-Bebber R, Ives J, et al. Patient-reported outcome (PRO) assessment in clinical trials: a systematic review of guidance for trial protocol writers. PloS one. 2014;9(10):e110216.

11. van Nes SI, Vanhoutte EK, van Doorn PA, Hermans M, Bakkers M, Kuitwaard K, et al. Raschbuilt Overall Disability Scale (R-ODS) for immune-mediated peripheral neuropathies. Neurology. 2011;76(4):337-45.

12. Vanhoutte EK, Faber CG, Merkies IS. 196th ENMC international workshop: Outcome measures in inflammatory peripheral neuropathies 8-10 February 2013, Naarden, The Netherlands. Neuromuscul Disord. 2013;23(11):924-33. 
13. Draak TH, Vanhoutte EK, van Nes SI, Gorson KC, Van der Pol WL, Notermans NC, et al. Changing outcome in inflammatory neuropathies: Rasch-comparative responsiveness. Neurology. 2014;83(23):2124-32.

14. Vanhoutte EK, Latov N, Deng C, Hanna K, Hughes RA, Bril V, et al. Vigorimeter grip strength in CIDP: a responsive tool that rapidly measures the effect of IVIG--the ICE study. European journal of neurology. 2013;20(5):748-55.

15. Merkies IS, Schmitz PI, Samijn JP, Meche FG, Toyka KV, van Doorn PA. Assessing grip strength in healthy individuals and patients with immune-mediated polyneuropathies. Muscle $\&$ nerve. 2000;23(9):1393-401.

16. Hughes RA, Donofrio P, Bril V, Dalakas MC, Deng C, Hanna K, et al. Intravenous immune globulin ( $10 \%$ caprylate-chromatography purified) for the treatment of chronic inflammatory demyelinating polyradiculoneuropathy (ICE study): a randomised placebo-controlled trial. The Lancet Neurology. 2008;7(2):136-44.

17. Dimberg EL. Grip strength in CIDP: does one function fit all? European journal of neurology. 2013;20(5):733-4.

18. EuroQol G. EuroQol--a new facility for the measurement of health-related quality of life. Health policy. 1990;16(3):199-208.

19. van Nes SI, Faber CG, Merkies IS. Outcome measures in immune-mediated neuropathies: the need to standardize their use and to understand the clinimetric essentials. Journal of the peripheral nervous system : JPNS. 2008;13(2):136-47.

20. Research criteria for diagnosis of chronic inflammatory demyelinating polyneuropathy (CIDP). Report from an Ad Hoc Subcommittee of the American Academy of Neurology AIDS Task Force. Neurology. 1991;41(5):617-8.

21. Asbury AK, Cornblath DR. Assessment of current diagnostic criteria for Guillain-Barre syndrome. Annals of neurology. 1990;27 Suppl:S21-4.

22. Miescher GC, Steck AJ. Paraproteinaemic neuropathies. Bailliere's clinical neurology. 1996;5(1):219-32.

23. Dwyer J FM, Lippert P, Hoffmeister H (Eds.). Statistical models for longitudinal studies of health. New York: Oxford University press; 1992. 385 p.

24. Leger JM, De Bleecker JL, Sommer C, Robberecht W, Saarela M, Kamienowski J, et al. Efficacy and safety of Privigen $((\mathrm{R}))$ in patients with chronic inflammatory demyelinating polyneuropathy: results of a prospective, single-arm, open-label Phase III study (the PRIMA study). Journal of the peripheral nervous system : JPNS. 2013;18(2):130-40.

25. Orndahl G, Sellden U, Hallin S, Wetterqvist H, Rindby A, Selin E. Myotonic dystrophy treated with selenium and vitamin E. Acta medica Scandinavica. 1986;219(4):407-14. 
26. Sunderland A, Tinson D, Bradley L, Hewer RL. Arm function after stroke. An evaluation of grip strength as a measure of recovery and a prognostic indicator. Journal of neurology, neurosurgery, and psychiatry. 1989;52(11):1267-72.

27. Tennant A, Conaghan PG. The Rasch measurement model in rheumatology: what is it and why use it? When should it be applied, and what should one look for in a Rasch paper? Arthritis Rheum. 2007;57(8):1358-62.

28. Vanhoutte EK, Draak TH, Gorson KC, van Nes SI, Hoeijmakers JG, Van der Pol WL, et al. Impairment measures versus inflammatory RODS in GBS and CIDP: a responsiveness comparison. Journal of the peripheral nervous system : JPNS. 2015;20(3):289-95.

29. van Doorn PA. Diagnosis, treatment and prognosis of Guillain-Barre syndrome (GBS). Presse medicale. 2013;42(6 Pt 2):e193-201. 
\begin{tabular}{l|l} 
Correlation subjective versus objective & 63
\end{tabular} 

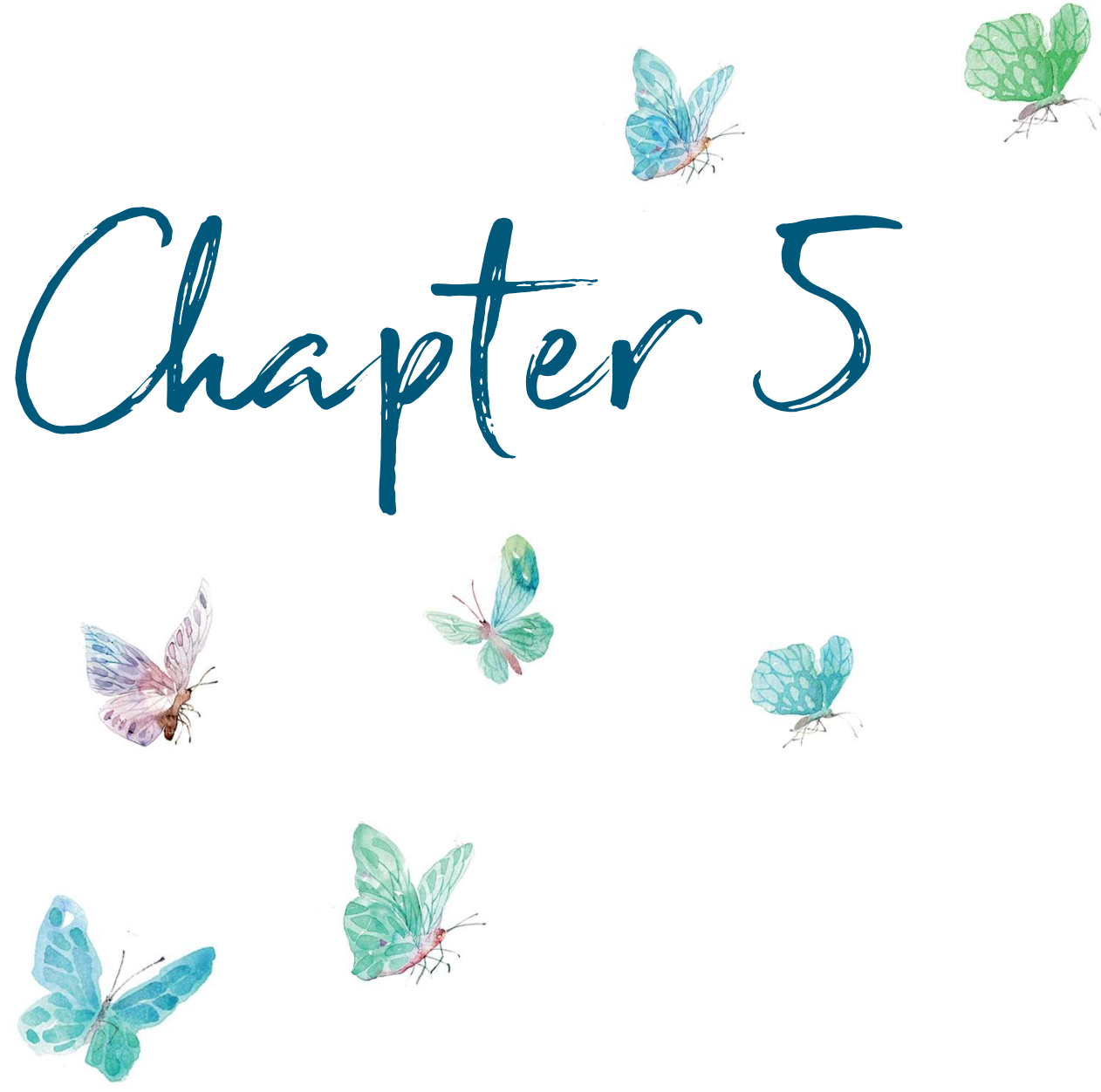


\section{Quality of life in inflammatory neuropathies: the IN-QoL}

Thomas H.P. Draak, Catharina G. Faber, Ingemar S.J. Merkies, on behalf of the PeriNomS study Group

Adapted from: J Neurol Neurosurg Psychiatry. 2018 Mar;89(3):256-262. 


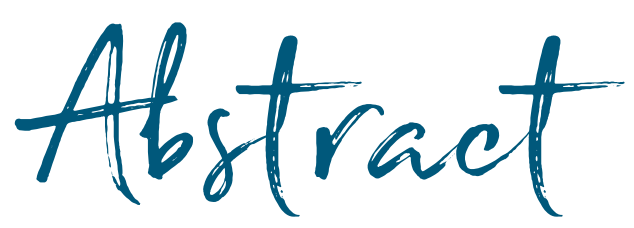

\section{BACKGROUND}

No consensus exists which quality of life (QoL) measure should be used in patients with inflammatory neuropathies. Moreover, most QoL measures are ordinal-based scales with their known deficiencies.

\section{OBJECTIVES}

To establish a new disease specific interval-based QoL-questionnaire in inflammatory neuropathies (IN-QoL) using the Rasch model and evaluate its scientific properties (validity, reliability, and responsiveness).

\section{METHODS}

264 patients with inflammatory neuropathies completed six commonly used QoLquestionnaires. The obtained data were stacked and subjected to Rasch analysis. Responsiveness was determined by using the concept of minimum clinically important differences related to varying individually obtained standard errors (responsiveness definition: MCID-SE $\geq 1.96$ after one year follow-up compared to baseline).

\section{RESULTS}

The IN-QoL fulfilled all Rasch's model requirements with high internal reliability values (patient separation index of 0.94), except being multidimensional. Additional factor analysis resulted in two (Functional and Mental) subsets that were unidimensional on their own. The IN-QoL showed good correlation with the EuroQol-health quality visual analogue scale (EQ-VAS) (Spearman's rho 0.72). It demonstrated acceptable responsiveness in patients with Guillain-Barré syndrome (GBS) and chronic inflammatory demyelinating polyradiculoneuropathy (CIDP), as did the EQ-VAS. In patients with gammopathy-related neuropathy (MGUSP) and multifocal motor neuropathy $(\mathrm{MMN})$, hardly any changes were seen over time.

\section{CONCLUSION}

The IN-QoL questionnaire fulfills modern clinimetric requirements and correlates strongly with a patient's self-assessment of their own quality of health, while also showing responsiveness in GBS and CIDP patients. We propose using the IN-QoL and the EQ-VAS for assessing the quality of life of patients with inflammatory neuropathies in future studies. 


\section{INTRODUCTION}

Quality of life (QoL) is a highly valued outcome measurement in any chronic illness in modern medicine. Over time, a multitude of questionnaires have been developed aiming to capture patient's QoL.(1-8) These questionnaires are created for example through patient focused groups, experts' opinion or by combining different pre-existing questionnaires. Several of these questionnaires have fulfilled the basic clinimetric requirements like being valid, reliable, and responsive.(4-8)

However, most, if not all, QoL instruments have limitations such as summing up ordinal data with their known deficiencies.(9-12) Furthermore, they are often used outside the field for which they were initially developed, assuming that QoL could be captured in the same way across all fields of medicine, thus not respecting potential disease-specific aspects. Only few scales are designed specifically for peripheral neuropathies, but both are based on ordinal sum scores. $(7,13)$ To date no consensus exists regarding which QoL measure should be used in patients with inflammatory neuropathies.

Based on these observations, we aimed to create an interval-based QoL-questionnaire specifically for inflammatory neuropathies (IN-QoL) from a comprehensive set of items, originating from six commonly used QoL-questionnaires, aiming for the metric to be unidimensional, free from item bias, without disordered thresholds or local dependency, and fulfilling all Rasch model requirements. In addition, we examined the scientific soundness (validity, reliability, and responsiveness) of the INQoL. In particular, we correlated the IN-QoL findings with patients' own ability to address their health quality using the EuroQol-health quality visual analogue scale (EQ-VAS).(3) We postulated that there would be a strong correlation between the outcome of the new questionnaire and patient's self-assessed quality of health.

\section{METHODS}

\section{Patients}

This study is part of the Peripheral Neuropathy Outcome Measures Standardization (PeriNomS) Study (duration: 7 years; database closed December 31, 2012), an international collaborative effort of 26 neuromuscular centers with special interest in inflammatory neuropathies, located in 9 countries (United States, Canada, Spain, Brazil, Italy, France, Belgium, the Netherlands, and United Kingdom). A total of 264 patients with Guillain-Barre syndrome (GBS), chronic inflammatory demyelinating polyradiculopathy (CIDP), IgM monoclonal gammopathy-related polyneuropathy (MGUSP) and multifocal motor neuropathy (MMN) were included in the study. 
These patients completed the WHO quality of life scale (WHOQoL BREF),(1) Sickness Impact Profile (SIP),(2) EuroQoL scale,(3) Nottingham Health Profile (NHP), (4) short form 36-item health survey (SF-36), (5, 6, 8) and Vickrey Peripheral Neuropathy Quality-of-Life Instrument-97 (PNQoL-97).(7) The questionnaires were made available using the validated native language versions (English, Spanish, Portuguese, Italian, French, German and Dutch). The obtained data from these questionnaires were stacked creating a large pre-IN-QoL pooled data-set.

Eligibility, standard protocol approvals, registrations, and patient consents Eligibility included normal cognitive function, age 18 years or older, fulfilling international criteria for the diagnosis of GBS, CIDP, IgM (preferably antiMAG+)-MGUSP or multifocal motor neuropathy (MMN) (14-17) having clinical deterioration as judged by the patient and physician, and not receiving immunetherapy for their polyneuropathy at least 2 months before inclusion.

Patients were excluded if other causes of polyneuropathy (e.g., renal insufficiency, diabetes mellitus) or any other conditions (e.g., alcohol abuse: $>5 \mathrm{IU} / \mathrm{d}$ ) that might interfere with nervous system and physical functioning (e.g., arthritis) were present. All patients gave written informed consent before participation in the study. The local medical ethics committee in each participating center approved the protocol.

\section{Procedures and statistics}

Rasch analysis 1: pre-IN-QoL

The records originating from the six QoL-questionnaires were stacked resulting in a total of 324 items in one dataset.

First, the data were subjected to a quality control, in which items with $>15 \%$ missing values and patients with $>15 \%$ unanswered items were omitted.

Second, the data was split up into 3 random groups. This was done to improve the item-to-patient ratio, as most measurement models require a higher total number of patients than total number of items, as is the case for the Rasch unidimensional measurement methods (RUMM2030) used. $(18,19)$

Third, the data in our randomly created three subgroups were checked for misfitting items (which was defined as either having a fit residuals exceeding \pm 2.5 or a significant $\chi^{2}$-probability (after Bonferroni adjustment)) and disordered thresholds (20) using RUMM2030 (Rasch Unidimensional Measurement Models 2030)(21), and, if found, these items were stepwise removed.

Fourth, the remaining items from all 3 subgroups were merged resulting in the socalled pre-IN-QoL. For an algorithm regarding this procedure, see Figure 1. For additional details regarding the statistical and mathematical background regarding these steps we refer the reader to the supplemental document. 


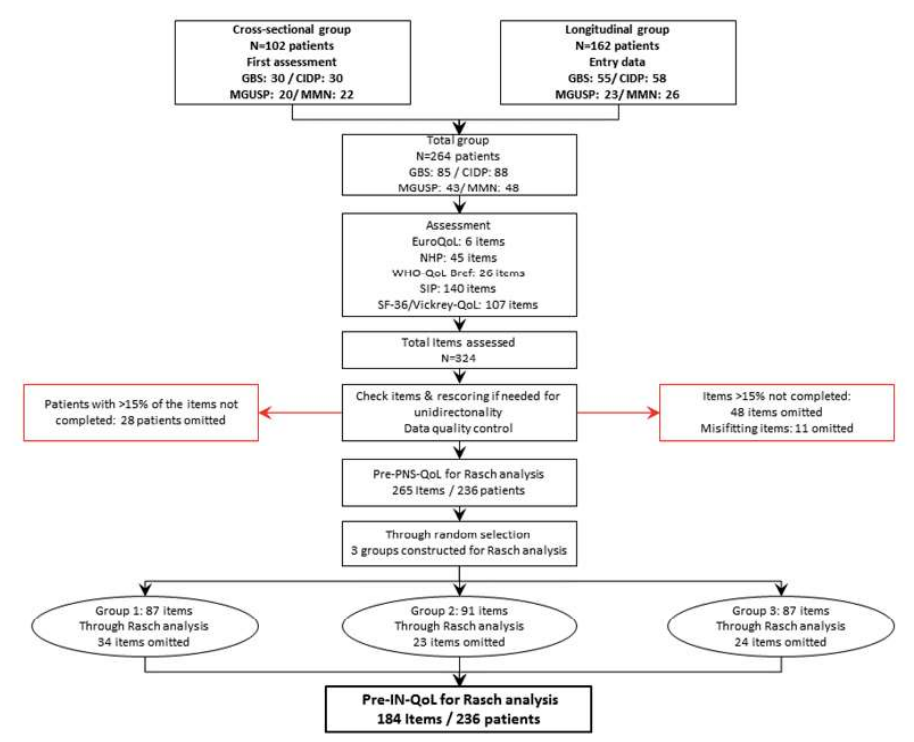

FIGURE 1: Algorithm for the development of the pre-IN-QoL.

CIDP,chronic inflammatory demyelinating polyradiculopathy; GBS, Guillain-Barré syndrome; IN-QoL, inflammatory neuropathies Quality of Life questionnaire; MGUSP, monoclonal gammopathy-related polyneuropathy; MMN, multifocal motor neuropathy; NHP, Nottingham Health Profile; SF-36, short form 36item health survey; SIP, Sickness Impact Profile.

\section{Rasch analysis 2: creating the final IN-QoL}

The pre-IN-QoL was subsequently analyzed through Rasch modeling. All item sets with correlations above 0.3 were evaluated starting with the highest correlations $(>0.7,>0.6, \ldots .$. up to $>0.3)$. Of each item set, the item with the most over- or under-discrimination on its category probability curve, eventually combined with less face validity, was removed. For item bias, we used the following person factors: age categories (18-50 years vs 51-63 years vs 64-90 years), gender (men vs women) and diagnosis type (GBS, CIDP, MGUSP and MMN). The age groups were created to obtain an optimal equal distribution in size between the groups. Misfitting persons were identified as showing fit residuals exceeding \pm 2.5 or a significant $\chi^{2}$ probability (after Bonferroni adjustment). We performed a binominal T-test to test for multidimensionality. QoL-questionnaires are generally known for either more physically or mentally oriented items. Therefore, if multidimensionality was found, a factor analysis was also performed using Stata 13.0. For an algorithm regarding this procedure, see Figure 2. For additional information and an example on uniform Differential Item Functioning (DIF), see Figure 3. 


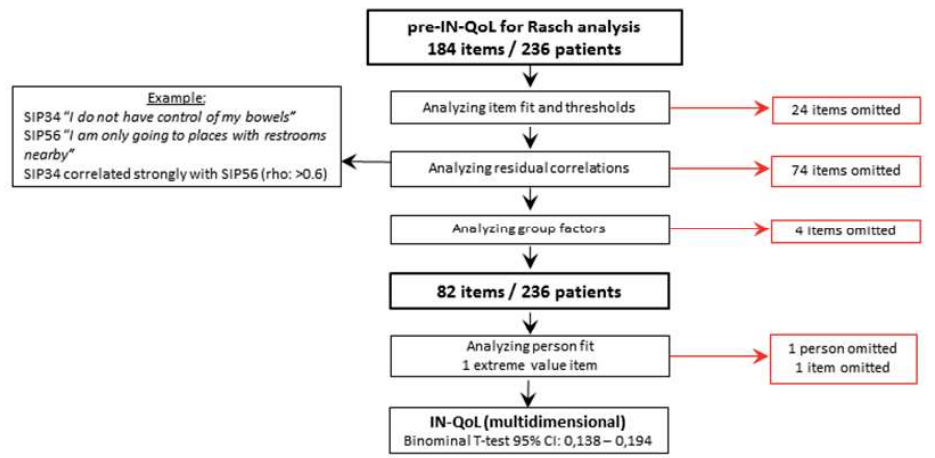

FIGURE 2: Algorithm for the development of the IN-QoL

IN-QoL: inflammatory neuropathies Quality of Life questionnaire; SIP: Sickness Impact Profile.

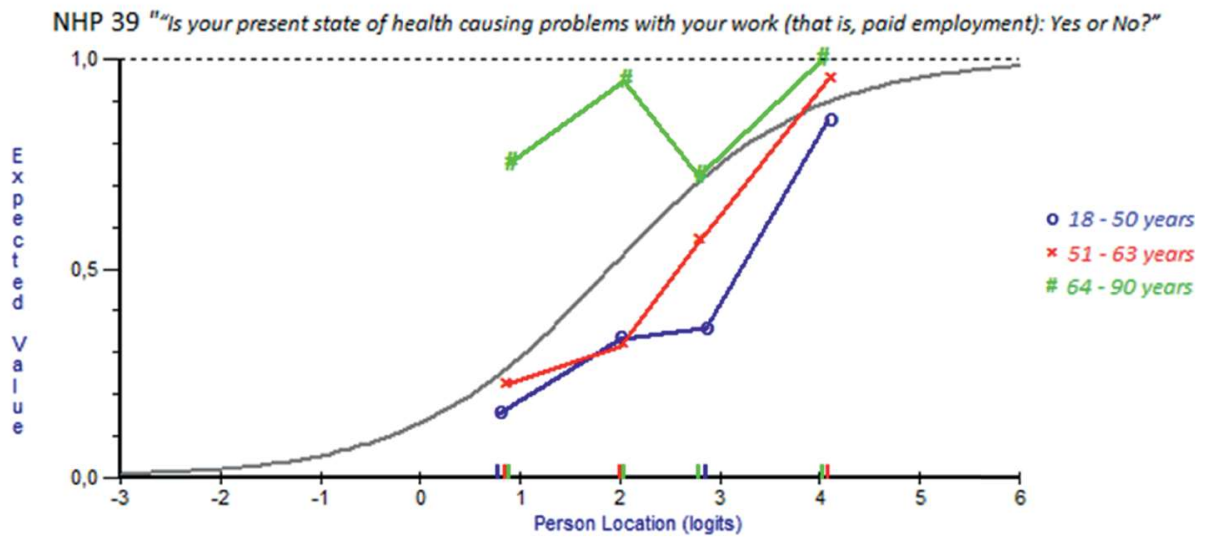

FIGURE 3: Example of uniform Differential Item Functioning (DIF).

In gray, the curve depicts the expected value based on a person's location. As can be seen, for age groups $18-$ 50 years and $51-63$ years there is a similar shaped curve. The curve for 64-90 years is clearly different showing no resemblance to the expected curve. This is an indication for uniform Differential Item Functioning (DIF).

As a final step, knowing that subjects generally are unable to differentiate between more than four response options $(22,23)$, and to establish more uniformity within the final scale, items with five Likert-type response options were rescored resulting in two or three response options for all items taking the distribution of the scores per response item into account.

\section{Validity, Reliability, and Responsiveness}

The correlation between the IN-QoL and the EQ-VAS was determined after transforming the IN-QoL to a centile metric scale ranging from 0 to 100 (Spearman's rho correlation test; validity study). The EQ-VAS ranges from 0 "worst imaginable 


$\mathrm{MCID}-\mathrm{SE}=\frac{\text { Personal change }}{\mathrm{SE}_{\text {diff }}}=\frac{\text { Position }_{12}-\text { Position }_{0}}{\sqrt{ }\left(\mathrm{SE}_{0}{ }^{2}+\mathrm{SE}_{12}{ }^{2}\right)}$
Subgroups
1 (clinically important improvement): MCID-SE $\geq 1.96 ;$
2 (clinically unimportant improvement): $0<\mathrm{MCID}-\mathrm{SE}<1.96 ;$
3 (no change): MCID-SE $=0$;
4 (clinically unimportant deterioration): $-1.96<\mathrm{MCID}-\mathrm{SE}<0 ;$
5 (clinically important deterioration): MCID-SE $\leq-1.96$

FIGURE 4: Formula and classification of the MCID-SE values.

health state" to 100 "best imaginable health state". To establish the internal reliability, the Person Separation Index (PSI) was determined. In general, a PSI above 0.7 is considered as acceptable, indicating the ability to identify at least 2 groups of patients. (24)

Patients completed all six QoL-questionnaires at entry and 1 year later, and the final IN-QoL was extracted from these data to determine its responsiveness.

To determine responsiveness of the IN-QoL, the individual standard errors (SE) were determined for each patient, alongside their locations on the logits-ruler. SEs may vary across the theoretical range of an outcome measure, and therefore the significance of a clinically meaningful change in any particular patient may also vary. (25) The minimal clinically important difference (MCID)-related SE (MCID-SE) score is based on the previously described significant changes. The MCID-SE was calculated for each patient separately. See Figure 4 for the formula and classification of the MCID-SE values.

The responsiveness of the EQ-VAS was determined in a similar fashion. As there is no personal $S E$ attainable for a single value, the group SE for each visit was calculated by Stata 13.0 and was used to determine the MCID-SE for the EQ-VAS.

\section{Software}

Rasch analyses were performed with the partial credit model as default, using RUMM2030 software. (21) Further analyses were undertaken using Stata 13.0 for Windows XP. 


\section{RESULTS}

\section{Patients}

The basic characteristics of the patients in our initial dataset are presented in Table 1A, for our final IN-QoL questionnaire in Table $1 \mathrm{~B}$ and the patients used to determine responsiveness from our longitudinal dataset are presented in Table 1C.

TABLE 1A. Basic characteristics of patients in initial dataset before any omissions.

\begin{tabular}{llllll}
\hline & GBS & CIDP & MGUSP & MMN & Total \\
\hline $\begin{array}{lllll}\text { Age groups } \\
\text { - 18-50 }\end{array}$ & & & & & \\
- $51-63$ & 27 & 30 & 5 & 25 & $87(33 \%)$ \\
- 64 and older & 30 & 34 & 12 & 11 & $87(33 \%)$ \\
Gender & 28 & 24 & 26 & 12 & $90(34 \%)$ \\
- Female & & & & & \\
- Male & 35 & 25 & 11 & 10 & $81(31 \%)$ \\
\hline Total & 50 & 63 & 32 & 38 & $183(69 \%)$ \\
\hline
\end{tabular}

TABLE 1B. Basic characteristics of patients used in final IN-QoL questionnaire.

\begin{tabular}{llllll}
\hline & GBS & CIDP & MGUSP & MMN & Total \\
\hline $\begin{array}{l}\text { Age groups } \\
\text { - } 18-50\end{array}$ & 21 & 25 & 4 & 23 & $73(31 \%)$ \\
- $51-63$ & 24 & 34 & 15 & 13 & $86(37 \%)$ \\
- 64 and older & 23 & 20 & 22 & 11 & $76(32 \%)$ \\
$\begin{array}{l}\text { Gender } \\
\text { - Female }\end{array}$ & & & & & \\
- Male & 30 & 22 & 10 & 10 & $72(31 \%)$ \\
\hline Total & 38 & 57 & 31 & 37 & $163(69 \%)$ \\
\hline
\end{tabular}

TABLE 1C. Basic characteristics of patients from longitudinal dataset to determine responsiveness

\begin{tabular}{llllll}
\hline & GBS & CIDP & MGUSP & MMN & Total \\
\hline $\begin{array}{llll}\text { Age groups } \\
\text { - 18-50 }\end{array}$ & 13 & 12 & 2 & 8 & $35(35 \%)$ \\
- $51-63$ & 9 & 16 & 6 & 4 & $35(35 \%)$ \\
- 64 and older & 7 & 11 & 9 & 4 & $31(31 \%)$ \\
$\begin{array}{l}\text { Gender } \\
\text { - Female }\end{array}$ & 10 & 11 & 6 & 4 & $31(31 \%)$ \\
- Male & 19 & 28 & 11 & 12 & $70(69 \%)$ \\
\hline Total & $29(29 \%)$ & $39(39 \%)$ & $17(17 \%)$ & $16(16 \%)$ & $101(100 \%)$ \\
\hline
\end{tabular}

Percentages are related to the total population and are rounded off. GBS: Guillain-Barré syndrome; CIDP: chronic inflammatory demyelinating polyradiculoneuropathy; MGUSP: monoclonal gammopathy of undetermined significant related polyneuropathy; $\mathrm{MMN}$ : multifocal motor neuropathy 


\section{Procedures and statistics}

\section{Rasch analysis 1: creating the pre-IN-QoL}

A total of $n=264$ patients and $n=324$ were initially collected. After data quality control, 28 patients and 59 items were omitted from the initial dataset, leaving 236 patients and 265 items (Figure 1). Additionally, 81 items were omitted from the 3 randomly selected subgroups based on misfit statistics and/or exceeding fit residual, hence improving the patients-to-items ratio. The remaining items from these 3 subgroups were joined, resulting in the pre-IN-QoL consisting out of 184 items, see Figure 1.

\section{Rasch analysis 2: creating the IN-QoL}

The pre-IN-QoL ( $\mathrm{n}=236$ patients/n=184 items; see Figure 2) mean items' fit residual showed a decent model fit (mean -0.287, SD 1.169) and persons' fit residual (mean -0.284, SD 1.180). However, the mean person location was 2.061 (SD 1.218), deviating substantially from the model's aimed mean value around 0 . The itemtrait interaction (an indication of the consistency of the item difficulties across the scale) showed a $\mathbb{Q}^{2}$ probability of $<0.05$, indicating misfit to the Rasch model and potentially measuring non-unidimensional traits.

A total of 24 items with misfit statistics were stepwise omitted ( $\mathrm{n}=160$ items remaining). Also, $\mathrm{n}=74$ items' residual correlations showing local dependency were stepwise removed ( $\mathrm{n}=86$ items remaining). An example of a residual correlation is shown in Figure 2. Next, potential bias by group factors (age categories, gender and diagnosis type) was analysed, revealing 4 items with bias (2 having uniform differential item function (U-DIF) and 1 showing non-uniform DIF (NU-DIF) on age-categories, and 1 item having NU-DIF on diagnosis. An example can also be found in Figure 3.

Finally, person fit and item fit were analysed, resulting in the omission of 1 item (extreme value, ceiling effect) and 1 person (extreme value, $>2.5$ fit residual). The final questionnaire IN-QoL consisted of 81 items in 235 subjects.

A binominal paired-T-test showed a proportion of 0.17 of the paired-T- test performed falling outside the \pm 1.96 range with a $95 \%$ confidence interval (CI) of $0.138-0.194$ (indicating multidimensionality).

Additionally, exploratory factor analysis (EFA) was undertaken. With a sample of over 200 patients (as seen in this study), a scree plot provides a fairly reliable criterion for factor selection.(26) This EFA showed 2 underlying factors, in which the loading was deemed significant if it exceeded 0.3.(26) These factors were named 'Mental' and 'Functional'. Items not loading significantly were classified on their face and 


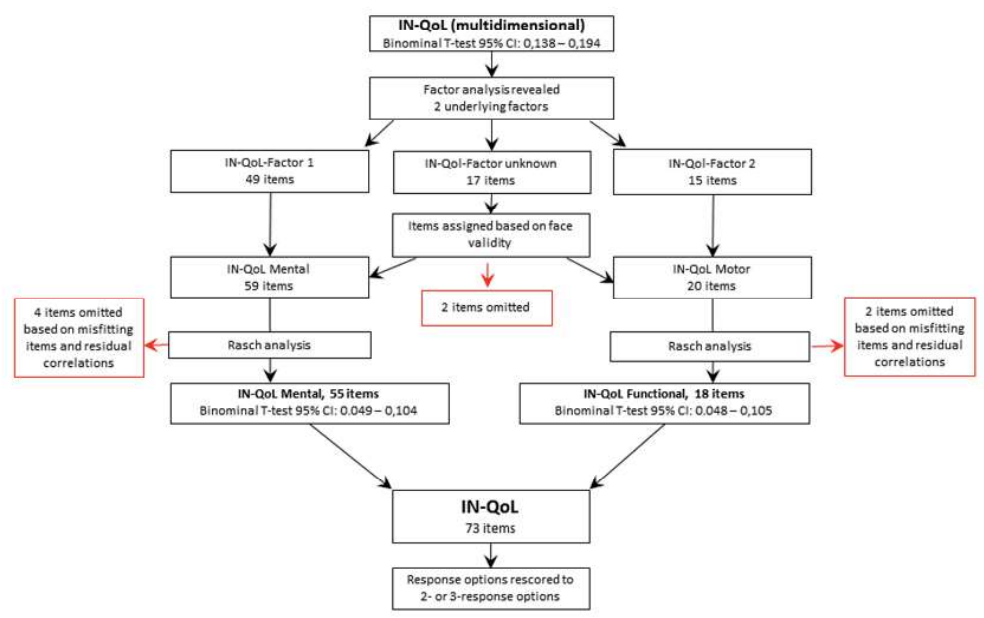

FIGURE 5: Algorithm for the factor analysis and subsequent steps for the development of the final IN-QoL. IN-QoL: inflammatory neuropathies Quality of Life questionnaire.

content validity between Mental and Functional after getting consensus between three experts (TD/CGF/ISJM). Two items that had both domains incorporated within their questions were omitted.

This resulted in two subset-questionnaires: a mental subset consisting of 59 items and a functional subset consisting of 20 items. These two subsets of items were again subjected to the above-mentioned rigorous Rasch analysis steps, which led to the omission of four items in the 'Mental' subset and two items in the 'Functional subset, based on misfitting items and significant residual correlations. Both final two remaining subsets showed a proportion of 0.08 of the paired-T- test performed falling outside the \pm 1.96 range, but with CIs for Mental being $0.049-0,104$ and Functional being $0.048-0,105$, indicating acceptable unidimensionality. The algorithm regarding this procedure is depicted in Figure 5.

The final IN-QoL consists of 73 items, with $n=55$ items as part of the 'Mental' subset and $\mathrm{n}=18$ items forming the 'Functional' subset (Appendix A). For the item-person distribution of the IN-QoL, see Figure 6.

\section{Validity, Reliability, and Responsiveness}

Both the IN-QoL and the Mental subset showed good correlation with EQ-VAS (Spearman's rho 0.72 and 0.71 , respectively with corresponding p-values $<0.0001$, Figure 7). The Functional subset showed a low, but significant correlation with EQVAS, having a Spearman's rho of 0.28 and corresponding p-value $<0.0001$. 


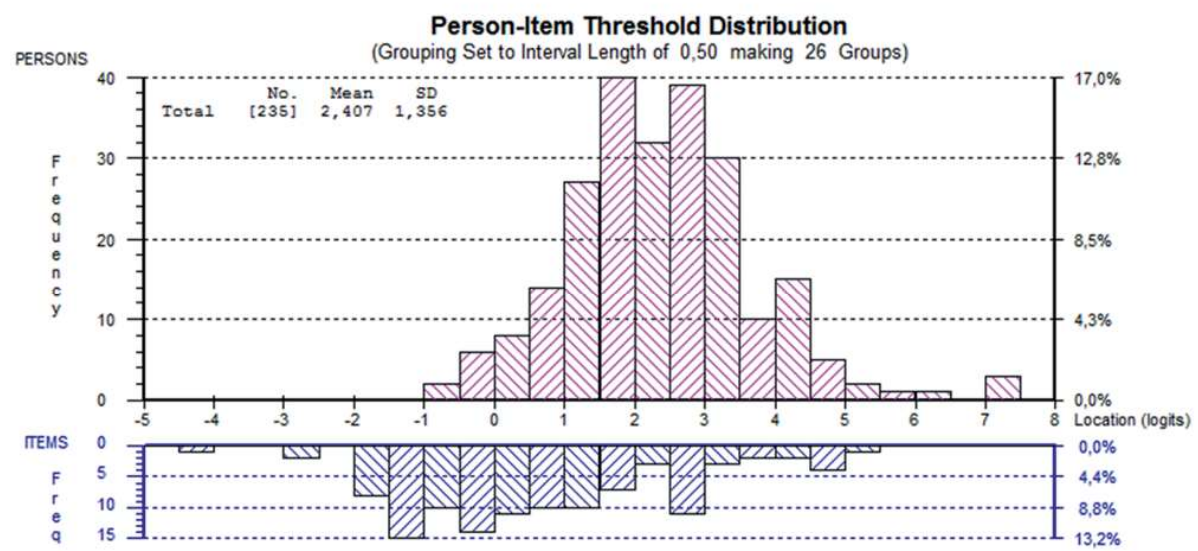

FIGURE 6: item-person distribution of the IN-QoL

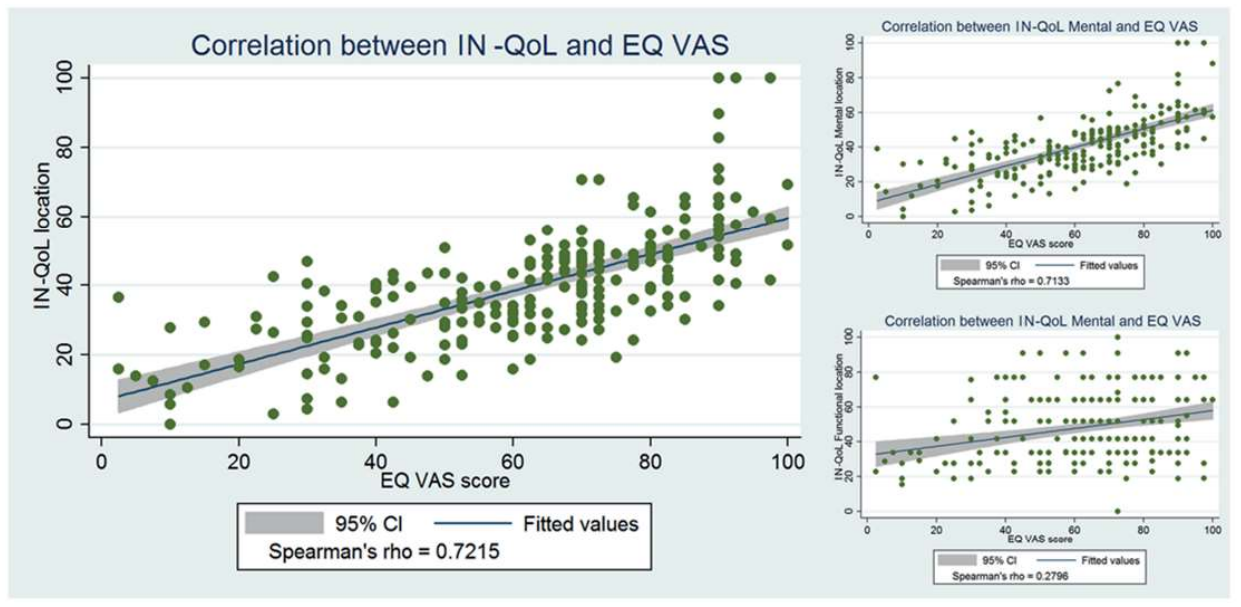

FIGURE 7: Correlation between IN-QoL (and subsets) and the EQ-VAS.

The text block also shows the corresponding Spearman's rho. EQ-VAS, EuroQol-health quality visual analogue scale; IN-QoL, inflammatory neuropathies Quality of Life questionnaire.

The questionnaire showed very good internal reliability (PSI 0.94). The subsets, the IN-QoL Mental and Functional, had a PSI of 0.93 and 0.73 , respectively.

Responsiveness was determined by calculating the MCID-SE (see Figure 8) for the IN-QoL, its subsets and the EQ-VAS. Next, we grouped the MCID-SE per illness, as due to the nature of the illnesses, differences in clinical change between them were expected. As can be seen in Figure 8, the EQ-VAS and the IN-QoL showed higher responsiveness in GBS and to some extent in CIDP, while MGUSP and MMN did 

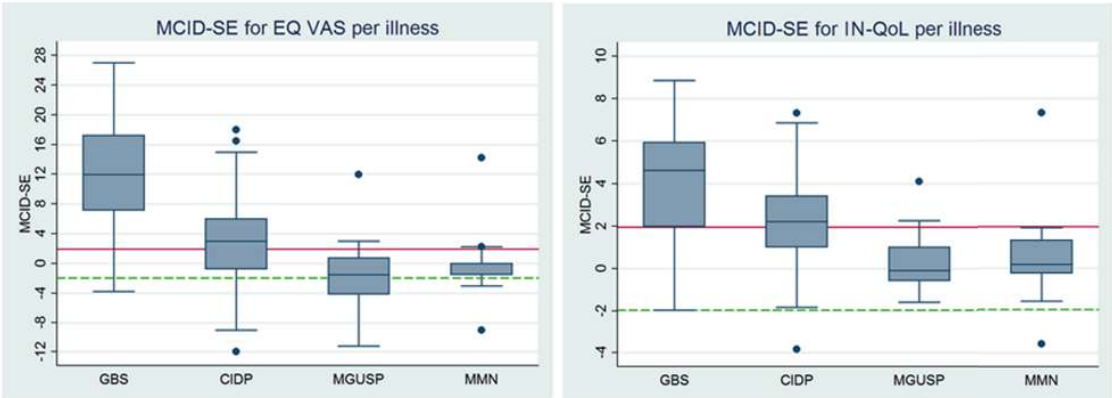

MCID-SE for IN-QOL Functional per illness
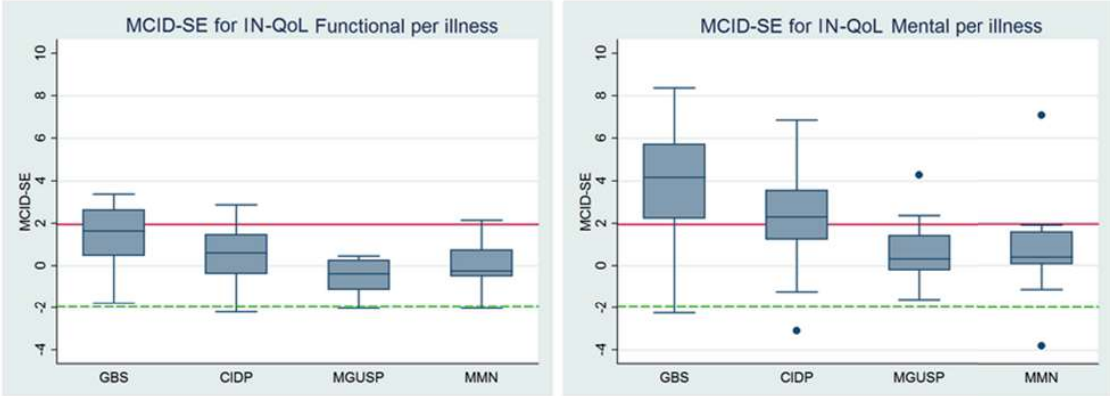

FIGURE 8: The MCID-SE for each instrument grouped by illness.

A reference line (solid, red) was added at $1.96 \mathrm{MCID}-\mathrm{SE}$, which is used as a cut-off for clinically important improvement. Also, a reference line (dash, green) was added at $-1.96 \mathrm{MCID}-\mathrm{SE}$, which is used as a cut-off for clinically important deterioration. Please note different scaling for the MCID-SE for EQ-VAS (left- top graphic). EQ-VAS, EuroQol-health quality visual analogue scale; MCID-SE, minimum clinically important differences related to varying individually obtained SE. IN-QoL, inflammatory neuropathies Quality of Life questionnaire

not show clinically important improvement. The IN-QoL Mental subset showed near similar responsiveness as the whole IN-QoL scale, while the IN-QoL Functional showed minimal clinically important change.

When looking at the EQ-VAS and the IN-QoL Functional, MGUSP and MMN patients tend to show a stable but clinically unimportant deterioration.

\section{DISCUSSION}

We were able to develop the IN-QoL for patients with inflammatory neuropathies (GBS, CIDP, MGUSP and MMN), through a stepwise rigorous methodological approach based on a dataset that emerged from six generally applied QoL measures, collected in a large patient population, and subjected to Rasch analysis. As expected, this new quality of life questionnaire, the IN-QoL, showed multidimensionality. After exploratory factor analysis, 2 underlying factors were detected, leading to two subsets, the so-called IN-QoL Mental and IN-QoL Functional subsets. These subsets 
fulfilled all Rasch model requirements of being free of item misfit and bias, without disordered thresholds or local dependency, and showing good internal reliability. The items in the IN-QoL show no bias with regard to the group factor 'diagnosis type' meaning that each item functions the same for each illness independently. The INQoL is the only Qol measure for inflammatory neuropathies with an interval level of data analysis.

The IN-QoL and its Mental subset showed a strong correlation with the EQ-VAS, which is a measurement in which the patient's own voice is reflected, providing information on their health quality status, thus showing acceptable correlation between a subjective and objective outcome measure, which is becoming more and more important.(27-30) The lack of correlation of the Functional subset with the EQ-VAS could be due to the fact patients rating their 'health quality' mostly based on their Mental impact and insecurity rather than their 'Functional' health.(31) Also for example in GBS and CIDP patients, functional recovery doesn't necessarily imply a good health quality due to residual complaints like fatigue, pain, depression, etc which is a known common complaint in these patients.(31-34)

Responsiveness of the IN-QoL and its Mental subset was demonstrated through a modern approach to determine a responder by using the MCID-SE method. With this method, the EQ-VAS showed responsiveness as well, however, determining responsiveness of VAS scores through the MCID-SE method may lead to under- or overestimating true change.(35) Although the pain VAS, which was examined in this study, met the requirements of the Rasch model, it's behavior wasn't linear as one would expect from interval data. In a recent review, they discuss the literature and conclude that the VAS score is in fact not an interval or ratio score, but behaves like an ordinal score.(36) We have studied the values of the EQ-VAS in our study population, and it did show some disordered thresholds and a tendency to nonlinearity, albeit far less than the pain VAS in the article by Kersten $e t$ al. Therefore, our findings regarding the EQ-VAS responsiveness should be interpreted with some caution, as it might be an overestimation.

Regarding responsiveness, it was to be expected that the GBS patients (and the CIDP patient to a lesser extent) would show the most responsiveness, due to a more dynamic course of the disease, as was also previously seen at other levels of assessing outcome in these disorders. $(37,38)$ The lack of responsiveness in MGUSP and MMN patients may be caused by the indolent nature of the illness, the relative short follow-up period of 1 year and/or less impact of treatment medication, although most patients with MGUSP did not receive any treatment, thus expecting a stable or nonimproved clinical picture. (39) One may argue how responsiveness in each illness 
should be defined. The concept of being responder should be part of a consensus meeting among experts in the field of inflammatory neuropathies alongside patient's representatives. (40) Aspects like the clinical dynamics (fast vs slow, acute vs chronic) and direction of changes, as well as the desire which type of trial to be conducted (improvement or maintenance) are just some pivotal aspects that should be taken into consideration when defining a responder taking into account its clinical relevance.

Our study and the new scale have some limitations. The new scale has not yet been tested prospectively in a larger population with inflammatory neuropathies, and responsiveness has been determined in a relatively small patient population. Currently a follow-up study (PeriNomS II) is being designed in which we can assess our scale prospectively. Our scale's cross-cultural validity needs to be investigated as well, which is essential for a questionnaire to be used in international trials. $(39,41,42)$ Nevertheless, we believe that the development of this disease-specific, interval-based quality of life questionnaire is a first major step in measuring such an important aspect from a patient's point of view, while not neglecting the proper clinimetric necessities.

Furthermore, we have shown that our patients are quite well capable of assessing their own quality of health by simply asking them to rate it in a direct question (the EQ-VAS). The use of endless lists filled with questions to establish their quality of life could be seen as a roundabout way to a very important aspect of a patient's life, compared to letting patient's themselves tell us their quality of health.

For future studies in inflammatory neuropathies, we suggest to use the IN-QoL as well as the EQ-VAS. Despite the limitations of over- or underestimating the EQ-VAS responsiveness by using the MCID-SE method as discussed above, we still believe it is important to have an outcome measure in which a patient can rate their own health and to help correlate our scale in future studies with the patient's own voice regarding their quality of life. We would however advise to transform the EQ-VAS to an interval scale before determining its responsiveness in future studies.

By using these two outcome measures, we will be using the best, interval-based, quality of life questionnaire for inflammatory neuropathies available so far, and this will also provide the opportunity to correlate the IN-QoL measure with the patient's own quality of health assessment in a prospective study. Eventually, if there still remains a strong correlation, we might be able to forgo long questionnaires for assessing quality of life in future studies all together, and simply ask the patient how they rate their own quality of life. 


\section{REFERENCES}

1. Development of the World Health Organization WHOQOL-BREF quality of life assessment. The WHOQOL Group. Psychological medicine. 1998;28(3):551-8.

2. Bergner M, Bobbitt RA, Carter WB, Gilson BS. The Sickness Impact Profile: development and final revision of a health status measure. Medical care. 1981;19(8):787-805.

3. EuroQol G. EuroQol--a new facility for the measurement of health-related quality of life. Health policy. 1990;16(3):199-208.

4. Hunt SM, McKenna SP, McEwen J, Backett EM, Williams J, Papp E. A quantitative approach to perceived health status: a validation study. Journal of epidemiology and community health. $1980 ; 34(4): 281-6$.

5. McHorney CA, Ware JE, Jr., Lu JF, Sherbourne CD. The MOS 36-item Short-Form Health Survey (SF-36): III. Tests of data quality, scaling assumptions, and reliability across diverse patient groups. Medical care. 1994;32(1):40-66.

6. McHorney CA, Ware JE, Jr., Raczek AE. The MOS 36-Item Short-Form Health Survey (SF-36): II. Psychometric and clinical tests of validity in measuring physical and mental health constructs. Medical care. 1993;31(3):247-63.

7. Vickrey BG, Hays RD, Beckstrand M. Development of a health-related quality of life measure for peripheral neuropathy. Neurorehabilitation and neural repair. 2000;14(2):93-104.

8. Ware JE, Jr., Sherbourne CD. The MOS 36-item short-form health survey (SF-36). I. Conceptual framework and item selection. Medical care. 1992;30(6):473-83.

9. Merbitz C, Morris J, Grip JC. Ordinal scales and foundations of misinference. Archives of physical medicine and rehabilitation. 1989;70(4):308-12.

10. Wright $\mathrm{BD}$, Linacre JM. Observations are always ordinal; measurements, however, must be interval. Arch Phys Med Rehabil. 1989;70(12):857-60.

11. Stucki G, Daltroy L, Katz JN, Johannesson M, Liang MH. Interpretation of change scores in ordinal clinical scales and health status measures: the whole may not equal the sum of the parts. J Clin Epidemiol. 1996;49(7):711-7.

12. Grimby G, Tennant A, Tesio L. The use of raw scores from ordinal scales: time to end malpractice? Journal of rehabilitation medicine. 2012;44(2):97-8.

13. Vileikyte L, Peyrot M, Bundy C, Rubin RR, Leventhal H, Mora P, et al. The development and validation of a neuropathy- and foot ulcer-specific quality of life instrument. Diabetes care. 2003;26(9):2549-55.

14. Joint Task Force of the E, the PNS. European Federation of Neurological Societies/Peripheral Nerve Society Guideline on management of chronic inflammatory demyelinating polyradiculoneuropathy: report of a joint task force of the European Federation of Neurological Societies and the Peripheral Nerve Society--First Revision. Journal of the peripheral nervous system : JPNS. 2010;15(1):1-9. 
15. Joint Task Force of the E, the PNS. European Federation of Neurological Societies/Peripheral Nerve Society Guideline on management of paraproteinemic demyelinating neuropathies. Report of a Joint Task Force of the European Federation of Neurological Societies and the Peripheral Nerve Society--first revision. Journal of the peripheral nervous system : JPNS. 2010;15(3):185-95.

16. Van der Meche FG, Van Doorn PA, Meulstee J, Jennekens FG, Centre GB-cgotDNRS. Diagnostic and classification criteria for the Guillain-Barre syndrome. European neurology. 2001;45(3):1339 .

17. European Federation of Neurological S, Peripheral Nerve S, van Schaik IN, Bouche P, Illa I, Leger JM, et al. European Federation of Neurological Societies/Peripheral Nerve Society guideline on management of multifocal motor neuropathy. European journal of neurology. 2006;13(8):802-8.

18. Tennant A, McKenna SP, Hagell P. Application of Rasch analysis in the development and application of quality of life instruments. Value Health. 2004;7 Suppl 1:S22-6.

19. Pallant JF, Tennant A. An introduction to the Rasch measurement model: an example using the Hospital Anxiety and Depression Scale (HADS). Br J Clin Psychol. 2007;46(Pt 1):1-18.

20. Tennant A, Conaghan PG. The Rasch measurement model in rheumatology: what is it and why use it? When should it be applied, and what should one look for in a Rasch paper? Arthritis Rheum. 2007;57(8):1358-62.

21. Andrich D SB, Luo G. . Rumm 2030: Rasch Unidimensional Measurement Models (software). 2012.

22. Andrich D. Category ordering and their utility. Rasch Meas Transact. 1996;9:464-65.

23. Penta M, Tesio L, Arnould C, Zancan A, Thonnard JL. The ABILHAND questionnaire as a measure of manual ability in chronic stroke patients: Rasch-based validation and relationship to upper limb impairment. Stroke. 2001;32(7):1627-34.

24. Fisher W. Reliability statistics. Rasch Measure Trans 1992;6:238.

25. Hobart J, Cano S. Improving the evaluation of therapeutic interventions in multiple sclerosis: the role of new psychometric methods. Health Technol Assess. 2009;13(12):iii, ix-x, 1-177.

26. Stevens JP. Applied Multivariate Statistics for the Social Sciences. 4th Edition2002.

27. Rabel C, Le Goff F, Lefaucheur R, Ozel G, Fetter D, Rouille A, et al. Subjective Perceived Motor Improvement after Acute Levodopa Challenge in Parkinson's Disease. Journal of Parkinson's disease. 2016;6(4):779-85.

28. Mills KA, Mari Z, Pontone GM, Pantelyat A, Zhang A, Yoritomo N, et al. Cognitive impairment in Parkinson's disease: Association between patient-reported and clinically measured outcomes. Parkinsonism \& related disorders. 2016.

29. Hwang DY, Dell CA, Sparks MJ, Watson TD, Langefeld CD, Comeau ME, et al. Clinician judgment vs formal scales for predicting intracerebral hemorrhage outcomes. Neurology. 2016;86(2):126-33. 
30. Draak TH, Gorson KC, Vanhoutte EK, van Nes SI, van Doorn PA, Cornblath DR, et al. Correlation of the patient's reported outcome Inflammatory-RODS with an objective metric in immune-mediated neuropathies. European journal of neurology. 2016;23(7):1248-53.

31. Bernsen RA, de Jager AE, Kuijer W, van der Meche FG, Suurmeijer TP. Psychosocial dysfunction in the first year after Guillain-Barre syndrome. Muscle \& nerve. 2010;41(4):533-9.

32. Merkies IS, Schmitz PI, Samijn JP, van der Meche FG, van Doorn PA. Fatigue in immunemediated polyneuropathies. European Inflammatory Neuropathy Cause and Treatment (INCAT) Group. Neurology. 1999;53(8):1648-54.

33. Merkies IS, Kieseier BC. Fatigue, Pain, Anxiety and Depression in Guillain-Barre Syndrome and Chronic Inflammatory Demyelinating Polyradiculoneuropathy. European neurology. 2016;75(34):199-206.

34. Ruts L, Drenthen J, Jongen JL, Hop WC, Visser GH, Jacobs BC, et al. Pain in Guillain-Barre syndrome: a long-term follow-up study. Neurology. 2010;75(16):1439-47.

35. Kersten P, White PJ, Tennant A. Is the pain visual analogue scale linear and responsive to change? An exploration using Rasch analysis. PLoS One. 2014;9(6):e99485.

36. Kersten P, Kucukdeveci AA, Tennant A. The use of the Visual Analogue Scale (VAS) in rehabilitation outcomes. Journal of rehabilitation medicine. 2012;44(7):609-10.

37. Draak TH, Vanhoutte EK, van Nes SI, Gorson KC, Van der Pol WL, Notermans NC, et al. Changing outcome in inflammatory neuropathies: Rasch-comparative responsiveness. Neurology. 2014;83(23):2124-32.

38. Vanhoutte EK, Draak TH, Gorson KC, van Nes SI, Hoeijmakers JG, Van der Pol WL, et al. Impairment measures versus inflammatory RODS in GBS and CIDP: a responsiveness comparison. Journal of the peripheral nervous system : JPNS. 2015;20(3):289-95.

39. Pruppers MH, Merkies IS, Notermans NC. Recent advances in outcome measures in IgM-antiMAG+ neuropathies. Current opinion in neurology. 2015;28(5):486-93.

40. Vanhoutte EK, Faber CG, Merkies IS, PeriNom Ssg. 196th ENMC international workshop: Outcome measures in inflammatory peripheral neuropathies 8-10 February 2013, Naarden, The Netherlands. Neuromuscular disorders : NMD. 2013;23(11):924-33.

41. Guillemin F, Bombardier C, Beaton D. Cross-cultural adaptation of health-related quality of life measures: literature review and proposed guidelines. Journal of clinical epidemiology. 1993;46(12):1417-32.

42. Kucukdeveci AA, Sahin H, Ataman S, Griffiths B, Tennant A. Issues in cross-cultural validity: example from the adaptation, reliability, and validity testing of a Turkish version of the Stanford Health Assessment Questionnaire. Arthritis and rheumatism. 2004;51(1):14-9. 


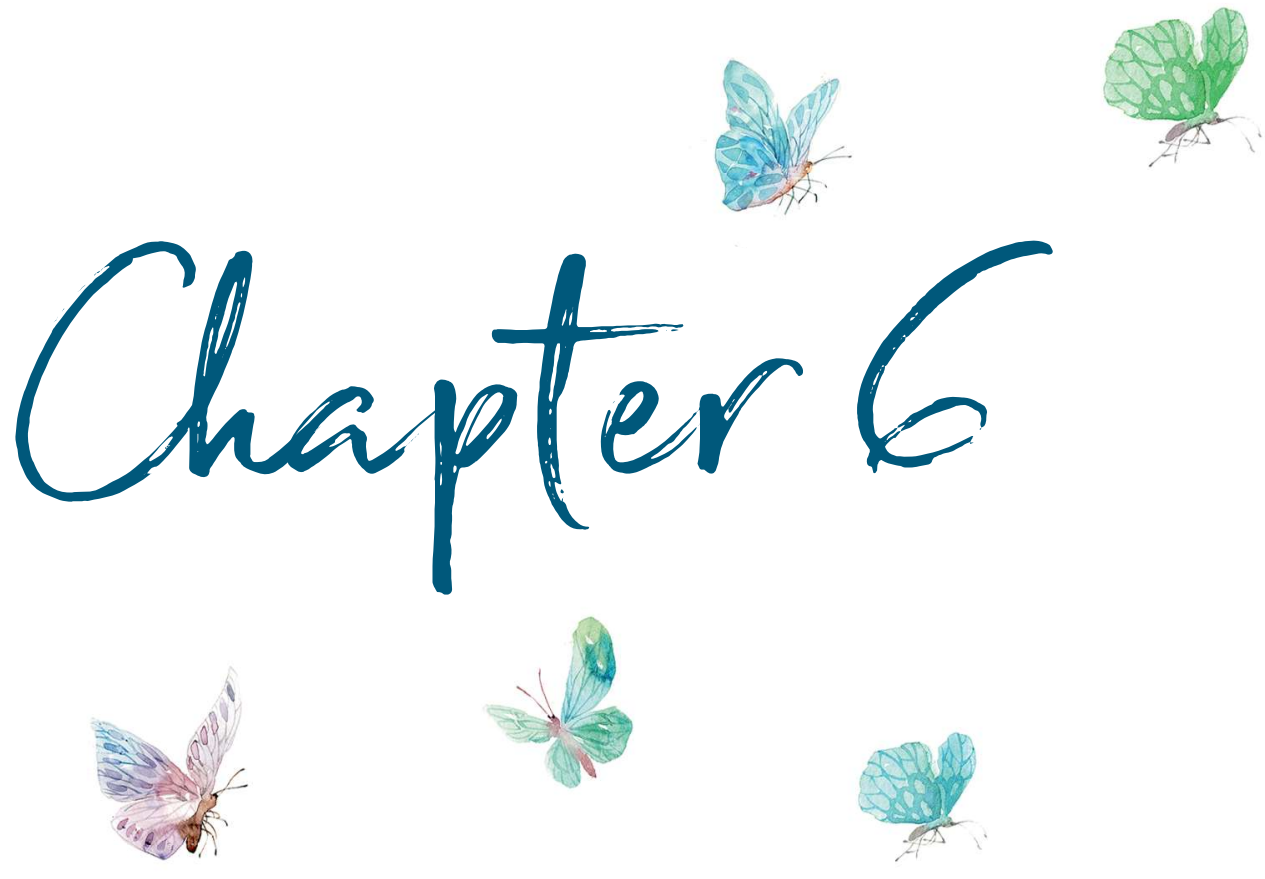




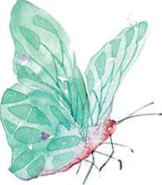

\section{The minimum clinically important difference (MCID): which direction to take}




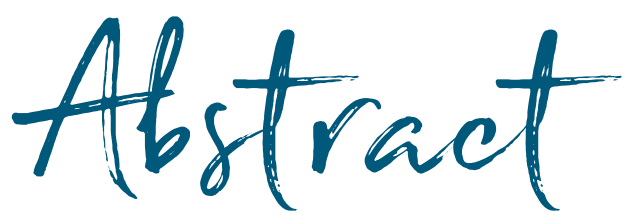

Over the past decades in modern medicine, there has been a shift from statistical significance to clinical relevance when it comes to interpreting results from clinical trials. A concept that is increasingly being used as a surrogate for clinical relevance and effect size calculation is the minimum clinically important difference (MCID). In this paper, we will present an overview of the most important aspects of the MCID concept used in research trials and we will discuss what this means for the neurological patient in clinical trials and daily practice. Is the MCID the best outcome measure cut-off to be implemented? 


\section{INTRODUCTION}

The need for evidence-based medicine is greater than it ever has been before. In accordance, there is a great need for outcome measures which fulfil modern clinimetric requirements such as validity, reliability and responsiveness and solely represent a level of assessing outcome as postulated by the ICF (International Classification of Functioning, Disability, and Health) concept (1).

Rating scales are frequently used as an outcome measurement in both daily neurological practice as well as many clinical trials. An example is the Modified Rankin Scale, an ordinal scale consisting of 7 items running from no symptoms (0) to death (6), a commonly used outcome measurement in stroke trials like the ' $\mathrm{Mr}$ Clean' study regarding endovascular treatment of ischemic stroke (2).

Another example is the Unified Parkinson's Disease Rating Scale (UPDRS) which was used as a primary outcome in the Adagio study for the effect of Rasagiline in Parkinson's disease (3). The UPDRS is also an ordinal scale with a range of 0 to 176 points in which a higher score indicates more severity.

The list with similar examples in daily practice and clinical trials is endless. However, when researchers do not correlate a statistically significant study result from its clinical relevance point of view, this could lead to misinterpreting results showing falsely positive findings and exposing patients unnecessarily to therapies (4). Fortunately, over the past decades there has been a shift from statistical significance to clinical relevance when it comes to interpreting results from clinical trials (5-7).

Although the term 'clinical relevance' seems to be straightforward, it is not easy to define and to quantify. Who decides what is clinically relevant, the patient and/or the clinician? And how does one deal with different views on clinical relevance between patients? As an example, imagine two patients (A and B), both bedridden due to Guillain-Barré syndrome (GBS). Patient A is an elderly patient, who considers 'being able to walk with aid' as a clinically relevant improvement. Patient B is a young adult, who considers 'being able to compete in professional sports again' as a clinically relevant change. Both are affected by the same disease and are functioning on a similar level. Yet, they have different interpretation of the term 'clinical relevance' and will have different goals for their treatment. The same could be applied to differences between clinicians in terms of interpreting the significance of minimum clinically important difference (MCID).

And even if we could reach a consensus on what would be a clinically relevant change, we still would need a proper outcome measure to be able to detect that change. When these changes are vast and our study population is large, then an instrument will have 
little to no problem detecting such a change. However, changes are more likely to be subtle, and sometimes can be shrouded by the natural fluctuating disease course or other confounding factors. In these cases, we need proper outcome measures to detect these smaller, but clinically relevant changes and differentiate these changes from fluctuating "noise" variations seen in illnesses. Subsequently, we need to reach consensus on how to determine when a change is relevant enough to call the trial a success and not simply let this being driven by the p-value hypothesis approach. In essence, is a trial successful by only looking at a statistical significant p-value, like the Adagio study (3)? Or do we use a standardized cut-off point, like being able to walk independently as was done in GBS trials (8)? Another option would be to determine the MCID as was done in a follow-up analysis of the results of the ICE trial in patients with inflammatory neuropathies (6).

In this paper, we will provide an overview of the MCID concept striving to help neurologists become more familiar with this entity. We will discuss the origin of the MCID, its variable faces, and methods on how to determine its cut-off as well as pitfalls when applying this concept.

Finally, we will provide recommendations regarding its use in future clinical studies and trials.

\section{MCID: Origin}

The term MCID was first defined by Jaeschke et al as 'the smallest difference in score in the domain of interest which patients perceive as beneficial and which would mandate, in the absence of troublesome side effects and excessive cost, a change in the patient's management' (9). Over time, a mix of various definitions have been adopted for the MCID concept, such as the minimal important difference (MID), the minimally important change (MIC), the minimally detectable difference (MDD), the minimum detectable change $(\mathrm{MDC})$, etcetera $(10,11)$. All these adaptations have a common denominator aiming to quantify changes that are considered clinically relevant.

Another related term is the patient acceptable symptom state (PASS), which was defined as 'the value beyond which patients consider themselves well' (12). These authors state that the MCID deals with the concept of improvement (feeling better) whereas the PASS deals with the concept of wellbeing (feeling good), thus also being complementary to the MCID.

\section{MCID: Methods}

The MCID concept is generally categorized into two main streams: the anchorbased and distribution-based methods $(13,14)$. Extensive information regarding these (and newer) methods have been published in several excellent reviews (15-17). 


\section{Anchor-based}

Anchor-based methods involve comparing the change in the situation of a patient as captured by an outcome measure to an external criterion. This external criterion is often a patient's own categorisation of their personal change, e.g. after an intervention. Examples of this method are using a pain score like the visual analogue scale (VAS), or a patient global impression of change scale (much worse, somewhat worse, about the same, somewhat better, much better).

Most often researchers will look at the change in a single patient over time, the so called 'within-patient' change (18). In a study population, the group who scored 'somewhat better' or 'much better' is at interest since these people have informed the researcher they have clinical improvement (from the patient's point of view). Next step is to look at the (median) change of the score of the instrument used that is representing the level of assessment of interest, which is often considered as the minimum change that correlates with clinical improvement.

Another anchor-based method is looking between patients at a single point in time, the so called 'between-patient' (18). Patients are grouped based on their rating on the external criterion: for example pain ('I have no pain, I have moderate pain, I have extreme pain'). Next, one would look at the (median) scores of the instrument of interest in these groups and then determine the MCID as the difference between the median score of the groups 'I have moderate pain' and 'I have no pain'.

Less commonly used adaptions are a combination of the within-person and betweenperson and a method in which patients rate their health state in comparison to other patients (19).

\section{Distribution-based}

Distribution-based MCID methods are built upon the statistical properties of a study's result (20). These include both the effect size, where the mean change of the individual is divided by the variability of either the whole group or the subset of stable subjects, and the reliability change index, a statistic rooted in the standard error of measurement (SEM) (21). The SEM is a measure of the variation of observed scores due to measurement error compared to the "true" score. Any changes which are below the SEM could be due to a measurement error "noise" rather than to a truly occurring change. The number of SEMs needed to qualify a change in a patient's score to be meaningful is not yet fully established $(16,17)$. The most compelling argument has been provided by Wyrwich, who states that the 'one-SEM criterion holds promise for identifying clinically meaningful intra-individual change $(21,22)$. 
The standard deviation (SD) is a measure that is used to quantify the amount of variation or dispersion of a set of data values. In multiple studies with different outcome measures there seemed to be a universally applicable rule of thumb that the MCID is equal to $0.5 \mathrm{SD}(23)$.

\section{MCID: Pitfalls}

When using and interpreting MCID values, one should always take several considerations into account, of which some are addressed in the following.

\section{Use of ordinal scales}

The use of ordinal scales is widespread across modern medicine, even though their shortcomings have been known for a long time (24). Modern techniques like the Rasch model can help transform ordinal scales to interval-based scales $(25,26)$. Ordinal scales are often treated as an interval-based scale. However, one of the major problems with ordinal scales is that the amount of change required on a 10-point scale to go from 2 to 4 is not always the same as to go from 6 to 8 . Therefore, the lack of a fixed unit using a metric as such hampers the stability definition of MCID across its range and the proper interpretation of the final results, which could subject patients to false positive or false negative results.

\section{Small, but clinically relevant changes}

Distribution-based methods define the MCID as a change bigger than the expected variation or error in measurement. It isn't however beyond the point of imagination to suggest a clinically relevant change that lies within the variation of a measurement, especially when the variation of a measurement has a wide range. All these relevant changes won't be noted because they are considered changes due to variation of the measurement rather than due to clinical real change.

\section{Static value for a dynamic concept}

Ideally, one would be able to use a fixed MCID cut-off for each instrument for all patients in clinical studies. However, since the MCID is a dynamic concept, this is not a realistic thought. Patients' (individual) MCID will vary by the severity of their illness, their social status, their own concepts of health and improvement, etcetera. Furthermore, the MCID can be different for different treatments in the same patient group. For a surgical intervention with high risk and long recovery, a patient will expect more improvement for it to be clinically relevant and to warrant this treatment than for example when the patient only needs to make a minor adjustment in his lifestyle. So when examining a new treatment, one can't just blindly copy an MCID determined in a different study with different treatments. 


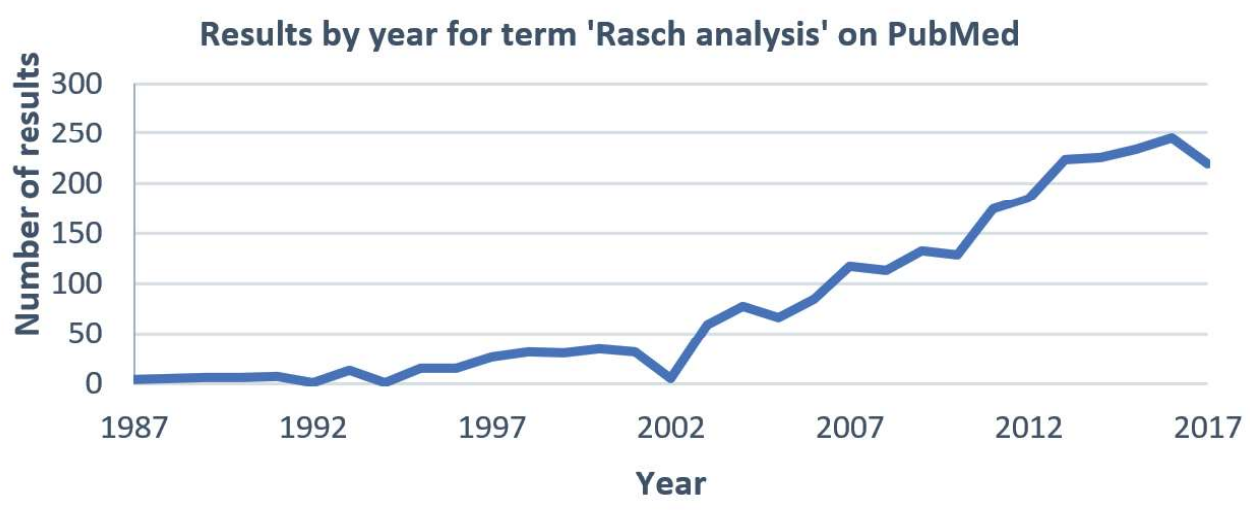

FIGURE 1: graphical display of the amount of hits on PubMed for the term 'Rasch analysis'.

\section{MCID doesn't account for cost-benefit}

Although the classic definition by Jaeschke et al did incorporate cost " in the absence of ... excessive cost"), the MCID values determined nowadays do not take into account the cost of a specific treatment. In the light of the widespread pressure on funds for health care, it seems justified to take the cost of a certain amount of change into account as well, before establishing a change to be an MCID.

\section{MCID: Rasch improvements}

The Rasch model is a modern technique that helps transform ordinal data to interval data. The term modern is relative: the first publication on its theory dating from 1960 (25). It is being applied increasingly in research in modern medicine over the past decades (Figure 1).

The Rasch model states that "a person having a greater ability than another person should have the greater probability of solving any item of the type in question, and similarly, one item being more difficult than another means that for any person the probability of solving the second item is the greater one". So in short: the person with a higher ability (thus being less ill) has a higher chance of getting a higher score. See also Figure 2 for a graphic illustration of this concept. This means that a confirmation on an item depends on both the difficulty of the item and the ability of the person. For more in-depth information, we refer readers to other publications $(27,28)$.

The Rasch model can help improve the MCID. One way is to transform the ordinal data to interval data, as stated above. This removes the obstacle of score changes to be different across the scale (an example is a change from 2 to 4 is not necessarily 


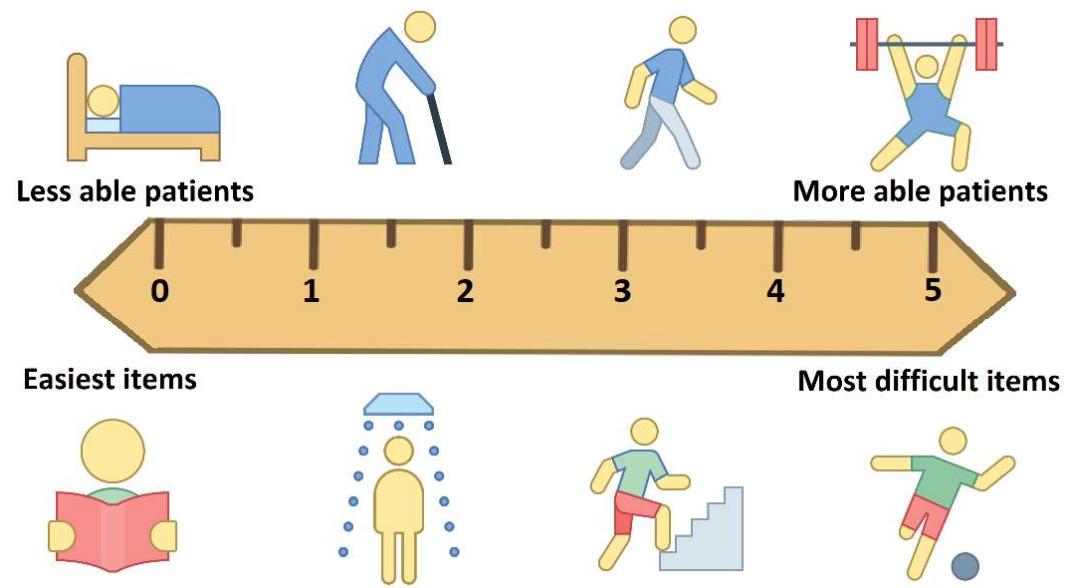

FIGURE 2: Visualisation of the Rasch model.

The probability of an item response depends on both the ability of a patient as well as the difficulty of an item.

the same as 8-10 on an ordinal scale), since on an interval scale the increment along the scale is equal for each step. Applying the Rasch model is mostly beneficial if the original (ordinal) scale does not behave in a linear fashion.

Additionally, after applying the Rasch model, one can determine the individual standard error (SE) of the ability estimate of each individual patient. This allows for individually determined MCIDs based on the patient's own SE. This is important because the SE of the ability of a patient varies across the range of said ability. In general, patient with either a low or high ability score have a higher SE, while patient with an average score will have a lower SE. This shows one cannot just take a single MCID cut-off value to be applied to all patients equally. For more detail on this, we refer to an extensive report by Hobart and Cano, in particular Chapter 8 (29).

\section{Recommendations and future perspectives}

For clinical research trials to advance, one should always consider if the pre-defined primary outcome truly is clinically relevant to our patients and that the method of determining that outcome is up to current modern clinimetric standards.

Before determining the MCID of a rating scale, one should take caution of the nature of the scale. If it is an ordinal scale (behaving in a non-linear fashion), one should apply the Rasch model to create an interval-based scale, as mentioned above. This will also allow for individual MCIDs to be determined, furthering the ability of establishing responsiveness in individual patients and capturing their voice more accurately. 
We also strongly discourage researchers using previously established MCID cut-off values when setting up new trials if the intervention, outcome measure and patient population aren't similar to the settings in which the MCID cut-off was established.

The current paper provides the neurological community a brief overview on the meaning of the MCID. Despite all the limits, pitfalls and controversy on how to determine the MCID, its concept is of great importance in modern clinical trials. As long as no consensus is reached on which method to use, we recommend using an anchor-based alongside a distribution-based method, which should be seen complementary to each other rather than separately. Furthermore, by examining both methods, one can also compare the two methods in terms of their dynamics and results. Finally, by applying an anchor-based method with for example a selfevaluation of one's health, one can also capture the opinion of the patient. After all, isn't the patient's perspective on their own health, be it improvement, deterioration or maintenance, that which should be the most important outcome measure in clinical trials?

A relative new trend regarding this aspect is the inclusion of patients (and their caregivers) in clinical trial design as part of the study team. This can lead to a better understanding of the scope of which a disease can impact a patient's life. In doing so, previously neglected outcome domains, such as fatigue or sleep disturbances, can be identified and corrected (30-32).

Perhaps a next step would be to let the patients themselves tell us what they would deem as a sufficient amount of change on their health status for a treatment to be qualified as successful. This would surely be easier than constructing intricate surrogate markers with dubious clinimetric qualities which most clinicians struggle to comprehend. Simply talking and, more importantly, listening to our patients however is something every clinician excels at and perhaps researchers should start doing more and more. 


\section{REFERENCES}

1. World Health Organization. International classification of functioning, disability and health : ICF. Geneva: World Health Organization; 2001. iii, 299 p. p.

2. Fransen PS, Berkhemer OA, Lingsma HF, Beumer D, van den Berg LA, Yoo AJ, et al. Time to Reperfusion and Treatment Effect for Acute Ischemic Stroke: A Randomized Clinical Trial. JAMA Neurol. 2016;73(2):190-6.

3. Olanow CW, Rascol O, Hauser R, Feigin PD, Jankovic J, Lang A, et al. A double-blind, delayedstart trial of rasagiline in Parkinson's disease. N Engl J Med. 2009;361(13):1268-78.

4. Stang A, Poole C, Kuss O. The ongoing tyranny of statistical significance testing in biomedical research. Eur J Epidemiol. 2010;25(4):225-30.

5. Kemmler G, Zabernigg A, Gattringer K, Rumpold G, Giesinger J, Sperner-Unterweger B, et al. A new approach to combining clinical relevance and statistical significance for evaluation of quality of life changes in the individual patient. J Clin Epidemiol. 2010;63(2):171-9.

6. Merkies IS, van Nes SI, Hanna K, Hughes RA, Deng C. Confirming the efficacy of intravenous immunoglobulin in CIDP through minimum clinically important differences: shifting from statistical significance to clinical relevance. J Neurol Neurosurg Psychiatry. 2010;81(11):1194-9.

7. Terwee CB, Terluin B, Knol DL, de Vet HC. Combining clinical relevance and statistical significance for evaluating quality of life changes in the individual patient. J Clin Epidemiol. 2011;64(12):1465-7; author reply 7-8.

8. van Koningsveld R, Schmitz PI, Meche FG, Visser LH, Meulstee J, van Doorn PA, et al. Effect of methylprednisolone when added to standard treatment with intravenous immunoglobulin for Guillain-Barre syndrome: randomised trial. Lancet. 2004;363(9404):192-6.

9. Jaeschke R, Singer J, Guyatt GH. Measurement of health status. Ascertaining the minimal clinically important difference. Control Clin Trials. 1989;10(4):407-15.

10. King MT. A point of minimal important difference (MID): a critique of terminology and methods. Expert Rev Pharmacoecon Outcomes Res. 2011;11(2):171-84.

11. Beaton DE, Boers M, Wells GA. Many faces of the minimal clinically important difference (MCID): a literature review and directions for future research. Curr Opin Rheumatol. 2002;14(2):109-14.

12. Tubach F, Ravaud P, Baron G, Falissard B, Logeart I, Bellamy N, et al. Evaluation of clinically relevant states in patient reported outcomes in knee and hip osteoarthritis: the patient acceptable symptom state. Ann Rheum Dis. 2005;64(1):34-7.

13. Redelmeier DA, Guyatt GH, Goldstein RS. Assessing the minimal important difference in symptoms: a comparison of two techniques. J Clin Epidemiol. 1996;49(11):1215-9.

14. Lydick E, Epstein RS. Interpretation of quality of life changes. Qual Life Res. 1993;2(3):221-6. 
15. Wells G, Beaton D, Shea B, Boers M, Simon L, Strand V, et al. Minimal clinically important differences: review of methods. J Rheumatol. 2001;28(2):406-12.

16. Copay AG, Subach BR, Glassman SD, Polly DW, Jr., Schuler TC. Understanding the minimum clinically important difference: a review of concepts and methods. Spine J. 2007;7(5):541-6.

17. Revicki D, Hays RD, Cella D, Sloan J. Recommended methods for determining responsiveness and minimally important differences for patient-reported outcomes. J Clin Epidemiol. 2008;61(2):102-9.

18. Kirshner B, Guyatt G. A methodological framework for assessing health indices. J Chronic Dis. 1985;38(1):27-36.

19. Wells GA, Tugwell P, Kraag GR, Baker PR, Groh J, Redelmeier DA. Minimum important difference between patients with rheumatoid arthritis: the patient's perspective. J Rheumatol. 1993;20(3):557-60.

20. Sloan J, Symonds T, Vargas-Chanes D, Fridley B. Practical Guidelines for Assessing the Clinical Significance of Health-Related Quality of Life Changes within Clinical Trials. Drug Inf J. 2003;37(1):23-31.

21. Wyrwich KW, Nienaber NA, Tierney WM, Wolinsky FD. Linking clinical relevance and statistical significance in evaluating intra-individual changes in health-related quality of life. Med Care. 1999;37(5):469-78.

22. Wyrwich KW, Tierney WM, Wolinsky FD. Further evidence supporting an SEM-based criterion for identifying meaningful intra-individual changes in health-related quality of life. J Clin Epidemiol. 1999;52(9):861-73.

23. Norman GR, Sloan JA, Wyrwich KW. Interpretation of changes in health-related quality of life: the remarkable universality of half a standard deviation. Med Care. 2003;41(5):582-92.

24. Stevens SS. On the Theory of Scales of Measurement. Science. 1946;103(2684):677-80.

25. Rasch G. Probabilistic Models for Some Intelligence and Attainment Tests. Chicago: University of Chicago Press. 1960.

26. Wright $\mathrm{BD}$, Linacre JM. Observations are always ordinal; measurements, however, must be interval. Arch Phys Med Rehabil. 1989;70(12):857-60.

27. Tennant A, Conaghan PG. The Rasch measurement model in rheumatology: what is it and why use it? When should it be applied, and what should one look for in a Rasch paper? Arthritis Rheum. 2007;57(8):1358-62.

28. Vanhoutte EK, Hermans MC, Faber CG, Gorson KC, Merkies IS, Thonnard JL, et al. Raschionale for neurologists. J Peripher Nerv Syst. 2015;20(3):260-8.

29. Hobart J, Cano S. Improving the evaluation of therapeutic interventions in multiple sclerosis: the role of new psychometric methods. Health Technol Assess. 2009;13(12):iii, ix-x, 1-177. 
30. Collins SP, Levy PD, Holl JL, Butler J, Khan Y, Israel TL, et al. Incorporating Patient and Caregiver Experiences Into Cardiovascular Clinical Trial Design. JAMA Cardiol. 2017;2(11):1263-9.

31. de Wit M, Abma T, Koelewijn-van Loon M, Collins S, Kirwan J. Involving patient research partners has a significant impact on outcomes research: a responsive evaluation of the international OMERACT conferences. BMJ Open. 2013;3(5).

32. Abma TA, Nierse CJ, Widdershoven GA. Patients as partners in responsive research: methodological notions for collaborations in mixed research teams. Qual Health Res. 2009;19(3):401-15. 
The MCID | 95 

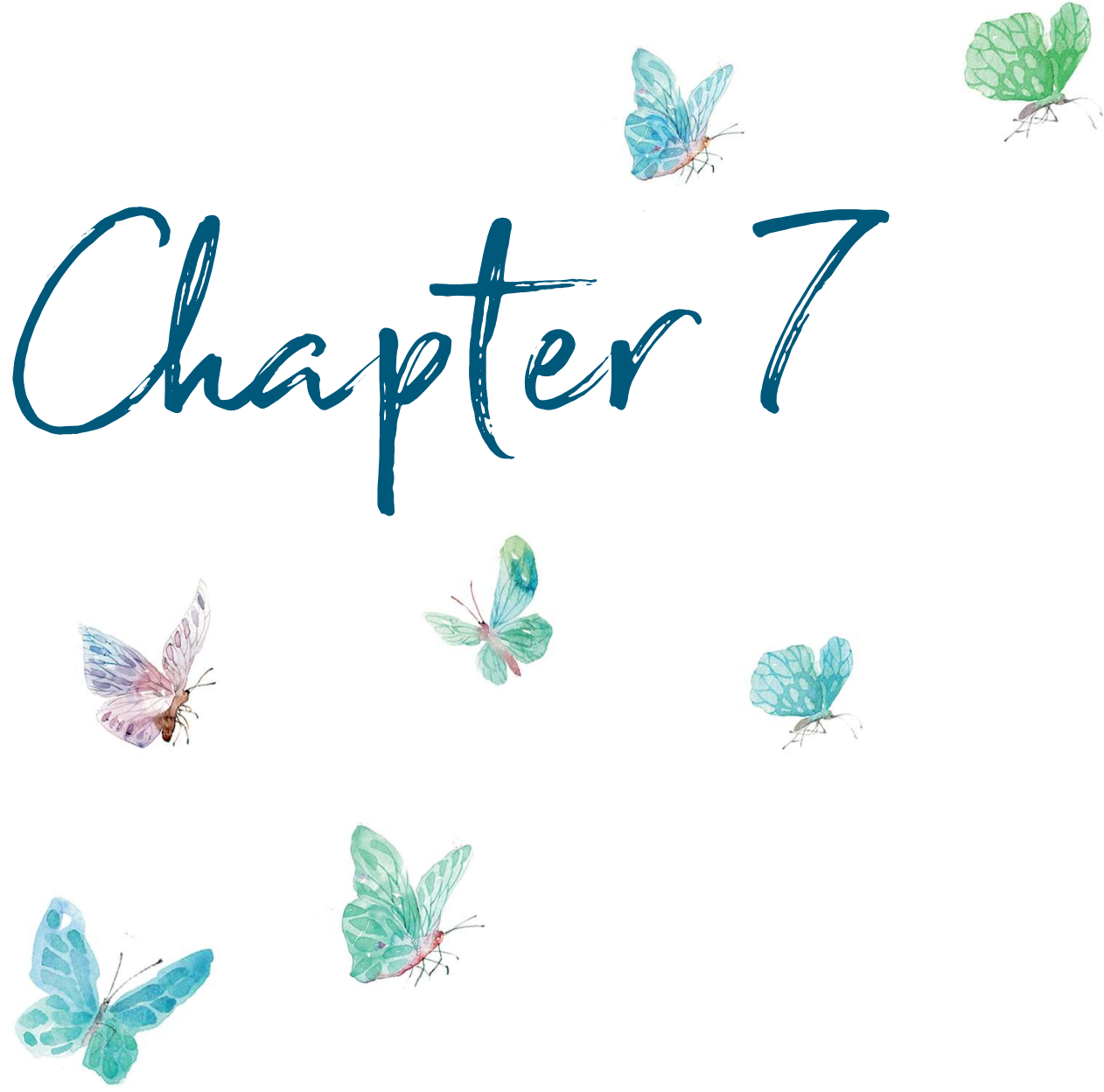


\section{General discussion and future perspectives}


The PeriNomS study has been an enormous effort for everyone involved, and more specifically for the participating patients. The results have been equally impactful in multiple ways.

Normative values for two-point discrimination assessment and grip strength were established. $(1,2)$ Existing outcome measures have been critically appraised and improved where possible (the modified Rasch-built fatigue severity scale (3), grip strength $(4,5)$, the ability to walk (6) and the MRC grading scale (7)).

New outcome measures that fulfil all modern clinimetric standards have been developed on the activity/participation level (the I-RODS $(8,9)$, the MMNRODS(10)) as well as a quality of life scale (the IN-QoL (11)).

But, perhaps even more importantly, we have gained insight into modern clinimetric standards, the concepts of responsiveness and being a responder. By applying these insights on the data of the PeriNomS study, we have been able to show the added value of these concepts in clinical trials and daily practice. The importance of these concepts go well beyond the field of inflammatory neuropathies.

Although it has been (and still is) difficult to generate a shift in the neurological community to abandon the firmly rooted concepts of statistical significance and the use of ordinal scales, this has not withheld members of the PeriNomS study group to keep spreading this gained knowledge through organized meetings, congresses and publications in high-quality medical journals. (1-21)

In this chapter, we will discuss several key points of this thesis as well as comment on future perspectives.

We determined the responsiveness for several outcome measures inflammatory neuropathies. Responsiveness is the ability to detect change over time. To determine responsiveness, several parameters must be accounted for.

First, one would need an illness that actually shows changes over time, either due to its natural course or to treatment. The greater the amount of chance, the easier an outcome measure will be able to capture this change.

Second, one needs a sufficient time-span for the change to occur. In the studies included in this thesis, patients with MGUSP and MMN showed to be far less or even not responsive at all (Chapter 2 and Chapter 5). By choosing too short a time window for the change to occur, no treatment or trial will ever be able to be successful. Also, by choosing a short time window perhaps only short term effects are measured, qualifying a treatment as success, even though a relapse might occur afterwards or on the long term, meaning the treatment would have no influence at all on the natural course of the disease.

Third, one needs to determine what the goal of your study will be, and what aspect of the disease you want to measure change in. In inflammatory neuropathies one 
could be interested in raw muscle strength, daily functioning and/or the quality of life. However, changes that occur in a patient are often multifaceted, having impact on the physical, mental and social functioning of a person, with each facet having an impact on the others as well. By narrowing a patient down to only a single construct one will not be able to capture the whole spectrum of functional limitations perceived by these patients in daily and social practice. This was shown in this thesis for 'the ability to walk' (Chapter 3).

Fourth, one will need to determine what outcome measure you are going to use. Throughout this thesis the need for proper outcome measures is mentioned, fulfilling modern clinimetric standards like the Rasch model to avoid improper conclusions to be drawn. The deficits of ordinal scales are well described in the literature, though somehow clinicians continue to use ordinal measures in clinical trials despite their known constraints.(22-26) Several facets may explain the improper use of ordinal measures:

- Most neurologists consider observations in a clinical setting as real measurements, and usually are unaware that quantitative observations are based on counting observed events, while meaningful measurements are based on the arithmetical properties of interval or ratio scales. Observations are ordinal and provide a good description of the clinical question of interest. The problem arises when we start giving the ordinal descriptions numbers arbitrarily, create sum scores, treating these scores as linear, and make assumptions from the findings.

- The current medical curriculum does not provide training in clinimetrics, and therefore, the exposure of this knowledge to physicians is relatively poor. Subsequently, the risk of drawing incorrect conclusions from trials with ordinal measures as the primary outcome becomes high, but this remains generally unacknowledged

- When exposed to modern methods such as the Rasch model, many physicians may feel uncomfortable and opposed to these techniques mostly because of their less accessible arithmetical properties. This may contribute to a "holding-on attitude" of physicians to the seemingly more intuitive, but less proper, ordinalbased measures.

The use of patient-reported outcome measures (PROMs) are by now common in modern medicine. However, the use of these subjective outcome measures as primary end point in clinical trials is controversial due to concerns about their validity, reliability and objectivity. (27-29) This has caused a certain amount of reluctancy amongst investigators to use them in clinical trials.

We have shown that a subjective measure like the I-RODS correlates very well with an objective measure like grip strength in inflammatory neuropathies (Chapter 4). A solution to the reluctancy of using PROMs by investigators is to apply correlation studies with objective measurements to help show the robustness of these PROMs. 
Fifth, one would need to determine what or who to call a 'responder'. Assuming you have a construct in which you can accurately detect the change in a patient, one needs to define how much change is enough to be qualified a responder. Since the concept of being a responder is quite pivotal, we will expand on this concept some more.

The amount of change needed to be deemed a responder should be a 'clinically relevant' change, rather than 'statistically significant'. The need to shift from statistically significant to clinically relevant is already well known amongst researchers and clinicians.(16, 30-33) However there still seems to be a lack of proper outcome measures and interpreting study results allowing to truly conclude something as 'clinically relevant'. Therefore, we have written a short review regarding this subject by explaining the MCID concept (Chapter 6). Furthermore, we have described the use of the MCID-SE method to determine responsiveness (Chapter 2 and Chapter 5).

The definition of a responder should be redefined for each clinical trial: it is intrinsically linked to the disease state, disease progression, the intervention, and to the patient as an individual. For clarification, we pose several examples.

A 25-year old and an 80-year old GBS patient with equal severity (e.g. bedridden) who both improve equally (able to walk with aid) after intervention (IVIg treatment). The 25-year old might not feel his treatment as a success, since he cannot walk unaided, whereas the elderly patient might see it as success since he is able to walk again, despite having to use an aid in doing so. Without seeing the patients as individuals, one might determine them both as (non-)responder if only considering their improvement.

A 30-year old patient with a herniated disc on the lumbar level is offered non-surgical and surgical treatment. If this would be a clinical trial, an outcome measure could be the pain VAS score pre- and post-treatment with a certain follow-up duration. A responder could be defined as ' $30 \%$ reduction on the VAS score', and the primary outcome would be comparison of the responder rate between the two interventions. However, the patient might judge the surgical treatment only to be successful if there is at least $50 \%$ pain reduction due to the more invasive nature and higher complication risk. Equally, the patient might require a $20 \%$ pain reduction if the intervention is a minor adjustment in his lifestyle (physiotherapy once a week for 1 hour). One cannot blindly apply equal definitions of responsiveness on different interventions without critically evaluating the impact of the interventions first. 
In this theses, we have defined responsiveness as MCID-SE $\geq 1.96$ for inflammatory neuropathies using the I-RODS and IN-QoL (Chapter 2 and Chapter 5). Patients with MMN and MGUSP showed little to no responsiveness, or even a trend towards deterioration (Chapter 5). Perhaps the definition of a responder in these illnesses should not be to improve but rather to stabilise / not deteriorate. This could also be applied to other progressive, chronic diseases like Parkinson's Disease or Alzheimer's Dementia, depending on the nature of the study/intervention, and in those cases an MCID-SE of $\geq 1.00$ may be more appropriate.

\section{FUTURE PERSPECTIVES}

The outcome measures which are presented in the earlier parts of the PeriNomS study as well as in thesis still have some limitations, and many parts need further studies. One of these is cross-cultural applicability, as some items of the I-RODS has shown to have item bias based on the geographic region (8), and for the IN-QoL this has not yet been examined. Furthermore, since the IN-QoL was newly developed, this questionnaire has not yet been examined in a prospective setting, which could give better insights to its applicability in daily practice as well as confirmation on its clinimetric properties. Also, the questionnaire still exists of 73 items, which is still somewhat extensive. By testing the scale in a prospective setting with sufficient patients in each disease category as well as cultural categories we feel the IN-QoL very well could be reduced down to less items without sacrificing its ability to capture change and see how well it holds up cross-culturally.

Regarding the follow-up duration, it was seen that a 1-year period was too short, especially for MGUSP and MMN patients. Preferably we would suggest at least 2-year, if not longer, follow-up duration for these more indolent-coursed diseases.

In terms of defining a responder, we have taken a first step in truly including our patients in determining whether a trial or treatment is successful. The use of the patients own health rating (the EuroQoL thermometer in Chapter 2 and Chapter 5) has shown us the strength of the patient's own view on their health. One should be aware though of the pitfall of using a Visual Analogue Scale (VAS) as an outcome measure. A VAS format, usually ranging from 1-10 or 1-100, will give the suggestion of an interval or ratio level of data. However, as has been demonstrated, these scales also have the risk of acting as ordinal scales, resulting in disordered thresholds. (34, 35) To avoid this pitfall, one can use the Rasch model to examine how the used analogue scale behaves. 
A next step would be to let the patient tell us how much improvement they would like to achieve, and let the patient tell us the 'cut-off' point to help determine what is success, rather than a cut-off point based on a clinician 'expertise' or a statistical method like p-value or the distribution-based methods of the MCID.

One would first need to incorporate several outcome measures and methods of defining a responder before determining what the best outcome measure(s) or definition of a responder is.

Efforts are being undertaken to make the use of our developed outcome measures more easily accessible for daily practice for both the clinician as well as our patients. A web- and app-based version of the I-RODS is currently being constructed.

Furthermore, a follow-up study, the PeriNomS part II, is currently under development, in which the above mentioned shortcomings and voids will be incorporated to further establish our knowledge and improve our outcome measures.

\section{CONCLUSIONS REGARDING FUTURE STUDIES}

We would recommend any investigator to first gain knowledge on outcome measures, responsiveness and how to define a responder before venturing forth in the field of clinical trials. Do not use existing outcome measures solely based on their use in previous similar trials, but keep questioning if the selected outcome measures truly reflect the change you want to measure.

For inflammatory neuropathies in particular, we can now recommended a core-set of outcome measures to be used in future trials:

- Impairment: for muscle strength a muscle dynamometer has been shown to be a responsive tool with a strong correlation with an outcome measure on the activity/participation level. $(5,12)$

The MRC sum score remains an outcome measure which is still commonly used in clinical trials in neuromuscular disorders, despite its known deficits and attempts to modify it. (36-40) An alternative has been presented, which was constructed using the Rasch method, elevating it from an ordinal scale to an interval scale and fulfilling many required clinimetric properties. (7) This Raschtransformed MRC sumscore has not seen use in clinical trials yet, which could be seen as a shortcoming in the neuromuscular research field.

- Activity and participation: the I-RODS has been demonstrated to be the best outcome measure in inflammatory neuropathies to reflect activity and 
participation in this patient population. Further efforts should be undertaken to construct similar scales for other neuromuscular disorders.

- Quality of life: the IN-QoL is at the moment the only interval-based questionnaire which specifically was designed for inflammatory neuropathies. It's limitations (no cross-cultural validation, not prospectively examined) should not withstand the use in future clinical trials in inflammatory neuropathies.

The EuroQoL thermometer proved to be an invaluable tool in determining responsiveness as well as its easy applicability should warrant mandatory use of this outcome measure in future clinical trials.

Finally, for defining a responder, we would recommended using both an anchorbased as well as a distribution-based method (MCID-SE). In addition, we should start including patient's own goals regarding the impairment, activity/participation and/or quality of life and see how well these correlate with our existing definitions of a responder.

It is our belief that these correlation might surprise us, resulting in making many tedious and strenuous outcome measures redundant. We might be able to simply ask our patient 1) how they are doing currently and 2) what their goals are after our intervention. 


\section{REFERENCES}

1. Peters MJ, van Nes SI, Vanhoutte EK, Bakkers M, van Doorn PA, Merkies IS, et al. Revised normative values for grip strength with the Jamar dynamometer. Journal of the peripheral nervous system : JPNS. 2011;16(1):47-50.

2. van Nes SI, Faber CG, Hamers RM, Harschnitz O, Bakkers M, Hermans MC, et al. Revising twopoint discrimination assessment in normal aging and in patients with polyneuropathies. Journal of neurology, neurosurgery, and psychiatry. 2008;79(7):832-4.

3. van Nes SI, Vanhoutte EK, Faber CG, Garssen M, van Doorn PA, Merkies IS, et al. Improving fatigue assessment in immune-mediated neuropathies: the modified Rasch-built fatigue severity scale. Journal of the peripheral nervous system : JPNS. 2009;14(4):268-78.

4. Draak TH, Pruppers MH, van Nes SI, Vanhoutte EK, Bakkers M, Gorson KC, et al. Grip strength comparison in immune-mediated neuropathies: Vigorimeter vs. Jamar. Journal of the peripheral nervous system : JPNS. 2015;20(3):269-76.

5. Vanhoutte EK, Latov N, Deng C, Hanna K, Hughes RA, Bril V, et al. Vigorimeter grip strength in CIDP: a responsive tool that rapidly measures the effect of IVIG--the ICE study. European journal of neurology. 2013;20(5):748-55.

6. Draak TH, Gorson KC, Vanhoutte EK, van Nes SI, van Doorn PA, Cornblath DR, et al. Does ability to walk reflect general functionality in inflammatory neuropathies? Journal of the peripheral nervous system : JPNS. 2016;21(2):74-81.

7. Vanhoutte EK, Faber CG, van Nes SI, Jacobs BC, van Doorn PA, van Koningsveld R, et al. Modifying the Medical Research Council grading system through Rasch analyses. Brain : a journal of neurology. 2012;135(Pt 5):1639-49.

8. Draak TH, Vanhoutte EK, van Nes SI, Gorson KC, Van der Pol WL, Notermans NC, et al. Changing outcome in inflammatory neuropathies: Rasch-comparative responsiveness. Neurology. 2014;83(23):2124-32.

9. van Nes SI, Vanhoutte EK, van Doorn PA, Hermans M, Bakkers M, Kuitwaard K, et al. Raschbuilt Overall Disability Scale (R-ODS) for immune-mediated peripheral neuropathies. Neurology. 2011;76(4):337-45.

10. Vanhoutte EK, Faber CG, van Nes SI, Cats EA, Van der Pol WL, Gorson KC, et al. Rasch-built Overall Disability Scale for Multifocal motor neuropathy (MMN-RODS((c))). Journal of the peripheral nervous system : JPNS. 2015;20(3):296-305.

11. Draak THP, Faber CG, Merkies ISJ, PeriNom SsG. Quality of life in inflammatory neuropathies: the IN-QoL. Journal of neurology, neurosurgery, and psychiatry. 2018;89(3):256-62.

12. Draak TH, Gorson KC, Vanhoutte EK, van Nes SI, van Doorn PA, Cornblath DR, et al. Correlation of the patient's reported outcome Inflammatory-RODS with an objective metric in immune-mediated neuropathies. European journal of neurology. 2016;23(7):1248-53. 
13. Draak TH, Vanhoutte EK, van Nes SI, Gorson KC, Van der Pol WL, Notermans NC, et al. Comparing the NIS vs. MRC and INCAT sensory scale through Rasch analyses. Journal of the peripheral nervous system : JPNS. 2015;20(3):277-88.

14. Pruppers MH, Draak TH, Vanhoutte EK, Van der Pol WL, Gorson KC, Leger JM, et al. Outcome measures in MMN revisited: further improvement needed. Journal of the peripheral nervous system : JPNS. 2015;20(3):306-18.

15. Vanhoutte EK, Draak TH, Gorson KC, van Nes SI, Hoeijmakers JG, Van der Pol WL, et al. Impairment measures versus inflammatory RODS in GBS and CIDP: a responsiveness comparison. Journal of the peripheral nervous system : JPNS. 2015;20(3):289-95.

16. Vanhoutte EK, Faber CG, Merkies IS. [Statistical significance or clinical relevance?]. Ned Tijdschr Geneeskd. 2010;154:A2516.

17. Vanhoutte EK, Faber CG, Merkies IS, PeriNom SSG. MRC sum-score in the ICU: good reliability does not necessarily reflect "true reliability". Muscle \& nerve. 2012;45(5):767-8; author reply 8-9.

18. Vanhoutte EK, Faber CG, Merkies IS, PeriNom Ssg. 196th ENMC international workshop: Outcome measures in inflammatory peripheral neuropathies 8-10 February 2013, Naarden, The Netherlands. Neuromuscular disorders : NMD. 2013;23(11):924-33.

19. Vanhoutte EK, Hermans MC, Faber CG, Gorson KC, Merkies IS, Thonnard JL, et al. Raschionale for neurologists. J Peripher Nerv Syst. 2015;20(3):260-8.

20. Lunn MP, Van den Bergh PY. Outcome measures in neuromuscular disease: is the world still flat? Journal of the peripheral nervous system : JPNS. 2015;20(3):255-9.

21. van Nes SI, Faber CG, Merkies IS. Outcome measures in immune-mediated neuropathies: the need to standardize their use and to understand the clinimetric essentials. Journal of the peripheral nervous system : JPNS. 2008;13(2):136-47.

22. Wright BD, Linacre JM. Observations are always ordinal; measurements, however, must be interval. Arch Phys Med Rehabil. 1989;70(12):857-60.

23. Hobart JC, Cano SJ, Zajicek JP, Thompson AJ. Rating scales as outcome measures for clinical trials in neurology: problems, solutions, and recommendations. The Lancet Neurology. 2007;6(12):1094-105.

24. Merbitz C, Morris J, Grip JC. Ordinal scales and foundations of misinference. Archives of physical medicine and rehabilitation. 1989;70(4):308-12.

25. Stevens SS. On the Theory of Scales of Measurement. Science. 1946;103(2684):677-80.

26. Stucki G, Daltroy L, Katz JN, Johannesson M, Liang MH. Interpretation of change scores in ordinal clinical scales and health status measures: the whole may not equal the sum of the parts. J Clin Epidemiol. 1996;49(7):711-7.

27. Magasi S, Ryan G, Revicki D, Lenderking W, Hays RD, Brod M, et al. Content validity of patientreported outcome measures: perspectives from a PROMIS meeting. Quality of life research : an 
international journal of quality of life aspects of treatment, care and rehabilitation. 2012;21(5):73946.

28. McKenna SP. Measuring patient-reported outcomes: moving beyond misplaced common sense to hard science. BMC medicine. 2011;9:86.

29. Patrick DL, Burke LB, Powers JH, Scott JA, Rock EP, Dawisha S, et al. Patient-reported outcomes to support medical product labeling claims: FDA perspective. Value in health : the journal of the International Society for Pharmacoeconomics and Outcomes Research. 2007;10 Suppl 2:S12537.

30. Green E, Yothers G, Sargent DJ. Surrogate endpoint validation: statistical elegance versus clinical relevance. Statistical methods in medical research. 2008;17(5):477-86.

31. Kemmler G, Zabernigg A, Gattringer K, Rumpold G, Giesinger J, Sperner-Unterweger B, et al. A new approach to combining clinical relevance and statistical significance for evaluation of quality of life changes in the individual patient. J Clin Epidemiol. 2010;63(2):171-9.

32. Stang A, Poole C, Kuss O. The ongoing tyranny of statistical significance testing in biomedical research. Eur J Epidemiol. 2010;25(4):225-30.

33. Terwee CB, Terluin B, Knol DL, de Vet HC. Combining clinical relevance and statistical significance for evaluating quality of life changes in the individual patient. J Clin Epidemiol. 2011;64(12):1465-7; author reply 7-8.

34. Kersten P, Kucukdeveci AA, Tennant A. The use of the Visual Analogue Scale (VAS) in rehabilitation outcomes. Journal of rehabilitation medicine. 2012;44(7):609-10.

35. Kersten P, White PJ, Tennant A. Is the pain visual analogue scale linear and responsive to change? An exploration using Rasch analysis. PLoS One. 2014;9(6):e99485.

36. Brandsma JW, Schreuders TA, Birke JA, Piefer A, Oostendorp R. Manual muscle strength testing: intraobserver and interobserver reliabilities for the intrinsic muscles of the hand. Journal of hand therapy : official journal of the American Society of Hand Therapists. 1995;8(3):185-90.

37. Cuthbert SC, Goodheart GJ, Jr. On the reliability and validity of manual muscle testing: a literature review. Chiropractic \& osteopathy. 2007;15:4.

38. Dyck PJ, Boes CJ, Mulder D, Millikan C, Windebank AJ, Dyck PJ, et al. History of standard scoring, notation, and summation of neuromuscular signs. A current survey and recommendation. Journal of the peripheral nervous system : JPNS. 2005;10(2):158-73.

39. MacAvoy MC, Green DP. Critical reappraisal of Medical Research Council muscle testing for elbow flexion. The Journal of hand surgery. 2007;32(2):149-53.

40. Merlini L. Measuring muscle strength in clinical trials. The Lancet Neurology. 2010;9(12):1146. 
General discussion and future perspectives | 107 
Appendices 
Summary

Nederlandse samenvatting

Valorisation

Dankwoord

Curriculum Vitae

List of publications 


\section{SUMMARY}

This thesis describes the analyses and development of outcome measures in inflammatory neuropathies. Here a summary of each chapter will be presented.

\section{Chapter 1}

A general introduction was given to inflammatory neuropathies and outcome measures, as well as extensively clarifying the Rasch model.

Next, the Peripheral Neuropathy outcome Measures Standardization (PeriNomS) study was introduced. The PeriNomS study originated from an unmet need for proper outcome measures in inflammatory neuropathies. This international collaborative effort between 26 neuromuscular centres consisted of a cross-sectional and a longitudinal part, for which data was collected between 2007 and 2012.

The first part of the PeriNomS study was presented by dr. Sonja I. van Nes. Her thesis addressed a variety of subjects, including normative value studies, Rasch-built outcome measures, comparative validity, reliability and responsiveness studies and an introduction into the concept of minimum clinically important difference (MCID).

The second part of the PeriNomS study was presented by dr. Els K. Vanhoutte. New outcome measures on the level of daily functioning were developed whilst also analysing their clinimetric properties. In her thesis a core set of disease specific outcome measures are presented. Also the concept of defining a responder was addressed, incorporating Rasch analysis and the MCID.

The current thesis is the third part of the PeriNomS study. It's general aim is to determine whether our outcome measures truly reflect and capture the patient's voice. This is done by analysing and developing new outcome measures through modern clinimetric methods and critically appraising existing outcome measures in inflammatory neuropathies.

\section{Chapter 2}

We analysed and compared the responsiveness of two outcome measures, the patient-reported I-RODS and the clinician-reported Inflammatory Neuropathy Cause and Treatment-Overall Neuropathy Limitation Scale (INCAT-ONLS). The responsiveness was determined by the MCID-SE method. A correlation with the EuroQoL thermometer score was done as well for both instruments. 
The I-RODS showed better responsiveness compared to the INCAT-ONLS for GBS and CIDP patients. It showed a better correlation to the EuroQoL thermometer as well which further strengths the I-RODS more closely reflecting the patient's view. In conclusion we advise the I-RODS to be used as the primary outcome measure on the activity and participation level in future studies for inflammatory neuropathies.

\section{Chapter 3}

This chapter is a critical appraisal of 'the ability to walk', a commonly used outcome measure in inflammatory neuropathy studies. We examined whether this dichotomized outcome measure truly represents overall functionality in a population of GBS, CIDP and MGUSP patients.

Overall functionality was represented by the I-RODS. Our study showed that despite having or recovering the ability to walk outside independently, most patients still showed poor general functionality. This means that even though patients recover the ability to walk, they still can have major limitations in their daily functioning even though the treatment is deemed successful. On the other hand, by limiting trial and treatments inclusions to the (dis)ability to walk, patients who have limitations in their daily functioning are unjustly excluded.

\section{Chapter 4}

We examined the correlation between the I-RODS, a patient reported outcome measure, and grip strength, a commonly used and objective metric in inflammatory neuropathies. This was done in a population of GBS, CIDP and MGUSP patients. For each patient category, a clear correlation was seen with GBS patients showing the most clear correlation.

\section{Chapter 5}

The aim of the study in this chapter was to develop a new Quality of Life (QoL) questionnaire designed for inflammatory neuropathy patients (named the 'IN-QoL') as well as fulfilling modern clinimetric standards (the Rasch model). We tested its validity by showing a good correlation with the EuroQoL thermometer (abbreviated to 'EQ-VAS' in this study). We applied the MCID-SE concept to determine responsiveness. This resulted in a 73 item-questionnaire with 2 or 3 response options, consisting of two subsets ( 55 items in the 'mental' subset, 18 items in the 'functional' subset).

Patients with GBS and CIDP showed clinically important improvement, whereas MGUSP and MMN patients did not. This was perhaps due to the more indolent nature of these illnesses and the relative short follow-up period of 1 year. 
The fact that the EQ-VAS showed a strong correlation with this extensive questionnaire, raising the question whether we should keep burdening patients with tedious and endless questionnaires rather than just asking them how they feel.

In conclusion, we would advise using the IN-QoL as well as the EQ-VAS in future studies in inflammatory neuropathies as outcome measures for quality of life.

\section{Chapter 6}

This chapter is a short review targeting the neurological community regarding the minimum clinically important difference (MCID). It offers insight on the origin and the plethora of adaptations of this concept. The main two methods on how to determine the MCID (distribution- and anchor-based) are explained as well as the pitfalls in applying the MCID. In conclusion, recommendations are given on how to apply and critically evaluate the concept of the MCID. 


\section{NEDERLANDSE SAMENVATTING}

Dit proefschrift beschrijft de analyses en ontwikkeling van uitkomstmaten bij inflammatoire neuropathieën. Hier zal een samenvatting gegeven worden over ieder hoofdstuk.

\section{Hoofdstuk 1}

Een algemene introductie betreffende inflammatoire neuropathieën en uitkomstenmaten, waarbij ook het Rasch model uitvoerig werd toegelicht.

Vervolgens werd de Peripheral Neuropathy outcome Measures Standardization (PeriNomS) studie besproken. De PeriNomS studie is ontstaan vanwege een onbeantwoorde vraag naar degelijke uitkomstmaten in inflammatoire neuropathieën. Deze internationale samenwerking tussen 26 neuromusculaire centra bestaat uit een cross-sectioneel en longitudinaal gedeelte waarvoor tussen 2007 en 2012 gegevens verzameld zijn.

Het eerste gedeelte van de PeriNomS studie is gepresenteerd door dr. Sonja I. van Nes. Haar proefschrift omvat studies naar normaalwaarden, Rasch-gebaseerde uitkomstmaten, vergelijkende studies betreffende validiteit, betrouwbaarheid en responsiviteit en een introductie over het concept van 'minimum clinically important difference' (MCID).

Het tweede gedeelte van de PeriNomS studie is gepresenteerd door dr. Els K. Vanhoutte. Hierin zijn nieuwe uitkomstmaten op het niveau van het algemeen dagelijks functioneren ontwikkeld waarbij ook gekeken is naar de klinimetrische eigenschappen van deze uitkomstmaten. In haar proefschrift wordt een basis-set van ziektespecifieke uitkomstmaten gepresenteerd. Ook wordt het concept van een 'responder' besproken, waarbij het Rasch model en het MCID concept worden meegenomen.

Dit proefschrift is het derde gedeelte van de PeriNomS studie. Het algemene doel is om te bepalen of onze huidige uitkomstmaten daadwerkelijk een goede weerspiegeling zijn van de mening van de patiënt. Dit is gedaan door het kritisch analyseren van huidige uitkomstmaten en het opstellen van nieuwe uitkomstmaten middels moderne klinimetrische methodes.

\section{Hoofdstuk 2}

We hebben de responsiviteit van twee uitkomstmaten geanalyseerd en met elkaar vergeleken, de patiënt-gerapporteerde I-RODS en de clinicus-gerapporteerde 
Inflammatory Neuropathy Cause and Treatment-Overall Neuropathy Limitation Scale (INCAT-ONLS).

De responsiviteit werd bepaald middels de MCID-SE methode. Een correlatie met de EuroQoL thermometer score werd ook opgesteld voor beide uitkomstmaten.

De I-RODS liet een betere responsiviteit zien voor patiënten met GBS en CIDP in vergelijking met de INCAT-ONLS. Ook was er een sterkere correlatie met de EuroQoL thermometer voor de I-RODS, hetgeen gezien kan worden dat deze uitkomstmaat een betere weergave is van de mening van de patiënt.

Concluderend adviseren wij om de I-RODS als primaire uitkomstmaat op het niveau van activiteit en participatie in toekomstige studies voor inflammatoire neuropathieën.

\section{Hoofdstuk 3}

Dit hoofdstuk is een kritische beschouwing over het 'vermogen om te lopen', een veelgebruikte uitkomstmaat in inflammatoire neuropathie studies.

We hebben bestudeerd of deze dichotome uitkomstmaat werkelijk algeheel functioneren weergeeft in een populatie van patiënten met GBS, CIDP en MGUSP.

Algeheel functioneren was weergegeven door de I-RODS. Onze studie toonde aan dat ondanks het behoud van of het herstel van het vermogen om te kunnen lopen, veel patiënten alsnog matig scoorden op algeheel functioneren. Dit betekent dat hoewel patiënten weer kunnen lopen, zij alsnog grote beperkingen kunnen ervaren in hun dagelijks functioneren ondanks een zogenoemde succesvolle behandeling.

Aan de andere kant, door het beperken van deelname aan trials of verkrijgen van behandeling op basis van het (on)vermogen te kunnen lopen worden patiënten, met wel beperkingen in het dagelijks functioneren, onterecht uitgesloten.

\section{Hoofdstuk 4}

Hierin werd de correlatie bepaald tussen de I-RODS, een patiënt gerapporteerde uitkomstmaat, en knijpkracht, een veelgebruikte en objectieve uitkomstmaat in inflammatoire neuropathieën. Dit werd gedaan in een populatie van patiënten met GBS, CIDP en MGUSP. Voor elke patiënten categorie werd een duidelijke correlatie gezien, waarbij patiënten met GBS de meest duidelijke correlatie vertoonden. 


\section{Hoofdstuk 5}

Het doel van de studie in dit hoofdstuk was het ontwikkelen van een nieuwe kwaliteit van leven (Quality of Life, QoL) vragenlijst gericht op inflammatoire neuropathieën (genaamd 'IN-QoL') waarbij deze ook voldeed aan de eisen van moderne klinimetrische methodes (het Rasch model). We hebben de validiteit bepaald middels het aantonen van een goede correlatie met de EuroQoL thermometer (in deze studie afgekort naar 'EQ-VAS'). Voor het bepalen van de responsiviteit hebben we het concept van de MCID-SE toegepast. Dit resulteerde in een vragenlijst bestaande uit 73 items met 2 of 3 antwoordmogelijkheden, bestaande uit twee subsets ( 55 items in een 'mentale' subset, 18 items in een 'functionele' subset).

Patiënten met GBS en CIDP toonden klinisch relevante verbetering, waarbij de MGUSP en MMN patiënten dit niet toonden. Dit is mogelijk het gevolg van het meer trage natuurlijke beloop van deze ziektebeelden en de relatief korte follow-up duur van 1 jaar.

Het feit dat de EQ-VAS een sterke correlatie vertoonde met deze nieuwe vragenlijst zorgt ervoor dat men zich kan afvragen of we patiënten moeten belasten met omslachtige en langgerekte vragenlijsten of dat we patiënten gewoon moeten vragen hoe zij zich voelen.

Concluderend adviseren wij dat zowel de IN-QoL als de EQ-VAS zouden moeten worden meegenomen in toekomstige studies in inflammatoire neuropathieën als uitkomstmaten voor kwaliteit van leven.

\section{Hoofdstuk 6}

Dit hoofdstuk is een korte review gericht op de neurologische gemeenschap betreffende de 'minimum clinically important difference' (MCID), oftewel 'het kleinst mogelijke verschil welke klinisch belangrijk is'. Het geeft inzicht in het ontstaan van en de veelvoud aan soortgelijke concepten. De twee belangrijkste methodes hoe de MCID bepaald wordt worden uitgelegd alsmede ook de valkuilen in het gebruik hiervan. Tevens worden er aanbevelingen gegeven hoe de MCID te gebruiken en deze ook kritisch te evalueren. 


\section{VALORISATION}

Valorisation is the translation of scientific knowledge to social, economic and financial value and its relevance to society.

As part of the PeriNomS study, this thesis originated from an unmet need for proper outcome measures in inflammatory neuropathies.

Inflammatory neuropathies are relative rare but severe disorders which can lead to severe impairments in daily functioning and reduced quality of life. They require expensive treatments and long-term follow-up by medical professionals, and patients are limited in fulfilling socio-economical positions in society. The disease burden for the individual patient and their care-givers is high. For inflammatory neuropathies no cure is available, only treatments that slow progression, help maintain or partially recover lost functionality.

The development of new drugs through clinical trials in these disorders is expensive and challenging due to their rarity. This is further hampered by a wide range of outcome measures used in these trials, many of which lack proper clinimetric standards. This leads to less comparability between trials, as well as risking false study results. A treatment could be falsely deemed successful or ineffective if incorrect outcome measures are used.

By improving or creating proper outcome measures to be used in clinical trials in these disorders, we can prevent misinterpretation of these trials, protecting patients from unnecessary or ineffective treatments and prevent withholding effective treatments. This will lead to better patient care, resulting in a better socio-economical position for these patients as well as reducing their dependence on medical care. By protecting patients from ineffective treatments we reduce their health care cost, also by protecting them from potential side-effects which can burden both the patient and the health care system.

Furthermore, by establishing core sets of outcome measures to be used, we ensure comparability between studies. Due to the rarity of these disorders, the ability to compare studies results and perform meta-analyses is of major importance to help draw strong and evidence based recommendations from these trials. This will result in fewer trials needed to provide quality evidence regarding potential new treatments, which will allow for research funds to be invested into other research subjects or perform follow-up studies more easily. 
Also, to be able to avoid the use of redundant or incorrect outcome measures will help decrease the burden for study participants and can lead to better patient participation in clinical trials, as the nature of these disorders requires long-term follow-up studies. This too will result in better quality evidence for new treatments, which will ultimately result in better patient care with less health care costs involved.

This thesis has resulted in further improving the much-needed outcome measures in inflammatory neuropathies as well as developing a new quality of life scale for these patients. Furthermore we have established a sound basis on how to define a responder as well as give investigators recommendations on which outcome measures they should use in inflammatory neuropathies.

These results are all part of a major international endeavour, and our results have been announced in organized international meetings and congresses as well as many publications in high-quality medical journals. These have led to changes in guidelines for international trials in inflammatory neuropathies as well as on how to evaluate our patients in daily clinical practice. 


\section{DANKWOORD}

Dit proefschrift had niet tot stand kunnen komen zonder de hulp en ondersteuning van velen. Een internationale studie zoals de PeriNomS studie is een enorme onderneming, waarbij de motivatie en passie van zowel de patiënten als de zorgverleners en onderzoekers heeft kunnen zorgen dat deze studie een succes geworden is. Mijn oprechte dank aan alle betrokken dat ik dankzij jullie harde werk en inzet dit proefschrift heb kunnen opstellen. Een aantal mensen wil ik in het bijzonder noemen.

Mijn promotor: prof. dr. C.G. Faber. Beste Karin, jouw onuitputtelijke bron van energie en capaciteit voor multitasking blijven een inspiratie. De omvang en prestaties van de neuromusculaire groep zijn met name jouw verdienste waarbij je inmiddels ook nog tot opleider bent benoemd van onze assistentengroep. Jouw daadkracht en positieve insteek zijn onmisbaar binnen beide groepen. Dank dat je mijn promotor wil zijn.

Mijn co-promotor: dr. I.S.J. Merkies. Beste Ingemar, jouw visie op uitkomstmaten en wetenschappelijk onderzoek in het algemeen zijn voor mij de grootste 'eyeopener' geweest gedurende mijn promotieonderzoek. Je hebt mij laten zien dat je altijd kritisch moet blijven, ook tegen een gevestigde (wetenschappelijke) orde. Op meerdere gebieden hebben wij overeenkomsten, maar ik ben je met name dankbaar voor de ruimte en tijd die je mij hebt gegeven, zodat ik ook op mijn eigen manier mijn proefschrift heb kunnen voltooien.

Mijn voorgangers, dr. S.I. van Nes en dr. E.K. Vanhoutte, beste Sonja en Els, heel veel dank voor al het harde werk dat jullie verricht hebben voor de PeriNomS studie. Dankzij jullie opgezette database kon ik met een goede basis aan mijn proefschrift beginnen.

Mijn opvolger, drs. M.H. Pruppers, beste Mariëlle, heel veel succes met de vervolgstudies.

Ik wil de beoordelingscommissie, bestaande uit prof. dr. R.J. Vermeulen, prof. dr. W.H. Mess, prof. dr. P.Y. van den Bergh, mw. prof. dr. A.M.C.F. Verbunt en prof. dr. I.N. van Schaik hartelijk danken voor hun tijd en kritische beoordeling van mijn proefschrift.

Ik wil alle (kinder)neurologen en klinisch neurofysiologen van het MUMC+ te Maastricht danken voor de prachtige opleidingstijd en hun bijdrage aan mijn opleiding tot (kinder)neuroloog nu ik in de laatste fase van mijn opleiding zit. Een 
speciaal woord van dank aan prof. dr. R.J. van Oostenbrugge. beste Robert, dank voor jouw bijdrage aan mijn opleiding als opleider en als praktisch ingesteld neuroloog.

De assistenten van de vakgroep Neurologie in Maastricht, jullie zijn een geweldige groep waar er naast al het harde werk ook altijd voldoende ruimte is voor ontspanning met vaak de nodige humor. Ik zal de afgelopen (en aankomende) assistent-weekenden niet snel vergeten.

De collegae van de neuromusculaire onderzoeksgroep in Maastricht, jullie ook veel dank voor de leuke tijd tijdens onze congressen. Er is in ieder geval één etentje ('I've got a taser') wat moeilijk te evenaren zal zijn.

Ook iedereen die werkzaam is op afdeling C5, de Medium Care, de polikliniek en op de KNF van het MUMC: dank voor alle gezelligheid en de fijne samenwerking.

Tevens dank aan de neurologen in het Maxima Medisch Centrum, welke mij in mijn eerste ANIOS jaren hebben begeleid en de neurologen van het Zuyderland MC te Heerlen waar ik met veel plezier mijn perifere stage heb mogen doorlopen.

Ook een woord van dank aan de vakgroep en de A(N)IOS/BAIOS Kindergeneeskunde van het Zuyderland MC, dank voor de gelegenheid om kennis te mogen maken met jullie mooie specialisme.

Mijn paranimfen, Niek en Vincent.

Beste Niek, als mijn grote broer ben je altijd wel iemand geweest om te evenaren en als het kon ook (proberen) te overtreffen. Inmiddels hebben we beide een gezin, en is het fijn om met zijn allen bij elkaar te zijn en onze kinderen samen te zien spelen. Beste Vincent, we kennen elkaar al vanaf de basisschool. Jouw moeder heeft destijds wel eens gezegd dat ze het fijn vond dat ik bij jou rust bracht, maar juist jouw onuitputtelijke optimisme (over bijna alles) is jouw grootste kracht. Jouw enthousiasme is ongeëvenaard en aanstekelijk. Ik kan altijd op je terugvallen en we hebben elkaar bijgestaan in mooie maar ook moeilijke tijden.

Ik ben trots dat jullie beiden vandaag naast me staan.

Aansluitend wil ik ook de rest van de vrienden van VC Sjortor bedanken. Sinds de middelbare school zijn we een hechte vriendengroep met ontelbare herinneringen en mooie momenten. Hoewel iedereen het inmiddels ook druk heeft met andere verplichtingen (gezin, werk), is het mooi om te zien dat als het er echt toe doet iedereen voor elkaar klaar staat. Ik ben oprecht blij dat ik jullie als vriendengroep heb. Dat we samen nog vele mooie momenten mogen beleven. 
Pap, dank voor alle steun die je mij en Niek hebt gegeven. Ondanks het verlies van Mam heb je ons een warm thuis gegeven waarbij we altijd op je terug konden en nog steeds kunnen vallen. Je werkmentaliteit en je zorgzaamheid voor anderen zijn een voorbeeld voor mij. Het is mooi om je nu ook in de rol van opa te zien genieten van je kleinkinderen.

Lieve Stijn en Esmée, iedere dag met jullie is een geschenk. Jullie zullen nog niet beseffen hoe intens wij van jullie genieten (ondanks de gebroken nachten). Ik kijk er naar uit hoe jullie ons zullen blijven verrassen naarmate jullie opgroeien.

En tenslotte mijn lieve Chantal. Wie had kunnen denken dat jouw mailtje in 2013 hiertoe zou kunnen leiden. Inmiddels hebben we samen twee prachtige kinderen waardoor ik pas echt de 'kwaliteit van leven' heb leren kennen. Dank voor al je liefde en steun tijdens het werken aan mijn proefschrift. Je bent een geweldige vriendin en een fantastische moeder! 


\section{CURRICULUM VITAE}

Tim (Thomas Hubertus Peter) Draak was born on $28^{\text {th }}$ July 1985 in Kronenberg, the Netherlands. He graduated from secondary school, VWO, at the Dendron College Horst in 2003. The same year he started his medical training at the Radboud University in Nijmegen (formerly known as Katholieke Universiteit Nijmegen). During his studies he joined research projects in ALS patients. In 2011 he graduated medical school and started working as a resident in the Neurology Department of the Maxima Medisch Centrum in Veldhoven for 2 years. In 2013 he started his specialist training in Neurology at the Maastricht University Medical Centre under the supervision of prof. dr. R. J. Van Oostenbrugge and prof. dr. C.G. Faber. During the same year, he started his $\mathrm{PhD}$ regarding outcome measures in inflammatory neuropathies as part of the Peripheral Neuropathy outcome measures Standardisation (PeriNomS) study, under the supervision of prof. dr. C.G. Faber and dr. I.S.J. Merkies. During his specialist training the exposure to pediatric neurology made him pursue the goal to become a pediatric neurologist under the supervision of prof. dr. R. J. Vermeulen. His training will finish in 2020. He is currently living in Eijsden, together with Chantal Faarts and their two children Stijn (2016) and Esmée (2018).

Tim (Thomas Hubertus Peter) Draak is geboren op 28 juli 1985 in Kronenberg. In 2003 behaalde hij zijn diploma van de middelbare school, VWO, op het Dendron College in Horst. In hetzelfde jaar begon hij zijn geneeskunde opleiding bij de Radboud Universiteit in Nijmegen (voorheen de Katholieke Universiteit Nijmegen). Tijdens zijn opleiding droeg hij bij aan onderzoeksprojecten bij ALS patiënten. In 2011 behaalde hij zijn artsdiploma en begon hij te werken als ANIOS Neurologie in het Maxima Medisch Centrum in Veldhoven gedurende 2 jaar. In 2013 begon hij aan zijn specialistische opleiding Neurologie in het Maastricht Universitair Medisch Centrum bij prof. $d r$. R. J. Van Oostenbrugge en prof. dr. C.G. Faber. In hetzelfde jaar is hij begonnen aan zijn promotieonderzoek over uitkomstmaten bij inflammatoire neuropathieën onder begeleiding van prof. dr. C.G. Faber en dr. I.S.J. Merkies. De kennismaking met de Kinderneurologie gedurende zijn specialistische opleiding hebben hem doen besluiten om de subspecialisatie Kinderneurologie te volgen onder begeleiding van prof. $d r . R . J$. Vermeulen. Zijn specialistische opleiding zal in 2020 afgerond worden. Momenteel woont hij in Eijsden, samen met Chantal Faarts en hun twee kinderen Stijn (2016) en Esmée (2018). 


\section{LIST OF PUBLICATIONS}

Draak THP, de Greef BTA, Faber CG, Merkies ISJ; PeriNomS study group. The minimum clinically important difference: which direction to take. Eur J Neurol. 2019 Jun;26(6):850-855.

Draak THP, Faber CG, Merkies ISJ, PeriNom SsG. Quality of life in inflammatory neuropathies: the IN-QoL. Journal of neurology, neurosurgery, and psychiatry. 2018;89(3):256-62.

Draak TH, Gorson KC, Vanhoutte EK, van Nes SI, van Doorn PA, Cornblath DR, et al. Does ability to walk reflect general functionality in inflammatory neuropathies? Journal of the peripheral nervous system : JPNS. 2016;21(2):74-81.

Draak TH, Gorson KC, Vanhoutte EK, van Nes SI, van Doorn PA, Cornblath DR, et al. Correlation of the patient's reported outcome Inflammatory-RODS with an objective metric in immune-mediated neuropathies. European journal of neurology. 2016;23(7):1248-53.

Vanhoutte EK, Draak TH, Gorson KC, van Nes SI, Hoeijmakers JG, Van der Pol WL, et al. Impairment measures versus inflammatory RODS in GBS and CIDP: a responsiveness comparison. Journal of the peripheral nervous system : JPNS. 2015;20(3):289-95.

Pruppers MH, Draak TH, Vanhoutte EK, Van der Pol WL, Gorson KC, Leger JM, et al. Outcome measures in MMN revisited: further improvement needed. Journal of the peripheral nervous system: JPNS. 2015;20(3):306-18.

Draak TH, Vanhoutte EK, van Nes SI, Gorson KC, Van der Pol WL, Notermans NC, et al. Comparing the NIS vs. MRC and INCAT sensory scale through Rasch analyses. Journal of the peripheral nervous system : JPNS. 2015;20(3):277-88.

Draak TH, Pruppers MH, van Nes SI, Vanhoutte EK, Bakkers M, Gorson KC, et al. Grip strength comparison in immune-mediated neuropathies: Vigorimeter vs. Jamar. Journal of the peripheral nervous system: JPNS. 2015;20(3):269-76.

Draak TH, Vanhoutte EK, van Nes SI, Gorson KC, Van der Pol WL, Notermans $\mathrm{NC}$, et al. Changing outcome in inflammatory neuropathies: Rasch-comparative responsiveness. Neurology. 2014;83(23):2124-32. 
Broen M, Draak T, Riedl RG, Weber WE. Diffuse large B-cell lymphoma of the cauda equina. BMJ case reports. 2014;2014.

Verstraete E, Veldink JH, Huisman MH, Draak T, Uijtendaal EV, van der Kooi AJ, et al. Lithium lacks effect on survival in amyotrophic lateral sclerosis: a phase IIb randomised sequential trial. Journal of neurology, neurosurgery, and psychiatry. 2012;83(5):557-64. 
124 
